\title{
THREE CATHOLIC CONGREGATIONS IN A NINETEENTH-CENTURY CANADIAN CITY: \\ PROVIDING SOCIAL SERVICES, CLAIMING SPACE FOR WOMEN IN KINGSTON, 1841-1874
}

by

Theresa LeBane

A thesis submitted to the Faculty of Graduate and Postdoctoral Affairs in partial fulfillment of the requirements for the degree of

Master of Arts

in

History

Department of History

Carleton University

Ottawa, Canada

August 13, 2018

(C) Copyright, 2018, Theresa LeBane 


\begin{abstract}
This thesis examines three Roman Catholic congregations of women, the Congrégation de Notre-Dame, the Religious Hospitallers of Saint Joseph, and the Sisters of Providence, and the services they provided between 1841 and 1874 in Kingston, Canada West and Ontario. A careful reading of the personal written records of Kingston's women religious, informed by gender analysis, reveals their role in the building of hospitals, schools, and orphanages, and their dedication to bettering the lives of the disadvantaged and indigent. These contributions aligned with the larger goals of the provincial government and ecclesiastical authorities. Kingston's women religious established multiple institutions, faced unspeakable risks to their health, and overcame overt anti-Catholicism in carrying out and expanding the city's social services.
\end{abstract}




\section{Acknowledgements}

I am indebted to many people for their help, support and encouragement. I could not have finished writing my thesis without the support of family, friends, classmates, and colleagues.

I want to express my appreciation to the faculty and staff of the History Department. I particularly want to thank Joan White for all her assistance. I also thank Dr. Norman Hillmer for his words of wisdom, as well as Mallory Pierce, Elise Bigley, and Francesca Brzezicki for their friendship and for reading my early drafts.

Archivists Veronica Stienburg of the Sisters of Providence of St. Vincent de Paul, Rodney Carter of the Religious Hospitallers of Saint Joseph, and Marie-Josée Morin of the Congrégation de Notre-Dame provided invaluable guidance during my years of research. I would also like to thank Father Dan Ryan for providing access to the Archives of the Archdiocese of Kingston.

Special thanks to the Sisters of the Congrégation de Notre-Dame, Religious Hospitallers of Saint Joseph, and Sisters of Providence of St. Vincent de Paul.

My deepest gratitude I reserve for my supervisor, Dr. Susan Whitney, for her unwavering support, endless encouragement, and the countless hours spent discussing and reviewing my chapters.

Finally, I dedicate this thesis with love to my long-suffering and ever patient family. 


\section{TABLE OF CONTENTS}

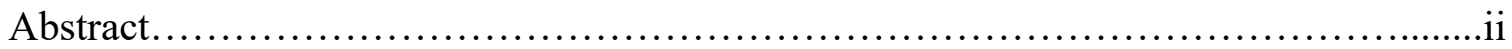

Acknowledgements.......................................................

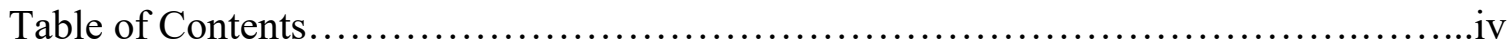

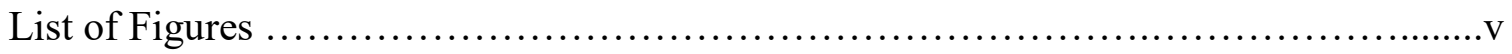

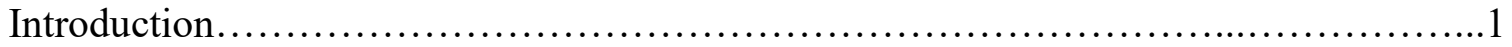

Chapter I: Whose Vision Would Prevail?: Faith and State Intertwined...................15

Chapter II: Vowed Women Religious and Their Work ..............................54

Chapter III: Obstacles in Nineteenth-Century Ontario, Real and Imagined..............80

Conclusion............................................................ 114

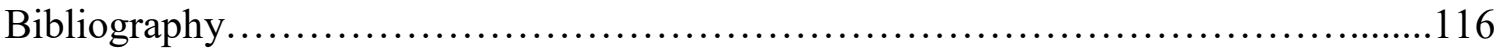


Figures

page

Figure 1.1 Notice for establishing Hôtel-Dieu Hospital, Kingston.....................

Figure 2.1 Sr. Claire Latour's 'Act of Protestation' ...............................62

Figure 2.2 Sr. Emélie Barbarie's ‘Act of Protestation'...............................63

Figure 2.3 Lucy McDougal's record of entrance to the Kingston Hôtel-Dieu..............64

Figure 2.4 Caring for typhus victims, Kingston waterfront, $1847 \ldots \ldots \ldots \ldots \ldots \ldots \ldots . \ldots . \ldots \ldots$

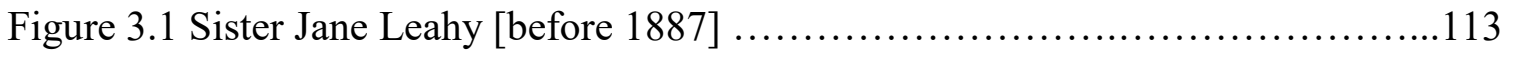




\section{Introduction}

If a person had been walking down Brock Street in Kingston, Canada West, on a dark December evening in 1847, she might have chanced upon a young postulant flying out the doors of the Religious Hospitallers of Saint Joseph's monastery. The chimney of the men's hospital ward was on fire and, dispatched to get help, she ran straight across the street to the Catholic secondary school, college, and seminary, Regiopolis College. ${ }^{1}$ She rounded up a group of young men and they hurried back together. The hospital's new wing had been erected over the past year and was still under construction. The men climbed out the highest window and, after clambering onto the roof and the hospital's unfinished third floor, managed to douse the fire. Taking further precautions, Father Chrisholm shoved his head through a hole in the ceiling to check for sparks in the garret. Without dormer windows, a ladder, or bench, he was forced to climb up the linen shelves until they collapsed beneath him. Before he and the linen tumbled down, however, he managed to ensure that there were no stray embers. It had already been a long year of crises and, exhausted from their exertions battling the typhus epidemic, the nuns were grateful that their patients, staff, and buildings were safe (Fig. 1.1). ${ }^{2}$

Montréal's Religious Hospitallers of Saint Joseph, better known as the Hôtel-Dieu nuns, had arrived in Kingston in 1845 to establish a monastery and hospital at the request of Bishops Gaulin and Phelan. They were not the first group of women religious in the city. The Sisters of the Congrégation de Notre-Dame had been invited by Bishop Gaulin

\footnotetext{
${ }^{1}$ Margaret Angus, The Old Stones of Kingston: Its Buildings Before 1867 (Toronto: University of Toronto Press, 1966), 48-9.

2 "Typed Transcript of the Annals (in English) - Translation of the Annals of our House of Kingston, 1845 - to -" [translated entries dated 3 February 1891], The Annals and Chronicles of St. Joseph Province, 84.113, St. Joseph Region Archives of the Religious Hospitallers of St. Joseph, Kingston [hereafter RHSJ-SJR Archives], 15-16.
} 


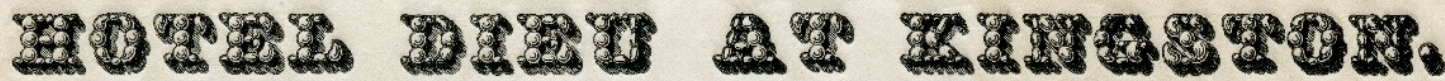

A Large and Commodious Wing, Three Stories high, is to be erected immediately, by means of Surscrirtrons, and the Donations of the charitable and humane, for the relief and benefit of the

\section{DESTITUTE SICK OF ALL DENOMINATIONS,}

Upon a Lot of land adjoining the present Hospital, granted by the Executors of the late Right Reverend Bishop MolDonexx, for that purpose.

Much praise is due to Captain Hunter, the President of the Sailors' Society in this City, for his zeal and generosity in first promoting this useful and Philanthropic undertaking, for the use of Sick and Distressed Sailors, and others. The sum of at least Four Thousand Five Hundred Dollars being required to complete this Building, the Clergy of the Dircese of Kingston, and all the Captains of Steamboats, Vessels, Barges, \&c., and all the Foremen of Public Works, are therefore earnestly requested to act as Collectors and Pursers, in their respective departments, and to remit the amount collected for the purpose, with the names of the Subscribers, to the Right Rev. Bishop Preuan, or to any of the Catholic Clergy of Kingston.

The amount of Subscriptions already obtained is as follows, viz :-
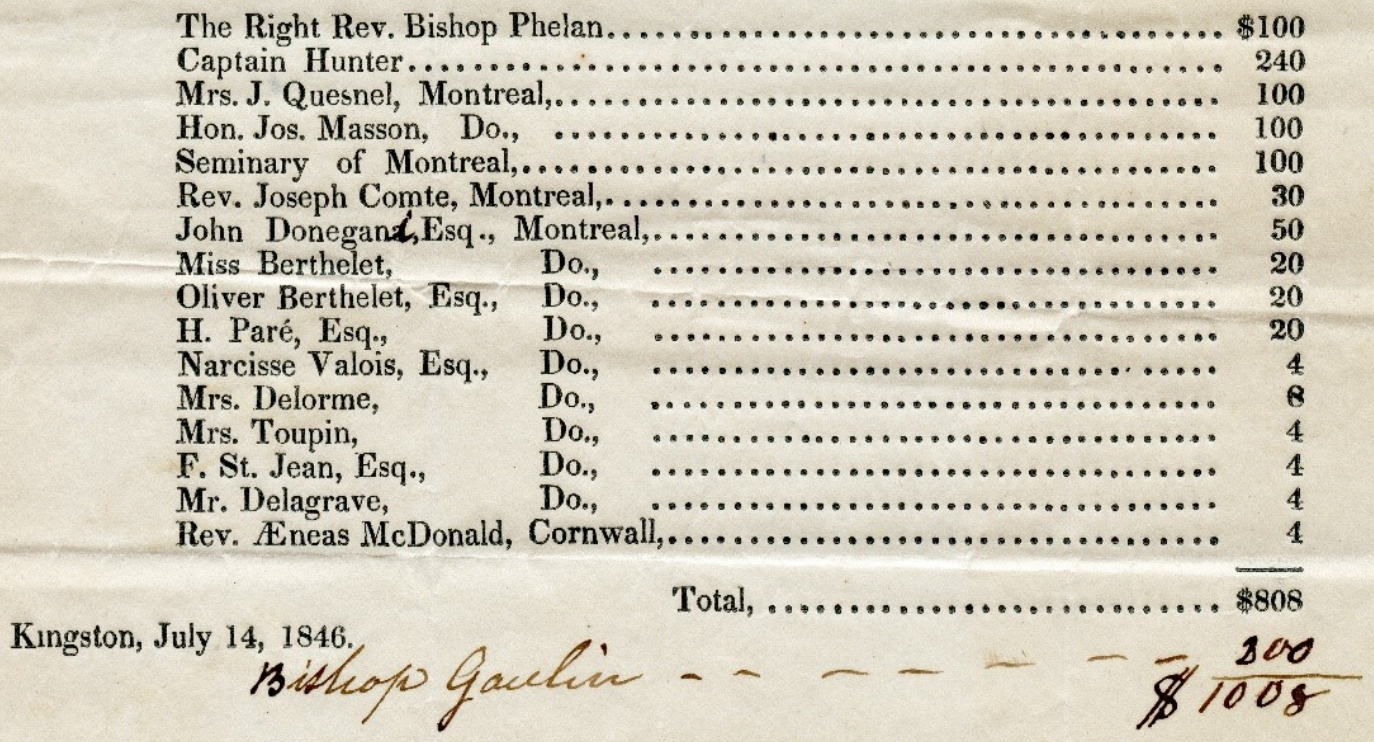

Fig. 1.1 List of subscribers for the new wing of the Hôtel-Dieu Hospital, Kingston, dated July 14, 1846. Archives of the Religious Hospitallers of St. Joseph, St. Joseph Region, Kingston, 84.5/03.007. 
to open a school for girls and had arrived in November of 1841. By 1860, Kingston's subsequent bishop, Edward John Horan, required more sisters to care for the varied needs of the dispossessed. For his diocese, Horan requested Émilie Tavernier Gamelin's Sisters of Providence, founded less than two decades previously in Montréal. Four sisters took up residence in December of 1861. Legally, they were the Sisters of Charity of the House of Providence, Kingston, but commonly known as the Sisters of Providence. ${ }^{3}$

This thesis examines three Roman Catholic religious institutes of consecrated women, ${ }^{4}$ the Congrégation de Notre-Dame, the Religious Hospitallers of Saint Joseph, and the Sisters of Providence, who established educational and charitable institutions in mid-nineteenth-century Kingston, Canada West. ${ }^{5}$ This study will explore the type of work the sisters' performed, how their religious missions intersected with the aims of both the provincial government and ecclesiastical authorities, and how these women religious encountered, and were affected by, obstacles, both real and imagined, between the years 1841 and 1874. These were unique years of nation building in English Canada, and the Catholic Church was determined to play a major part in Canada West's construction.

\footnotetext{
${ }^{3}$ The congregation legally changed its name to the Sisters of Providence of St. Vincent de Paul on May 15, 1952 , by which name it is currently known.

${ }^{4}$ For the purposes of clarity and consistency, 'religious institutes,' that is, groups of canonically approved women religious, will be referred to as 'congregations' throughout this thesis. Technically, the Religious Hospitallers of Saint Joseph were cloistered nuns, and the Notre-Dame and Sisters of Providence, because their ministry meant they were active in the world, were considered sisters. Again, for the sake of clarity, they will be grouped together as 'sisters' or 'women religious' unless the discussion centers on the HôtelDieu nuns. In the nineteenth-century, confusion often reigned among the public, and all female religious were referred to as either nuns or sisters, and their homes called convents, nunneries, or monasteries. For a explanation of technical terms used to describe religious life in the Roman Catholic Church, see Michel Thériault, The Institutes of Consecrated Life in Canada From the Beginning of New France up to the Present: Historical Notes and References (Ottawa: National Library of Canada, 1980), 13-44. ${ }^{5}$ Between 1841 and 1867, Canada West formed one half of the Province of Canada, which until 1840 had been Upper Canada. In 1867, Canada West became the Province of Ontario.
} 
Catholic sisters helped shape the mix of public and private charitable aid broadly available during this period in Canada's history. ${ }^{6}$

In 1841, Kingston was named the new capital of Canada West, and the city's future appeared bright. The shine quickly faded. The following decades were marked by decline: the loss of the designation as capital in 1844 , the weakening shipping industry with the emergence of the railroad, and the loss of residents to Toronto as locals moved in search of job opportunities. ${ }^{7}$ Coupled with a lack of immigration, growth slowed. In these same years, however, Catholic women religious made a lasting impact on the City of Kingston through their institution building. Sisters and nuns responded to social needs on several fronts: education, healthcare, and a variety of related services. They cared for orphaned children and the elderly, provided financial support to the most economically vulnerable, and visited incarcerated women. Their success can be partly attributed to the generosity of their social networks, which were interwoven with other religious congregations, friends, family, benefactors, local community members, Catholic priests and prelates, and transnational colleagues. The individuals connected to these religious congregations and the City of Kingston provided the financial assistance that enabled the sisters' charitable endeavors when their income was insufficient.

\footnotetext{
${ }^{6}$ Richard B. Splane, Social Welfare in Ontario, 1791-1893: A Study of Public Welfare Administration (Toronto: University of Toronto Press, 1965), 31; Lynn Marks, "Indigent Committees and Ladies Benevolent Societies: Intersections of Private and Public Poor Relief in Late Nineteenth Century Small Town Ontario," Studies in Political Economy 47 (Summer 1995): 61-87; Leo Johnson, "The Political Economy of Ontario Women in the Nineteenth Century," in Women at Work: Ontario 1850-1930, ed. Janice Acton, Penny Goldsmith, and Bonnie Shepard (Toronto: Canadian Women's Educational Press, 1974), 18-19; Edgar-André Montigny, "Families, Institutions, and the State in Late-Nineteenth Century Ontario," in Ontario since Confederation: A Reader, ed. Edgar-André Montigny and Lori Chambers (Toronto: University of Toronto Press, 2000), 74-93.

${ }^{7}$ J.D. Livermore, "The Orange Order and the Election of 1861 in Kingston," in To Preserve \& Defend: Essays on Kingston in the Nineteenth Century, ed. Gerald Tulchinsky (Montreal: McGill-Queen's University Press, 1976), 248-49.
} 
Yet, Catholic women religious earned their own income, fundraised, and went on 'begging tours.' The Church's evangelical mission provided sisters admission into public spaces usually perceived as morally suspect for respectable women. It was common practice for sisters to go door-to-door on 'begging tours' in unknown town and cities, sometimes for weeks at a time, collecting money and goods to aid their charitable work. Had other "respectable" women engaged in similar endeavours, they would have been declared vagrants. Empowered, intrepid, and hardworking, sisters affected societal change and were equally affected by their environment and society. Religious life offered other opportunities to nineteenth-century Ontario women. Sisters avoided unhappy marriages with little chance of annulment or divorce, the uncertainties of childbirth, the need to care for aging parents, or being shuttled between relatives. ${ }^{8}$ At a time when less than $10 \%$ of English Canadian women remained single, a woman's ceremonial entrance into the novitiate signaled the beginning of a spiritual union with Jesus Christ, and an attendant boost in social standing among Catholics. ${ }^{9}$

The work performed by married, single, and widowed women in mid-nineteenthcentury Ontario was diverse, but generally badly paid and often unrecognized. Women were employed as washerwomen, charwomen, domestic servants, dressmakers, seamstresses, milliners, and teachers. They also worked caring for children, and sick or

\footnotetext{
${ }^{8}$ Women who wanted their marriages dissolved by the Catholic Church, required an annulment, which was possible if there was evidence of bigamy or an unfulfilled marriage contract. See Marcel Martel, Canada the Good: A Short History of Vice Since 1500 (Waterloo, Ontario: Wilfrid Laurier University Press, 2014), 36-7. Women who preferred to go through the secular courts could attempt a divorce, but royal assent was required, and the first divorce granted in Upper Canada was in Kingston in 1840. Between 1867 and 1907, only 431 divorces were recorded in Canada. See Elizabeth Abbott, A History of Marriage (Toronto: Penguin Canada, 2010), 205-6, 228.

${ }^{9}$ Peter W. Ward, Courtship, Love and Marriage in Nineteenth-Century English Canada (Montréal: McGillQueen's University Press, 1990), 51. English Canadians settled in Ontario in the second half of the nineteenth-century saw a marked decrease in the number of marriages and marital fertility, and a corresponding increase of single women.
} 
elderly relatives, producing cloth, doing farm labour, cooking, and providing hospitality in boarding houses or inns, even if these jobs were unpaid and not captured in the 1851 census. ${ }^{10}$ Much changed in Ontario following Confederation, including a broad shift towards industrial manufacturing and new paid employment opportunities for women. ${ }^{11}$ Nursing and teaching evolved into largely female professions in the late nineteenthcentury, and the professionalization of paid social work, also a largely female profession, followed in the early twentieth-century. ${ }^{12}$

\footnotetext{
${ }^{10}$ Marjorie Griffin Cohen, Women's Work, Markets, and Economic Development in Nineteenth-Century Ontario (Toronto: University of Toronto Press, 1988), 25-27; R. Marvin McInnis, "Women, Work, and Childbearing: Ontario in the Second Half of the Nineteenth-Century," Social History 24, no. 48 (November 1991): 248-54, especially 252-53; Nancy Christie, “The Plague of Servants": Female Household Labour and the Making of Classes in Upper Canada," in Transatlantic Subjects: Ideas, Institutions, and Social Experience in Post-Revolutionary British North America, ed. Nancy Christie (Montreal: McGill-Queen's University Press, 2008), 83-132; Margaret Derry, "Patterns of Gendered Labour and the Development of Ontario Agriculture," in Ontario since Confederation: A Reader, ed. Edgar-André Montigny and Lori Chambers (Toronto: University of Toronto Press, 2000), 3-15; Bettina Bradbury, "The Home as Workplace," in Labouring Lives: Work and Workers in Nineteenth-Century Ontario, ed. Paul Craven (Toronto: University of Toronto Press, 1995), 412-78; Elizabeth Ritchie, "Cows, Sheep \& Scots: Livestock and Immigrant Strategies in Rural Upper Canada, 1814-1851," Ontario History 109, no. 1 (Spring 2017): 16-19; Shirley J. Yee, "Gender Ideology and Black Women as Community-Builders in Ontario, 1850-70," Canadian Historical Review 75, no. 1 (March 1994): 53-73. For a discussion of women's employment in Upper Canada, see Jane Errington, Wives and Mothers, Schoolmistresses and Scullery Maids: Working Women in Upper Canada, 1790-1840 (Montreal; Kingston: McGill-Queen's University Press, 1995); Women and their Work in Upper Canada (Ottawa: Canadian Historical Association, 2006). For a discussion of women's employment in nineteenth-century Ireland, which was similar to women's experiences in Canada West, see Maria Luddy, Women and Philanthropy in Nineteenth-Century Ireland (Cambridge, England; New York, NY, USA: Cambridge University Press, 1995), 9-13.

${ }^{11}$ Cohen, Women's Work, 24, 45. J.M.S. Careless, "Some Aspects of Urbanization in Nineteenth-Century Ontario," in Aspects of Nineteenth-Century Ontario: Essays Presented to James J. Talman, ed. F.H. Armstrong, H.A. Stevenson, and J.D. Wilson (Toronto: University of Toronto Press, 1974), 71; McInnis, "Women, Work, and Childbearing," 252-253; Bryan D. Palmer, Working-Class Experience: The Rise and Reconstitution of Canadian Labour, 1800-1980 (Toronto: Butterworths, 1983), 91-118; Craig Heron, "Factory Work," in Labouring Lives: Work and Workers in Nineteenth-Century Ontario, ed. Paul Craven (Toronto: University of Toronto Press, 1995), 479-594; Eric W. Sager, "The Transformation of the Canadian Domestic Servant, 1871-1931," Social Science History 31, no. 4 (Winter 2007): 509-37. Legal changes to women's property rights also enabled more women to run businesses in the nineteenth-century. See Peter Baskerville, A Silent Revolution? Gender and Wealth in English Canada, 1860-1930 (Montreal and Kingston: McGill-Queen's University Press, 2008).

${ }^{12}$ Marta Danylewycz, Beth Light, and Alison Prentice, "The Evolution of the Sexual Division of Labour in Teaching: A Nineteenth-Century Ontario and Quebec Case Study," Social History 16, no. 31 (May 1983): 81-109; Ruth A. Frager, Discounted Labour: Women Workers in Canada, 1870-1939 (Toronto: University of Toronto Press, 2005), 54-62; Clarke A. Chambers, "Women in the Creation of the Profession of Social Work," Social Service Review 60, no. 1 (March 1986): 1-33; Michael Holosko and Donald R. Leslie, "Is Social Work a Profession? The Canadian Response," Research on Social Work Practice 11, no. 2 (March 2001): 201-9; Carol T. Baines, "The Professions and an Ethic of Care," in Women's Caring: Feminist
} 
Although the retrospective lens of women's history allows us to appreciate that Roman Catholic sisters and nuns were at the forefront of women's professions in nineteenth-century Ontario, the period's virulent anti-Catholic literature depicted vowed women religious "as either half-imbecile, or wasting their lives in useless and frivolous employments." ${ }^{\prime 3}$ Sisters were condemned for living 'unnaturally' outside the domestic sphere and protective guidance of a husband. Without husbands and children, the thinking went, sisters' lives were disordered. Celibate priests were further depicted as unable to control their sexual urges and, instead of praising women for their chastity as was the norm in other contexts, vowed religious were held out as objects of suspicion. For many non-Catholics, the Church's approach to sexuality and the convent's closed doors provoked curiosity and, at times, outright hostility. ${ }^{14}$

In her essay about Protestantism in mid-nineteenth century Brantford Ontario, Marguerite Van Die suggests: "Nineteenth-century central Canada offers a particularly interesting field for exploring the extent to which religious belief and practice acted as a bridge between public and private life for women." ${ }^{15}$ Die argues that "to do justice to women's influence on nineteenth-century life outside the home, the traditional distinction between the private female domestic sphere and the public male sphere of "work" needs to be redefined to include the public locus of the church."16 This thesis demonstrates how,

Perspectives on Social Welfare, ed. Carol T. Baines, Patricia M. Evans and Sheila M. Neysmith (Toronto: McClelland \& Stewart, 1991), 36-72, especially 37.

${ }^{13}$ M.F. Cusack, Life of Daniel O'Connell, The Liberator: His Times--Political, Social and Religious (New York; Montreal: D. \& J. Sadlier, 1872), xxxviii, n3.

${ }^{14}$ One moral theologian has stated the Church has a history of being "profoundly ambivalent towards human sexuality." See John Mahoney, The Making or Moral Theology: A Study of the Roman Catholic Tradition (Oxford: Claredon Press, 1987), 33.

${ }^{15}$ Marguerite Van Die, "Revisiting 'Separate Spheres': Women, Religion, and the Family in Mid-Victorian Brantford, Ontario" in Households of Faith: Family, Gender and Community in Canada, 1760-1969, ed. Nancy Christie (Montréal, Que.: McGill-Queen's University Press, 2002), 236.

${ }^{16}$ Ibid., 256. 
through their labours, religious sisters conducted their lives far more in the male public sphere than in the traditionally domestic, and private, female sphere. Numerous scholars have argued that the concept of 'separate spheres' and the gendered private-public dichotomy set out by early historians of women is an oversimplification. ${ }^{17}$ In the case of sisters, they used their spiritual and temporal works to interact with men in public spaces. This would not have been deemed respectable for secular women. Moreover, Catholic sisters and nuns were always able to fall back on their vows and the male-led hierarchal structure of the Catholic Church to claim respectability. Through their labour and identity as vowed religious, Kingston's Catholic sisters and nuns acted as a bridge between the public and private.

This study will explore the opportunities sisters seized on to improve the Kingston diocese and the local community, and illustrate how they changed Kingston. This study extends beyond the dominant themes of the scholarly literature in asking how these congregations of sisters established respected and respectable institutions administrated entirely by women, and how through their work they contributed to Kingston's social services, furthered politico-societal goals, and moderated anti-Catholic sentiments.

\section{Literature Review}

Women's history in Ontario has developed considerably since the $1980 \mathrm{~s},{ }^{18}$ and there has been an increase in scholarship about nuns. Initially, feminist historians were

\footnotetext{
${ }^{17}$ For example, see Robert B. Shoemaker, Gender in English Society 1650-1850: The Emergence of Separate Spheres? (London: Routledge, 2014). For an excellent history of 'separate spheres' in Upper Canada, see Jane Errington, Wives and Mothers, Schoolmistresses, and Scullery Maids: Working Women in Upper Canada, 1790-1840 (Montreal; Buffalo: McGill-Queen's University Press, 1995).

${ }^{18}$ For example, see Catherine Carstairs and Nancy Janovicek, eds., Feminist History in Canada: New Essays on Women, Gender, Work, and Nation (Vancouver: University of British Columbia Press, 2013).
} 
mainly concerned with restoring nuns to the historical record. ${ }^{19}$ More recently, Jan Noel, also a Canadian historian of New France, explained another shift in scholarship:

"Feminists have been studying nuns in recent decades, drawn to the possibilities that these well-organized, financially viable communities offered for feminine self-expression and leadership." ${ }^{20}$ From there, historians traced the history of individual religious congregations and sisters. Elizabeth Rapley, also a Canadian historian of seventeenth and eighteenth-century French women religious, explains that, "It was only in the later twentieth century that historians began to supply the syntheses that treat religious women as members of an identifiable countrywide group, sharing many of the same ideals, objectives, and problems." ${ }^{21}$ More recently, in the past two decades, regional, global, and transnational histories of nuns have been undertaken, including thematic histories tracing sisters' clothing and work. ${ }^{22}$

Several scholarly studies have examined the contribution Canadian Catholic sisters made to the formal education of young women and children through private and parochial schooling, Canadian healthcare, and the establishment of social services in Canada. In her ground-breaking work, Taking the Veil: An Alternative to Marriage, Motherhood and Spinsterhood in Quebec, 1840-1920 (1987), Marta Danylewycz argued

\footnotetext{
${ }^{19}$ Carol Coburn, "An Overview of the Historiography of Women Religious: A Twenty-five Year Retrospective," U.S. Catholic Historian (Winter 2004): 1-26.

${ }^{20}$ Jan Noël, review of The Congrégation de Notre-Dame, Superiors, and the Paradox of Power, 16931796, by Colleen Gray, The Canadian Historical Review 91, no. 1 (March 2010): 121.

${ }^{21}$ Elizabeth Rapley, A Social History of the Cloister: Daily Life in the Teaching Monasteries of the Old Regime (Montreal, Que.: McGill-Queen's University Press, 2001), 5.

22 Jo Ann Kay McNamara, Sisters in Arms: Catholic Nuns through Two Millennia (Cambridge, Mass.: Harvard University Press, 1996); Anne O’Brien, "Catholic Nuns in Transnational Mission, 1528-2015," Journal of Global History 11, no. 3 (November 2016): 387-408. For a history of sisters' clothing, see Elizabeth Kuhns, The Habit: A History of the Clothing of Catholic Nuns (New York: Image Books, 2003; New York: Doubleday, 2005). Multiple histories have been written about sisters' work. For just one example, see Rebecca Rogers, From the Salon to the Schoolroom: Educating Bourgeois Girls in Nineteenth-Century France (University Park, Pa.: Pennsylvania State University Press, 2005).
} 
that convent life, as seen through an analysis of two congregations of Québéc sisters, the Congrégation de Notre-Dame and the Sisters of Misericorde, was a viable option for ambitious young women seeking a life outside of the limited opportunities available to secular women. ${ }^{23}$ Danylewycz investigated the ways in which women responded to their roles as Catholic sisters and why their work was not valued in comparison to men's work in nineteenth-century Québec. Her decision to study these two congregations was partly determined by access to the convent's archives, and available census data from provincial and national records. ${ }^{24}$

In her multiple studies of vowed women religious, Elizabeth Smyth has written extensively about the influence of sisters and nuns on Canada's education systems in Ontario and Québec. In "World Within Worlds: Canadian Women Religious, International Connections, Ecclesiastical Webs and the Secular State,” an essay published in 2014, Smyth illustrated how sisters ascended to their positions running (female) singlesex institutions, the importance of their transnational social networks, and their heavy involvement in Canada's emerging social services, particularly education. ${ }^{25}$ Smyth's scholarship consistently represents sisters as pioneers in the professionalization of women's work. ${ }^{26}$ In The Congrégation de Notre-Dame, Superiors, and the Paradox of

\footnotetext{
${ }^{23}$ Marta Danylewycz, Taking the Veil: An Alternative to Marriage, Motherhood and Spinsterhood in Quebec, 1840-1920, eds., Paul-Andre Linteau, Alison Prentice, and William Westfall (Toronto: McClelland \& Stewart, 1987).

${ }^{24}$ Danylewcyz, Taking the Veil, 18.

${ }^{25}$ Elizabeth Smyth, "World Within Worlds: Canadian Women Religious, International Connections, Ecclesiastical Webs and the Secular State," in Women Educators, Leaders and Activists: Educational Lives and Networks 1900-1960, ed. Tanya Fitzgerald and Elizabeth M. Smyth (London: Palgrave MacMillan, 2014), 41-57.

${ }^{26}$ Elizabeth Smyth, "Professionalization Among the Professed: The Case of Roman Catholic Religious," in Challenging Professions: Historical and Contemporary Perspectives on Women's Professional Work, ed. Elizabeth Smyth, Sandra Acker, Paula Bourne and Alison Prentice (Toronto, University of Toronto Press: 1999), 234-54.
} 
Power, 1693-1796 (2007), Colleen Gray explored the power dynamics of the

Congrégation de Notre-Dame during the eighteenth-century. She pointed out how mother superiors were invested with power over their sisters, but their power coexisted with subservience to bishops. Through her analysis of the Montréal Congrégation de NotreDame, Gray determined that the sisters were empowered through their structured religious life, despite the restrictive conditions their bishop placed on them, and that this enabled them to maintain their commitment to serve the public. ${ }^{27}$ Imbalanced power relations between religious and bishops is neither new nor surprising to historians, and a significant secondary literature exists on the subject. ${ }^{28}$ In her 2010 article, "Who Counts and Why? Nuns, Work, and the Census of Canada, 1871-2001," Heidi MacDonald contributed significant research about the impact of Canadian sisters' work, analyzing Canadian census data, and asking why women religious were omitted from census records. Her research has furthered our understanding of the ways sisters' work was often devalued and rendered invisible. ${ }^{29}$

Unlike in France, Ireland and the United States, an in-depth study of Canadian Catholic nuns and sisters has yet to be written. ${ }^{30}$ Possibly the most important overview of

\footnotetext{
${ }^{27}$ Colleen Gray, The Congrégation de Notre-Dame, Superiors, and the Paradox of Power, 1693-1796. (Montreal: McGill-Queen's University Press, 2007).

${ }^{28}$ For example, see Morrow, Persons of Colour and Religious at the Same Time, 179-205; Leslie L. Liedel, "Indomitable Nuns and an Unruly Bishop: Property Rights and the Grey Nuns' Defense Against the Arbitrary Use of Diocesan Power in Nineteenth-Century Cleveland," The Catholic Historical Review 86, 3 (July 2000): 459-79.

${ }^{29}$ Heidi MacDonald, "Who Counts and Why? Nuns, Work, and the Census of Canada, 1871-2001," Social History 86 (November 2010): 369-91.

${ }^{30}$ Caitriona Cleare, Nuns in Nineteenth-Century Ireland (Washington, D.C.: Gill., 1987); Mary Peckham Magray, The Transforming Power of the Nuns: Women, Religion, and Cultural Change in Ireland, 17501900 (New York: Oxford University Press, 1998); John J. Fialka, Sisters: Catholic Nuns and the Making of America (New York: St. Martin's Press, 2003); Margaret McGuinness, Called to Serve: A History of Nuns in America (New York: New York University Press, 2013); Bernadette McCauley, "Nuns' Stories: Writing the History of Women Religious in the United States," American Catholic Studies 125, no. 4 (Winter 2014): 51-68.
} 
women religious in Canada is Smyth's 2007 edited collection of essays, Changing Habits: Women Religious in Canada. ${ }^{31}$ Although there have been several studies of specific ethnic communities of Catholic sisters in nineteenth-century America, ${ }^{32}$ as well as a number of studies that have examined how nuns have influenced American culture, ${ }^{33}$ these topics have not yet been addressed in any Canadian historical studies.

That said, there are useful studies that tell part of the story. Terence J. Fay has written an excellent historical overview of Canadian Catholics, ${ }^{34}$ which includes Catholic sisters, and there is an abundance of scholarly and pious congregational histories of Canadian sisters. ${ }^{35}$ Nancy McMahon has written about the Religious Hospitallers of Saint Joseph and Kingston's outbreak of typhus in the 1840s, (Sister) Calista Begnal about the Congrégation de Notre-Dame in nineteenth-century Kingston, and Elizabeth Smyth about two sisters in leadership roles with the Sisters of Providence of St. Vincent de Paul in the nineteenth-century. ${ }^{36}$ In addition, commissioned hagiographies of Kingston's Catholic

\footnotetext{
${ }^{31}$ Elizabeth Smyth, ed., Changing Habits: Women Religious in Canada (Ottawa: Novalis, 2007).

${ }^{32}$ Diane Batts Morrow, Persons of Color and Religious at the Same Time: The Oblate Sisters of Providence, 1828-1860 (Chapel Hill : University of North Carolina Press, 2002); Shannen Dee Williams, "Forgotten Habits, Lost Vocations: Black Nuns, Contested Memories, and the $19^{\text {th }}$ Century Struggle to Desegregate U.S. Religious Life," Journal of African American History, 101 (Summer 2016): 231-60; "The Color of Christ's Brides," American Catholic Studies, 127 (Fall 2016): 14-21; Maureen Fitzgerald, Habits of Compassion: Irish-Catholic Nuns and the Origins of New York's Welfare System, 1830-1920 (Urbana, Ill.: University of Illinois Press, 2006).

${ }^{33}$ Rebecca Sullivan, Visual Habits: Nuns, Feminism, and American Postwar Popular Culture (Toronto: University of Toronto Press, 2005); Carol K. Coburn and Martha Smith, Spirited Lives: How Nuns Shaped Catholic Culture and American Life, 1836-1920 (Chapel Hill: University of North Carolina Press, 1999); Brian E. Titley, Into Silence and Servitude: How American Girls Became Nuns, 19451965 (Montreal; Kingston: McGill-Queen's University Press, 2017).

${ }^{34}$ Terence J. Fay, A History of Canadian Catholics: Gallicanism, Romanism, and Canadianism (Montreal \& Kingston: McGill-Queen's University Press, 2002).

${ }^{35}$ These are too numerous to list, but almost every Canadian congregation of women religious has commissioned a history.

${ }^{36}$ Nancy McMahon, "Les Religieuses Hospitalières de Saint Joseph and the Typhus Epidemic, Kingston, 1847-1848," CCHA, Historical Studies 58 (1991): 41-55; Sister Calista Begnal, C.N.D, "Sisters of the Congregation of Notre Dame Nineteenth Century Kingston," CCHA, Study Sessions 40 (1973): 27-33; Elizabeth Smyth, "Leading Congregations: Transforming Society, Catherine McKinley, Sister of Providence of St Vincent de Paul," History of Education Researcher 80 (2007): 122-35; "A Tale of Two
} 
Church are useful for timelines and basic data. ${ }^{37}$ However, there have been no comparative studies of the three congregations as they carried out social work in the City of Kingston from the 1840s to the 1870s. To do so is the purpose of this thesis.

This study of Kingston's Roman Catholic sisters' rests on extensive use of primary source material. In an historical era where women often did not leave abundant written records about their lives, sisters wrote detailed accounts of both their work and the challenges they faced in reports to General Superiors, personal correspondence, directives, financial accounts, and annals. The sisters' private letters, annals, and obituaries in the Archives of the Religious Hospitallers of Saint Joseph and Sisters of Providence of St. Vincent de Paul were a particularly rich source of information as they revealed much about individual sisters and their understanding of, and commitment to, the demands of religious life. Many of these documents provided a clearer picture of the sisters' lives, and their relationships with one another and the Kingston community. The Archives of the Congrégation de Notre-Dame provided fewer written accounts due to a fire several years ago that destroyed most of the records relating to their Kingston mission. The Kingston newspaper, The British Whig, was useful in gaining a contemporary sense of where the Catholic Church fit into the wider community. Government records proved invaluable, particularly the Journals of the Legislative Assembly, and Egerton Ryerson's correspondence and provincial reports about the state

Sister-Principals: Mother Mary Edward (Catherine) McKinley, Sisters of Providence of St. Vincent de Paul (Kingston, ON) and Mother Mary of Providence (Catherine) Horan, Sisters of Providence of Holyoke, MA," Encounters in Theory and History of Education 14 (2013): 119-32.

${ }^{37}$ Louis J. Flynn, Built On A Rock: The Story of the Roman Catholic Church in Kingston 1826-1976 (Kingston: Roman Catholic Archdiocese of Kingston, 1976). 
of education in the Province of Ontario. Anti-Catholic literature provided a fascinating window into the religious and social upheavals of the nineteenth-century.

This study of women's work allows us to appreciate as never before the opportunities afforded Canadian women who opted for the religious life. Although sisters could not escape prevailing ideas about femininity and the importance of women's restricted public roles, religious life offered women possibilities to move beyond their separate sphere that were uncommon for the time. Even before nursing became a profession, for example, nuns and sisters established and operated hospitals where they maintained high standards of care and enjoyed a reputation for cleanliness. Sisters offered girls and young women an education that qualified them for post-secondary study and professions, as they both became available. In the course of carrying out their nursing, charitable, and educational missions, sisters gained considerable administrative authority over their finances, homes, and the institutions they created, built, and nurtured over the years. These institutions delivered many of the services that would be provided by the state a century later. 


\section{Chapter 1: Whose Vision Would Prevail?: Faith and State Intertwined}

In his effort to persuade the Montréal Congrégation de Notre-Dame to open a mission in Kingston, Bishop Gaulin emphasized that its schools could be used to promote the Catholic Church to non-Catholics in positions of power: "Kingston, according to all appearances, being in the way of becoming the capital of Canada, it is exceedingly urgent that the Catholic religion may, by the appearance and the number of her institutions of education and of charity, make an impression, an effective impression, on those who judge mainly by the exterior." ${ }^{38}$ The year was 1841 and Bishop Bourget of Montréal and Bishop Gaulin of Kingston both foresaw the intensive government involvement and financial investment that would result from the unification of the Canadas. ${ }^{39}$ They anticipated that women religious would be enmeshed in Canada West's rapid development, including its changing policies, regulations, and laws, and hoped that their presence in the capital would prove advantageous to the Church. ${ }^{40}$ This chapter will explore how the interests of the Provincial Government and the overarching vision of Kingston's bishops intersected with the congregational aims of the Congrégation de Notre-Dame, Religious Hospitallers of St. Joseph, and the Kingston's Sisters of Providence, including the sisters' ambitions for those they served.

Because the English Poor Law was never enacted in Upper Canada, known as Canada West as of 1841, the earliest social services were provided by private religious

\footnotetext{
${ }^{38}$ ACNDM, 310.150.4, "Memorial of the Golden Jubilee, Convent C.N.D., Kingston, Province, Ont., 1841 1891."

39 "The Hon. Francis Hincks, Prime Minister of Canada," The Illustrated Magazine of Art 3, no. 17 (1854): 351-52.

40 J.M. Bumstead, "The Consolidation of British North America, 1783-1860," in Canada and the British Empire, ed. Philip Buckner (Oxford; New York: Oxford University Press, 2008), 61. See also J.M.

Bumstead, The Peoples of Canada: A Pre-Confederation History (Oxford; New York: Oxford University Press, 2010, $3^{\text {rd }}$ edition), 364-87.
} 
and charitable organizations. ${ }^{41}$ Despite Upper Canada's House of Industry Act, which

passed on March 4, 1837, ${ }^{42}$ very few of these Dickensian workhouses were built in

Canada West. By 1872, only four workhouses had been established in the Province of

Ontario, including in Kingston, that received provincial funding. ${ }^{43}$ Houses of Industry

were not popular with 'inmates,' many of whom reported the preference of spending a

season in jail to the poorhouse. ${ }^{44}$ Even with the state's sporadic, albeit increasing

involvement in aiding the "deserving poor," the majority of poor relief still fell to private

charities and churches up until the late nineteenth-century. ${ }^{45}$ Indeed, prior to

\footnotetext{
${ }^{41}$ Mariana Valverde, "The Mixed Social Economy as a Canadian Tradition," Studies in Political Economy 47 (Summer 1995): 38-39; Russell Smandych, "Colonial Welfare Laws and Practices: Coping without an English Poor Law in Upper Canada, 1792-1837," Manitoba Law Journal 23 (1995): 214-46; Rainer Baehre, "Pauper Immigration to Upper Canada in the 1830s," Social History 14, no. 28 (November 1981): 340; "Paupers and Poor Relief in Upper Canada," Historical Papers 16, no. 1 (1981): 57-80. See also Alvin Finkel, Social Policy and Practice in Canada: A History (Waterloo, Ont.: Wilfrid Laurier University Press, 2006), 39-64. Charlotte Neff has noted that although the English Poor Law was never enacted in Upper Canada, there was a legislated system of "pauper apprenticeship" for orphaned children as of 1799 . See Charlotte Neff, "Pauper Apprenticeship in Early Nineteenth Century Ontario," Journal of Family History 21, no. 2 (April 1996): 144, 148. See also "An Act to provide for the Education and Support of Orphan Children," Upper Canada, Statutes, 1799, 39 Geo. 3, c. 3, cited in Ibid., supra 2, 161.

42 "Act to authorize the Erection, and provide for the Maintenance of Houses of Industry, in the several Districts of this Province," Statues of His Majesty's Province of Upper Canada, Passed in the First Session of the Thirteenth Provincial Parliament of Upper Canada (Toronto: G. Tiffany, 1837), Chap. XXIV, 8081; Carol Wilton, Popular Politics and Political Culture: 1800-1850 (Montreal: McGill-Queen's University Press, 2000), 168-193; Anne O'Connell, "The Deserving and Non-deserving Races: Colonial Intersections of Social Welfare History in Ontario," Intersectionalities: A Global Journal of Social Work Analysis, Research, Polity, and Practice 2 (2013): 2, 11-12; Prashan Ranasinghe, "Vagrancy as a Penal Problem": The Logistics of Administering Punishment in Late-Nineteenth-Century Canada," Journal of Historical Sociology 10, no. 4 (December 1997): 537-38.

${ }^{43}$ Ontario, Sessional Papers, 1872, Vol. VI, no. 2, 133, cited in Splane, Social Welfare in Ontario, 82.

${ }^{44}$ Stormie Stewart, "The Elderly Poor in Rural Ontario: Inmates of the Wellington County House of Industry, 1877-1907," Journal of the Canadian Historical Association 3, no. 1 (1992): 217, 231.

${ }^{45}$ Michael J. Dear and Jennifer R. Wolch, Landscapes of Despair: From Deinstitutionalization to Homelessness (Princeton: Princeton University Press, 1987), 78-9; Edgar-André Montigny, Foisted Upon the Government?: State Responsibilities, Family Obligations, and the Care of the Dependent Aged in Late Nineteenth-Century Ontario (Montreal, Que.: McGill-Queen's University Press, 1997), 89-91; O'Connell, "The Deserving and Non-deserving Races," 2, 11-12; Paula Maurutto, Governing Charities: Church and State in Toronto's Catholic Archdiocese, 1850s-1950s (Montreal; Ithaca: McGill-Queen's University Press, 2003), 6-13; The Charity Aid Act was passed in 1874, but charities still relied on a mix of private and provincial funding. See Splane, Social Welfare in Ontario, 83.
} 
Confederation, a mere $9 \%$ of Ontario's colonial budget was spent on “charities, welfare, and education." 46

Prejudice towards people living in poverty was prevalent during the Victorian era. Many thought poverty indicative of a person's character, and that "the poor brought misfortunes upon themselves as a result of sloth, dissipation, or other moral lapses."47 This absence of state involvement placed the Catholic Church in a strong position to petition the provincial government for financial assistance, particularly when the Church's services were urgently required during public healthcare crises. ${ }^{48}$ The typhus epidemic was Kingston's most dramatic healthcare crisis, and it became a time when the government intervened to provide short-term financial assistance to Catholic nuns coping with an influx of orphaned children. ${ }^{49}$

\section{From Montréal to Kingston}

Between 1841 and 1861, Kingston's respective bishops, Rémi Gaulin, Patrick

Phelan, and John Edward Horan, recruited sisters and nuns from Montréal. They wanted women religious to establish schools, care for the sick, and serve the poor, especially the destitute, widowed, orphaned, elderly, homeless, and incarcerated women at Kingston Penitentiary (KP). Because many of Montréal's professed sisters were fluently bilingual,

\footnotetext{
${ }^{46}$ Finkel, Social Policy and Practice, 9, cited in Canada's Residential Schools: The History, Part 1: Origins to 1939: The Final Report of the Truth and Reconciliation Commission of Canada, Vol. 1 (Montreal \& Kingston: McGill-Queen's University Press, 2015), 66.

${ }^{47}$ Patricia E. Malcolmson, "The Poor in Kingston, 1815-1850," in To Preserve \& Defend, 294.

${ }^{48}$ Heather MacDougall, "“Truly Alarming': Cholera in 1832," Canadian Journal of Public Health 100, no. 5 (September/October 2009): 333-34; David Butler-Jones, "A Reflection on Public Health in Canada: Applying Lessons Learned for the Next Century of Public Health Practitioners," Canadian Journal of Public Health 100, no. 3 (May/June 2009): 165-66; Kathy Hardill, "From the Grey Nuns to the Streets: A Critical History of Outreach Nursing in Canada," Public Health Nursing 24, no.1 (January-February 2007): 91-97.

${ }^{49}$ Patrick Donovan, "Irish Famine Orphans in Canada," in The Canadian Encyclopedia (Toronto: Historica Canada, 1985-. Article published September 19, 2016, http://www.thecanadianencyclopedia.ca/en/article/irish-famine-orphans-in-canada/.
} 
they could be of great benefit to Kingston's Anglophone and Francophone communities. But although Catholic bishops held ultimate power in matters of morals and doctrine, they could not force religious congregations to move from one diocese to another. Bishops had to negotiate with nuns and sisters in ways other men in Canada's Victorian era rarely did with the women in their lives. ${ }^{50}$ When Bishop Horan first contacted Reverend Mother Philomène, the Mother Superior of Montréal's Sisters of Providence, requesting that she send three or four of her sisters to Kingston, for example, she refused. ${ }^{51}$ There were no sisters who wanted to start a new mission there, and besides, there were no sisters to spare. ${ }^{52}$ Church protocol required religious congregations to be invited into a diocese and for the transfer of religious personnel to be mutually agreed upon by all parties. Diocesan priests had to be "incardinated" when permanently appointed to a new diocese. ${ }^{53}$ That is, they had to be officially placed under the jurisdiction of the diocesan bishop to which they were transferred. Religious communities of men and women required the same permission from their respective bishops to transfer and attach themselves to a new diocese and jurisdiction of its bishop. ${ }^{54}$ Given that their vows ensured nuns and sisters were dedicated and obedient, and that the structure of their

\footnotetext{
${ }^{50}$ See Nancy Christie, “'Proper Government and Discipline’: Family, Religion, and Masculine Authority in Nineteenth-Century Canada," in What is Masculinity?: Historical Dynamics from Antiquity to the Contemporary World, ed. John H. Arnold and Sean Brady (New York: Palgrave Macmillan, 2011), 389412.

${ }^{51}$ Sister Mary Electa, The Sisters of Providence of St. Vincent de Paul (Montreal: Palm Publishers, 1961), 35.

${ }^{52}$ Ibid., 35.

${ }^{53}$ For a full definition of incardination, see Michael Walsh, The Cardinals: Thirteen Centuries of the Men Behind the Papal Throne (Grand Rapids, Michigan; Cambridge, United Kingdom: William B. Eerdmans Publishing Company, 2010), 2.

${ }^{54}$ For different examples and case studies about incardination and transferring dioceses, see Rose McDermott, The Consecrated Life: Cases, Commentary, Documents, Readings (Alexandria, VA: Canon Law Society of America, 2006).
} 
religious communities meant they were self-governed and usually financially independent, sisters and nuns were considered a valuable resource for any diocese. ${ }^{55}$

Each religious community had a distinctive "charism" that underpinned how they lived out their vocations. Sisters considered their charism a "gift of the holy spirit" that determined their "identity, way of life, spirit and spirituality, structures, and mission." 56 The Rule, also known as the Constitutions, was specific to their charism and defined the roles and duties of each sister, their spirituality and their vows; it also outlined what was expected of them as religious. ${ }^{57}$ Constitutions laid out a congregation's "mission" or its goals, and how the congregation was to manage itself. Essentially, each community's rule was the blueprint for how to live as a religious in that congregation. The Customary provided rules regarding the women's daily schedule and how they were to live, including their dress. ${ }^{58}$ The Ceremonial described the vows and the ceremony involved in praying and attending Mass, that is, when and where they were to sit, stand, kneel, and bow. The charism of these congregations was established by the original vision and work of the founders. Constitutions, however, were often written in consultation with ecclesiastical authorities and were only truly valid after having received the bishop's approval and papal approbation. The founding spirit of a congregation can be discovered in its constitutions.

\footnotetext{
${ }^{55}$ For example, see Kathryn Burns, Colonial Habits: Convents and the Spiritual Economy of Cuzco, Peru (Durham, NC: Duke University Press, 1999), 86-90.

${ }^{56}$ S.M. Sanders, "Charisms, Congregational Sponsors, and Catholic Higher Education," Journal of Catholic Higher Education 29, no. 1 (2010): 4.

${ }^{57}$ For example, see the Archives of the Religious Hospitallers of St. Joseph, Rules and Constitutions for the Religious Hospitalers of St. Joseph (Kingston: William Bailie, Printer, King Street, 1872).

${ }^{58}$ For example, see The Customary and Little Rules of the Religious Hospitallers of the Congregation of St. Joseph (E. Jourdain, La Flèche: 1850; English trans., Hôtel-Dieu, Kingston: 1901).
} 
A congregation's charism, and therefore its constitutions, were dependent on the vision of its founder(s). These three religious institutes can properly be said to have multiple founders; however, only the key women will be discussed here. The three main 'foundresses' of each congregation examined in this study were women of the seventeenth and early nineteenth centuries. They were embedded in times and places when women had few opportunities and their interactions with men were circumscribed by societal norms, ecclesiastical authorities, and their Rule. Examining the original ideals of the Congrégation de Notre-Dame, Religious Hospitallers of St. Joseph, and the Sisters of Providence provides the necessary context to understand each group's charism, their intertwined histories, and why women were drawn to these communities.

French Catholic lay women were freed by France's sixteenth-century CounterReformation, which continued into the seventeenth-century, to undertake an active part in religious ministry. Susan E. Dinan and Debra Meyers have examined the Protestant and Catholic spiritual revivals that swept Early Modern Europe through a gendered lens, arguing that the upheaval created new spaces for women. It was a period when the Roman Catholic Church "re-created itself with a clearly articulated theology and a new, educated and disciplined corps of male and female reformers." ${ }^{, 59}$ In his 1609 publication, Introduction à la vie dévote, Francis de Sales popularized the idea that all members of the Catholic Church, not only those with vocations to religious life, could live out lives of religious perfection. ${ }^{60} \mathrm{He}$ wrote, "It is an error, nay a heresy to wish to banish the devout life from the army, from the workshop, from the courts of princes, from the households of

\footnotetext{
${ }^{59}$ Susan E. Dinan and Debra Meyers, eds., "Introduction," in Women and Religion in Old Worlds and New (New York; London: Routledge, 2001), 1.

${ }^{60}$ See Patricia Byrne, review of The Dévotes: Women and Church in Seventeenth-Century France, by

Elizabeth Rapley, Social History 27, no. 54 (1994): 476.
} 
married folk. ... Wherever we are, we may and ought to aspire to the perfect life."61

Elizabeth Rapley has described how from such teachings sprang lay women known as filles séculières or filles dévotes: unmarried women who did not take religious vows, lived communally 'in the world', and were part of their local parish. ${ }^{62}$ All three congregations and their main founders discussed here had their roots in the filles dévotes movement, and later dedicated themselves to working with or forming new religious institutes as a route to expanding their religious works. ${ }^{63}$

The Religious Hospitallers of St. Joseph were founded by Jérôme Le Royer de La Dauversière and Marie de la Ferre in 1636 in La Flèche, France. ${ }^{64}$ It was Jérôme Le Royer and his fellow members of the Société Notre-Dame de Montréal who sponsored Jeanne Mance, a dévote from Langres, France, to establish the Hôtel-Dieu Hospital in New France in $1642 .{ }^{65}$ Mance is also credited as the cofounder of Ville-Marie, now City of Montréal, with Paul de Chomedey de Maisonneuve, her swift action having saved the colony from destruction. ${ }^{66}$ She later returned to France and recruited French colonists and soldiers when the early settlers of Montréal were at their lowest ebb. ${ }^{67}$ In 1659 , the

\footnotetext{
${ }^{61}$ Francis de Sales, Introduction to the Devout Life, trans. and ed. Allan Ross (Mineola, New York: Dover Publications, 2009), 42.

${ }^{62}$ Elizabeth Rapley, The Dévotes: Women and Church in Seventeenth-Century France (Kingston, Ont.: McGill-Queen's University Press, 1990), 17-18, 93-95, 100-11, 113.

${ }^{63}$ Robert Bireley, The Refashioning of Catholicism, 1475 to 1700: A Reassessment of the Counter Reformation (Washington, D.C.: Catholic University of America Press, 1999), 37.

64

${ }^{65}$ Dom Guy-Marie Oury, OSB, Jeanne Mance and the Dream of Mr. De La Dauversière, trans. Sr. Sheila Boase, RHSJ (Kingston: Religious Hospitallers of St. Joseph, n.d.), 57-68; Marie-Claire Daveluy, "MANCE, JEANNE," in Dictionary of Canadian Biography, vol. 1, University of Toronto/Université Laval, 2003-, accessed March 21, 2018, http://www.biographi.ca/en/bio/mance_jeanne_1E.html. See also Francoise Deroy-Pineau, Jeanne Mance: From Langres to Montreal, the Passion for Caring, trans. Sr. Sheila Boase, RHSJ (Kingston: Religious Hospitallers of St. Joseph, n.d).

${ }^{66}$ Jan Noël, Women in New France (Ottawa: Canadian Historical Association, Historical Booklet 59, 1998), 4-5. Both Paul de Chomedey de Maisonneuve and Jeanne Mance had been sponsored by the Société Notre-Dame de Montréal to found Ville-Marie, the early colony of Montréal.

${ }^{67}$ Janet Noël, "Sisters in Arms: Quebec Convents at the Crossroads of Empire," in A Companion to Women's Military History, ed. Barton C. Hacker and Margaret Vining (Brill Publishing: Leiden; Boston,
} 
Religious Hospitallers joined Mance, who despite her devotion never became a sister herself, to work in the Hôtel-Dieu Hospital. ${ }^{68}$ In their description of their charism, the erection of the Hôtel-Dieu was in response to "so many of the poor abandoned in extreme indigence, particularly in their sickness, during which they are frequently left alone without the sacraments, without consolation, deprived of every convenience and assistance." ${ }^{69}$ Their constitutions further state:

This is what induced several holy persons, inspired by God, to unite and erect this congregation, that the persons composing it, being conjointly united by God, and guided by the same spirit, might labour more advantageously for the glory of God, the relief of the sick poor, and they might exercise in their behalf all the works of mercy, both spiritual and corporal, without any other interest than that of the pure love of God, and of perfect charity for their neighbour. ${ }^{70}$

A contemporary of Jeanne Mance, Marguerite Bourgeoys, founded the Congrégation de Notre-Dame of Montréal in seventeenth-century New France with a group of dedicated French dévotes. ${ }^{71}$ Bourgeoys arrived from Troyes, France in 1653, and with her female companions established free schools for French and Indigenous girls throughout New France. ${ }^{72}$ Jeanne Mance and Margeurite Bourgeois, "embodied the rhetoric of colonization," 73 and were integral to France's political agenda and the

\footnotetext{
2012) 409-430. For a contemporary perspective, see François Dollier de Casson, Histoire du Montréal, 1640-1672 (Montréal: 1871, reprint).

${ }^{68}$ Oury, Jeanne Mance, 27, 75, 199-222. For a contemporary history of the arrival of the Religious Hospitallers in 1659, see [Sister] Marie Morin, The Annales of Hotel Dieu of Montreal, 1659-1725: Simple and True History of the Establishment of the Religious Hospitallers of Saint Joseph on the Island of Montreal Called at Present Ville Marie in Canada from the Year 1659, trans. Sr. Sheila Boase, RHSJ, from the critical edition of Ghislaine Legendre (Montréal: Les Éditions Carte blanche, 2010).

${ }^{69}$ Religious Hospitallers of St. Joseph, Rules and Constitutions for the Religious Hospitalers of St. Joseph, 29.

${ }^{70}$ Ibid.

${ }^{71}$ Gray, The Congrégation de Notre-Dame, 9 Patricia Simpson, Marguerite Bourgeoys and the Congregation of Notre-Dame, 1665-1700 (Montreal; Ithaca: McGill-Queen's University Press, 2005), 4, 9.

${ }^{72}$ Jan Noël, Women in New France, 4-5.

${ }^{73}$ Thomas Carr, "Writing the Convent in New France: The Colonialist Rhetoric of Canadian Nuns," Quebec Studies 47 (Spring/Summer 2009): 3.
} 
Church's conversion project. ${ }^{74}$ The sisters, initially an uncloistered community of lay women, received canonical status as the Congrégation de Notre-Dame in $1671 .{ }^{75}$ Under the 'Article Premier' of their original constitutions, the Congrégation de Notre-Dame explained their charism in this way: "I. Chaque chose tire sa plus grande perfection de la bonté de sa fin."76 Despite ecclesiastical intervention, the Congrégation de Notre-Dame maintained their original vision as a group of apostolic women religious, and have remained active in their parishes and local communities since the seventeenth-century. ${ }^{77}$

The Sisters of Providence of St. Vincent de Paul, as they are presently known, were founded in Kingston in 1861. Their ecclesiastical founder was Bishop Edward Horan and Sr. Mary Edward, the first superior appointed by Bishop Horan in 1866, is considered their foundress. ${ }^{78}$ However, their roots were in Montréal as the Daughters of Charity, Servants of the Poor. Émilie Tavernier Gamelin was the first superior of the Montréal sisters. She attended the Congrégation de Notre-Dame's school as a boarding student in Montréal and married in 1823. In 1827, Émilie Gamelin was widowed at the young age of 27. Following the tragic death of her three children, her third child dying only months after her husband passed away, Madame Gamelin devoted herself to

\footnotetext{
74 Janet Noël, Along a River: The First French-Canadian Women (Toronto: University of Toronto Press, 2012), 55 .

${ }^{75}$ Allan Greer, The People of New France (Toronto; Buffalo: University of Toronto Press, 1997), 71-73; Mary Anne Foley, "La vie voyagère for Women: Moving beyond Cloister in Seventeenth-Century New France," CCHA, Historical Studies, 63 (1997): 15-28; Elizabeth Rapley, The Dévotes, 95, 100-11, 113; Gray, The Congrégation de Notre-Dame, 8-9, 18-19; Marta Danylewycz, Taking the Veil, 18-19. See also Simpson, Marguerite Bourgeoys and the Congregation of Notre-Dame, 3-10; Marguerite Bourgeoys and Montreal, 1640-1665 (Montréal: McGill-Queen's University Press, 1997).

${ }^{76}$ ACNDM, 700.010-001, Règlements de la Congrégation de Notre-Dame (Bureau des Mélanges Religieux: Montréal, 1846), 48.

${ }^{77}$ Mary Anne Foley, “'We Want No Prison Among Us': The Struggle for Ecclesiastical Recognition in Seventeenth-Century New France," U.S. Catholic Historian 14, no. 1, Beyond the Walls: Women Religious in American Life (Winter 1996): 1-18.

${ }^{78}$ ASPSVP, 410.3.22, Particular Law Collection, Customs and Spiritual Heritage, Spiritual Heritage, 15.
} 
charitable works. ${ }^{79}$ Gamelin created a secular community of women caring for the needs of single, elderly women in distress, similar to the seventeenth-century filles séculières. ${ }^{80}$ Gamelin first housed these women in her own home, then in rented quarters, and finally in a larger donated property. Through donors and the women who joined her to care for the elderly, Émilie Gamelin's charitable works expanded to include other sick and needy individuals. In September of 1841, her home for elderly women was incorporated by the Legislative Assembly of the Province of Canada. From its simple beginnings, her place of shelter became the Montréal Asylum for Aged and Infirm Women. Émilie Gamelin's active support of the Patriotes does not appear to have interfered with her positive relationship with the British state. In 1832, Gamelin was one of 226 women who voted for a Patriote candidate. She was permitted to visit jailed Patriotes during the Rebellions of 1837-1838 and bring letters home to their loved ones. Her obvious commitment to care for those on both sides of the conflict, regardless of creed, denomination, or political beliefs, must have been evident to the British authorities. Madame Gamelin's visits to the incarcerated political rebels may have been the instigation of an aspect of the sisters' charism to care for the imprisoned. ${ }^{81}$

Bishop Ignace Bourget persuaded Émilie Tavernier Gamelin to join the new congregation he wanted to establish. It would be modeled on France's Filles de la Charité

\footnotetext{
${ }^{79}$ Émilie Gamelin's first two babies died in infancy. See André-M. Cimichella, Émilie Tavernier Gamelin: The Great Lady of Montréal, Foundress of the Sisters of Providence (Outremont, Québec: Les Éditions Carte Blanche, 2002), 14-15.

${ }^{80}$ Bettina Bradbury, Wife to Widow: Lives, Laws, and Politics in Nineteenth-Century Montreal (Vancouver: UBC Press, 2011), 292-301.

${ }^{81}$ Marguerite Jean, "TAVERNIER, ÉMILIE," in Dictionary of Canadian Biography, vol. 8, University of Toronto/Université Laval, 2003-, accessed August 9,

2018, http://www.biographi.ca/en/bio/tavernier_emilie_8E.html. See also Henri Giroux, Une hérö̈ne du Canada: Madame Gamelin et ses oeuvres, (Montréal, s.n., 1885); Gustave Bourassa, Madame Gamelin et les origines de Providence: lecture faite à la clôture du bazar annuel de l'Asile de la Providence (Montréal: s.n., 1892).
} 
de Saint-Vincent-de-Paul and organized in a manner similar to Elizabeth Seton's Sisters of Charity in the United States. ${ }^{82}$ The Daughters of Charity, Servants of the Poor also followed the Rule of St. Vincent de Paul and officially received canonical status through Bishop Bourget's presentation of their constitutions to Pope Gregory XVI in 1844.

The Filles de la Charité were one of the original seventeenth-century groups of filles séculières and retained much of the early spirit of St. Vincent de Paul, a contemporary of St. Francis de Sales and an early champion of sisters' active community involvement outside the cloister. ${ }^{83}$

Bishop Horan sought out the Sisters of Providence from Montréal to teach, care for, and serve Kingston's neediest, but as will be discussed in Chapter 3, he also exerted his personal control over the sisters and Catholic lay people. The original charism of Kingston's Daughters of Sisters of Charity is summarized at the very beginning of the Montréal Daughters of Charity’s Rule, given in 1881 to Sister Mary John, General Superior of Kingston, and translated for the sisters' use: " $1^{\text {st }}$ The principal end for which God called together the Daughters of Charity is to honor our Lord Jesus Christ as the source and model of all charity, serving Him corporally and spiritually in the person of the poor, whether they are the sick children, prisoners, or others who through shame, dare

\footnotetext{
${ }^{82}$ Electa, The Sisters of Providence of St. Vincent de Paul, 17-18. See also Hazel Mills, “'La Charite est une Mère': Catholic Women and Poor Relief in France, 1690-1850," in Charity, Philanthropy, and Reform: From the 1690s to 1850, ed. Hugh Cunningham and Joanna Innes (New York: St. Martin's Press, 1998), 168-192.

${ }^{83}$ For the best discussion of Émilie Tavernier Gamelin, and specifically her political actions, see Jean, “TAVERNIER, ÉMILIE," http://www.biographi.ca/en/bio/tavernier_emilie_8E.html; Elizabeth Rapley, The Dévotes, 95, 113. See also Bettina Bradbury, « Mourir chrétiennement : La vie et la mort dans les établissements catholiques pour personnes âgées à Montréal au XIXe siècle ", Revue d'histoire de l'Amérique française 46, no. 1 (1992): 143-175, doi:10.7202/305051ar. For a study of Vincent de Paul's influence, see Patricia Wittberg, From Piety to Professionalism - and Back?: Transformations of Organized Religious Virtuosity (Lanham, MD: Lexington Books, 2006 ), 6; Hugh F. O’Donnell, C.M., "Vincent de Paul: His Life and Way," in Vincent de Paul and Louise de Marillac: Rules, Conferences, and Writings, ed. John E. Rybolt and Frances Ryan (New York, N.Y.; Mahwah, N.J.: Paulist Press, 1995), 1338.
} 
not make their wants known." ${ }^{84}$ Their mission, as they saw it, was to subvert the idea that limited respectability to wealth or status.

\section{Sisters as Women: Social Networks and Healthcare}

In her study of Women and Philanthropy in Nineteenth-Century Ireland, historian Maria Luddy has discussed how nuns had access to public institutions in ways secular women did not because of their "otherworldly commitment." ${ }^{85}$ However, nineteenthcentury social mores and ideas about "feminine delicacy" followed women into the convent. ${ }^{86}$ Transformed through their vows, sisters became spiritual mothers to the needy, and directed their philanthropic efforts towards women and children rather than men. Luddy points out that it would not have been socially acceptable in the nineteenthcentury, or in keeping with the sisters' constitutions, to assist men in the way male congregations were permitted. ${ }^{87}$ Sisters were able to serve men through medical services, even if propriety demanded certain restrictions.

\section{Women as Nurturers: Hôtel-Dieu Hospital}

In September of 1845, the Hôtel-Dieu nuns arrived in Kingston to establish a hospital and began caring for the sick immediately. Unlike the Congrégation de NotreDame and the Sisters of Providence, the Religious Hospitallers of Saint Joseph were cloistered. Sociologist Patricia Wittberg has noted that even in the nineteenth-century, "there was a strong tendency within both the Church hierarchy and the orders themselves

\footnotetext{
${ }^{84}$ ASPVP, Daughters of Charity, Servants of the Poor of Montréal, "Rule of the Daughters of Charity," translated into English, 1881, 1.

${ }^{85}$ Luddy, Women and Philanthropy, 51.

${ }^{86}$ Darren Ferry, Uniting in Measures of Common Good: The Construction of Liberal Identities in Central Canada, 1830-1900 (Montreal; Ithaca: McGill-Queen's University Press, 2008), 224.

${ }^{87}$ Ibid.
} 
to see the purely contemplative life as superior-and the active service as the inferiorspiritual path." 88 The Religious Hospitallers were a combination of contemplative and active, and as such, they were the bridge between the private and the public spheres that women inhabited.

The Hôtel-Dieu nuns subscribed for another wing to be added to their hospital in 1846, and by 1847 their hospital was comfortably housing patients. ${ }^{89}$ The nuns were in control and had obtained the necessary financial backing. This contrasted with the Ladies of the Female Benevolent Society, well-heeled society ladies of varying Protestant Christian denominations, who had established Kingston's first charity hospital in 1820 with less immediate success. ${ }^{90}$ The Benevolent Society was an ecumenical group. In a period when denominations marked social circles and socio-economic class, it was uncommon to have members of the Wesleyan, Methodist, and Anglican churches raising funds and taking part in social events together. ${ }^{91}$ However, it was to the whole community’s benefit. Kingston’s Female Benevolent Society had been granted $£ 3000$ from the Provincial Government in 1832 and other assistance through the years, but various troubles, including a fire, a lack of money, personnel and space, meant that the Kingston General Hospital did not officially open its doors until November of 1845, in the former building of the Provincial Parliament. ${ }^{92}$ Rather than viewing the two establishments as competitors, the women worked together to serve the Kingston public.

\footnotetext{
${ }^{88}$ Patricia Wittberg, From Piety to Professionalism - and Back?, 6.

${ }^{89}$ Rodney G.S. Carter, “'Agreeably surprised and more than pleased': The Religious Hospitallers of St. Joseph, the Hotel Dieu Hospital, and Regiopolis College," Historic Kingston 58 (2010): 26-7.

${ }^{90}$ Margaret Angus, Kingston General Hospital (Kingston; Montréal: McGill-Queen's University Press, 1973), 4.

${ }^{91}$ Cecelia Morgan, Public Men and Virtuous Women: The Gendered Languages of Religion and Politics in Upper Canada, 1791-1850 (Toronto: University of Toronto Press, 1996): 202-07.

92 Ibid., 4-7, 11-13, 19, 189-190.
} 
This will be discussed in Chapter 2. Importantly, Kingston's Ladies of the Female Benevolent Society and the nuns lived out the fine line between the public and private spheres, which the nuns negotiated on a regular basis, and were part of each other's wider social network.

When women made their final profession as sisters or nuns, they severed close ties with parents, siblings, in-laws, nieces, nephews, friends, and even adult children. Sisters exchanged the tightknit relationships they may have had 'in the world' for a ready-made religious family in the convent, some of whom were also biological relatives or friends. Kingston's Notre-Dame annalist listed former Kingston students and the religious congregations they entered, which shows how deeply interwoven the social web of religious life was for these women. ${ }^{93}$ Upon making final profession sisters gained a transnational network of fellow men and women religious equally committed to the Catholic Church and its many causes. ${ }^{94}$ Sisters also gained basic economic security, a secure and respectable place in society, and opportunities for work. For single or widowed women, life outside marriage and the family unit was often uncertain and full of financial hardship. Sisters and nuns earned their own income and determined the prosaic details of life for their patients and students, such as accommodation, diet, and curriculum. They also provided and received emotional fulfilment from those in their care. The sisters and nuns who moved to Kingston initially received partial financial

\footnotetext{
${ }^{93}$ ACNDM, 310.150.4, "Memorial of the Golden Jubilee, Convent C.N.D., Kingston, Province, Ont., 18411891."

${ }^{94}$ For an overview of transnationalism, see Steven Vertovec, Transnationalism (London; New York: Routledge, 2009).
} 
support from the diocese for their housing, and occasional funding from the provincial

government for their work, but were ultimately self-reliant. ${ }^{95}$

\section{Kingston: A Sense of Place}

Situated on traditional Anishinaabe and Haudenosaunee territory, located where

the Great Cataraqui River, the St. Lawrence River, and the eastern end of Lake Ontario

meet, the future City of Kingston was a fiercely contested site between Indigenous and

European powers throughout the seventeenth and eighteenth centuries. ${ }^{96}$ Fort Cataraqui,

also known as Fort Frontenac, was originally established by Governor Frontenac of New

France in 1673 as a defensive stockade and trading post to exploit the lucrative fur

trade. ${ }^{97}$ By the turn of the eighteenth-century, the Mississauga-Anishinaabeg had gained

\footnotetext{
${ }^{95}$ For instance, in 1862 , prior to their incorporation, the provincial government gave $£ 1000$ to the HôtelDieu Hospital to enable them to carry out their services. Funding was also provided to the Orphan Asylum. A total amount of $£ 800$ was provided to the Orphan Asylum. Although the provincial accounts do not specify which orphanage received the funds, it is likely the money was intended for the Protestant Orphan Asylum. The Kingston General Hospital received $£ 6000$, and Kingston’s Indigent Sick received $£ 3000$. For these financial accounts, see Sessional Papers, 25 Victoria, A 1862, no. 4, Journals of the Legislative Assembly of the Province of Canada, Volume 20, First Session of the Seventeenth Parliament, Session 1862.

${ }^{96}$ Brian S. Osborne and Donald Swainson, Kingston: Building on the Past for the Future (Kingston: Quarry Heritage Books, 2011), 18-46; Nick Adams, "Iroquois Settlement at Fort Frontenac in the Seventeenth and Early Eighteenth Centuries" Ontario Archaeology no. 46 (1986): 5-20. See also Daniel K. Richter, The Ordeal of the Longhouse: The Peoples of the Iroquois League in the Era of European Colonization (Chapel Hill: University of North Carolina Press, 1992); Before the Revolution: America's Ancient Pasts (Cambridge, Mass.: Belknap Press of Harvard University Press, 2011); Bruce Elliott Johansen and Barbara Alice Mann, eds. Encyclopedia of the Haudenosaunee (Iroquois Confederacy) (Westport, Conn.: Greenwood Press, 2000); Edward J. Hedican, The First Nations of Ontario: Social and Historical Transitions (Toronto: Canadian Scholars, 2017); Cecilia Morgan, Travelers Through Empire: Indigenous Voyages from Early Canada (Montreal; Kingston: McGill-Queen's University Press, 2017). For a deeper understanding of the historical relationship between Indigenous peoples and settlers, as well as the issues surrounding contested Canadian territory, see Glen S. Coulthard, "Subjects of Empire: Indigenous Peoples and the 'Politics of Recognition' in Canada," Contemporary Political Theory 6, no. 4 (November 2007): 437-60; Adam J. Barker, "The Contemporary Reality of Canadian Imperialism, Settler Colonialism and the Hybrid Colonial State," The American Indian Quarterly 33, no. 3 (Summer 2009): 325-51; Zoë Laidlaw, ed., Indigenous Communities and Settler Colonialism: Land Holding, Loss and Survival in an Interconnected World (Houndmills, Basingstoke, Hampshire: Palgrave Macmillan, 2015); Greg Poelzer and Ken S. Coate, From Treaty Peoples to Treaty Nation: A Road Map for All Canadians (Vancouver; Toronto: UBC Press, 2015).

${ }^{97}$ Richter, The Ordeal of the Longhouse, 130-132; Osborne and Swainson, Kingston, 7-17; Ontario Dept. of Public Records and Archives, Historic Ontario (Toronto: Dept. of Tourism and Information, 1967), 52; John G. Bourinot, Canada under British Rule, 1760-1900 (Cambridge: University Press, 1900), 18.
} 
control of much of Southern Ontario through a peace treaty with the Haudenosaunee, and chose not to involve themselves in the lengthy European conflicts, known as the Territorial Wars, taking place on their land. ${ }^{98}$ The Haudenosaunee Confederacy (Iroquois) battled for the Fort during the Seven Years' War before it was eventually captured by their British allies in $1758 .{ }^{99}$ France formally ceded its colony to the British through the 'Peace of Paris' treaty, signed on February 10, 1763. ${ }^{100}$ In accordance with the Royal Proclamation of 1763, the British Crown acquired the Cataraqui region from the Mississauga in October of 1783 as part of the "Crawford Purchase."101 Within months the colonial government had settled "King's Town" with United Empire Loyalists. ${ }^{102}$ It was a deeply deceptive exchange. Captain W. R. Crawford, commanding officer at the Fort Frontenac garrison, brokered a deal on behalf of the

\footnotetext{
${ }^{98}$ Michael Ripmeester, “'It is scarcely to be believed...': The Mississauga Indians and the Grape Island Mission, 1826-1836," The Canadian Geographer 39, no. 2 (1995): 158; Heidi Bohaker, "Anishinaabe Toodaims: Contexts for Politics, Kinship, and Identity in the Eastern Great Lakes," in Gathering Places: Aboriginal and Fur Trade Histories, ed. Carolyn Podruchny and Laura Peers (Vancouver; Toronto: UBC Press, 2010), 100-104.

${ }^{99}$ Osborne and Swainson, Kingston, 7-17; Ontario Dept., Historic Ontario, 52; Colin G. Calloway, The Scratch of a Pen: 1763 and the Transformation of North America (Oxford, England; New York: Oxford University Press, 2006), 5. See also John E. Crowley, “'Taken on the Spot': The Visual Appropriation of New France for the Global British Landscape," The Canadian Historical Review 86, no. 1 (March 2005): $1-28$.

${ }^{100}$ Calloway, The Scratch of a Pen, 3. For a contemporary perspective from the period, see the anonymous Reflections on the Terms of Peace (London: Printed for G. Kearsly, 1763).

${ }^{101}$ Robert Bothwell, A Short History of Ontario (Edmonton: Hurtig Publishers Ltd., 1986), 20; Calloway, The Scratch of a Pen, 112-32; Edward S. Rogers and Donald B. Smith, eds., Aboriginal Ontario:

Historical Perspectives on the First Nations (Toronto: Dundurn Press, 1994), 101-3. For an in-depth discussion of the Royal Proclamation of 1763, see Terry Fenge and Jim Aldridge, eds., Keeping Promises: The Royal Proclamation of 1763, Aboriginal Rights, and Treaties in Canada (Montréal; Kingston: McGillQueen's University Press, 2015).

${ }^{102}$ Maya Jasanoff, "The Other Side of Revolution: Loyalists in the British Empire," The William and Mary Quarterly, Third Series, 65, no. 2 (April 2008): 213. See also Janice Potter-MacKinnon, While the Women Only Wept: Loyalist Refugee Women (Montreal, Que.: McGill-Queen's University Press, 1993), xiii-xvi; John G. Reid and Elizabeth Mancke, "From Global Processes to Continental Strategies: The Emergence of British North America to 1783" in Canada and the British Empire, ed. Philip Buckner (Oxford; New York: Oxford University Press, 2008), 22, 41; Elizabeth Jane Errington, "British Migration and British America, 1783-1867," in Canada and the British Empire, ed. Philip Buckner (Oxford; New York: Oxford University Press, 2008), 143.
} 
colonial government to trade European goods, such as blankets and guns, for thousands of acres of arable land on the north and east side of Lake Ontario. ${ }^{103}$ Frederick Halimand, Commander of the British forces, then ordered the Mississauga be "kept away from Kingston."104

The passage of Canada's Constitutional Act of 1791, English common law, and British migration transformed Upper Canada to the detriment of the Anishinaabe and Haudenosaunee's way of life and livelihood. ${ }^{105}$ The Brant family's experience appears to be a notable exception in a history marked by inequitable relations between Kingston's Indigenous peoples and its settlers. Koñwatsiãtsiaiéñni (Mary “Molly” Brant), sister of the brilliant and contentious Kanyen'kehá:ka (Mohawk) leader, Thayendenegea (Joseph Brant), spent her final years in Kingston, where on top of her annual pension of $£ 100$ for her services to the Empire, the colonial government built her a home, and one of her daughters married into the town's Anglo-elite. ${ }^{106}$ In contrast, the Mississauga were

\footnotetext{
${ }^{103}$ Ripmeester, “'It is scarcely to be believed...," 159; Alan Taylor, The Divided Ground: Indians, Settlers, and the Northern Borderland of the American Revolution (New York: Vintage Books, 2007), 13034; David T. McNab, Circles of Time: Aboriginal Land Rights and Resistance in Ontario, (Waterloo, Ontario: Wilfrid Laurier University Press, 1999), 51-54. According to Margaret Angus, there was a storehouse in Kingston to store presents for nearby Indigenous Peoples. Whether these were annual gifts as part of the Crawford Purchase, or other treaties, it is not clear. See Angus, Kingston General Hospital, 2. ${ }^{104}$ Ripmeester, “'It is scarcely to be believed...,"” 159.

${ }^{105}$ Valerie Knowles, Strangers at our Gates: Canadian Immigration and Immigration Policy, 1540-2015, $4^{\text {th }}$ ed. (Toronto: Dundurn, 2016), 48-67.

${ }^{106}$ Cecilia Morgan, Creating Colonial Pasts: History, Memory, and Commemoration in Southern Ontario, 1860-1980 (Toronto: University of Toronto Press, 2015), 45-48; Elizabeth Elbourne, "Family Politics and Mohawk Diplomacy: The Brant Family in Imperial Context," Journal of Colonialism and Colonial History 6, no. 3 (Winter 2005): n.page, 10.1353/cch.2006.0004; Barbara Graymont, "KOÑWATSI'TSIAIÉÑNI (Mary Brant)," in Dictionary of Canadian Biography, vol. 4, University of Toronto/Université Laval, 2003-, accessed May 5, 2018, http://www.biographi.ca/en/bio/konwatsitsiaienni_4E.html. See also Gretchen Green, "Molly Brant, Catherine Brant, and Their Daughters: A Study in Cultural Acculturation," Ontario History 81, no. 3 (1989): 235-50.
} 
treated with disdain, pushed to the margins of Kingston society, and resettled on reserve

land. $^{107}$

\section{Kingston: A City of Settlers}

By the mid-nineteenth-century, Kingston was an entirely changed place from the one the Mississauga once knew. In 1840, an estimated twelve thousand migrants journeyed through Kingston on their way west or towards the United States. ${ }^{108}$ This was a remarkable number given that the 1841 Census of Kingston census recorded the population to be $6,292 .^{109}$ By the beginning of the 1840 s, there were nearly five hundred thousand settlers and 8,000 Indigenous peoples in Upper Canada. ${ }^{110}$ In Kingston, it was predominantly Irish migrants, as well as English, Scottish, and Welsh, who joined the small settler community of French-speaking Canadiens. ${ }^{111}$ The earliest Scottish Roman Catholic and Protestant settlers had good relations. Their shared culture, and shared enemy, the English administration, drew them together in spite of their differences in

\footnotetext{
${ }^{107}$ Ripmeester, “'It is scarcely to be believed...," 159; Taylor, The Divided Ground, 130-34; McNab, Circles of Time, 51-54.

108 Julia Roberts, In Mixed Company: Taverns and Public Life in Upper Canada (Vancouver: UBC Press, 2009), 126.

${ }^{109}$ For Kingston's population statistics from 1841, see Table 6.3 "Principal Urban" in J.K. Johnson, In Duty Bound: Men, Women, and the State in Upper Canada, 1783-1841 (Montreal: McGill-Queen's University Press, 2014), 175.

${ }^{110}$ Rogers and Smith, Aboriginal Ontario, 112.

${ }^{111}$ Jason King, "Ireland and Canada," in Ireland and the Americas: Culture, Politics, and History: A Multidisciplinary Encyclopedia, Vol. 1, ed. Patrick Byrne, Philip Coleman, Jason King (Santa Barbara, California: ABC CLIO Inc., 2008), 6-7; Lucille H. Campey, An Unstoppable Force: The Scottish Exodus to Canada (Toronto: National Heritage Books, 2008), 43, 195, 201. For a further discussion of this pattern of migration from the British Isles to the Canadas, see Baehre, "Pauper Immigration to Upper Canada," 344; Elspeth Cameron, "The Historical Background," chap. 1 in Multiculturalism and Immigration in Canada: An Introductory Reader, ed. Elspeth Cameron (Toronto: Canadian Scholars' Press, Inc., 2004), 4; Marjory Harper, "Rhetoric and Reality: British Migration to Canada, 1867-1967," in Canada and the British Empire, ed. Philip Buckner (Oxford; New York: Oxford University Press, 2008), 160-62. For further reading, see also Peter E. Rider and Heather McNabb, eds., A Kingdom of the Mind: How the Scots Helped Make Canada (Montreal; Ithaca: McGill-Queen's University Press, 2006); Lucille H. Campey, "Fast Sailing and Copper-Bottomed": Aberdeen Sailing Ships and the Emigrant Scots They Carried to Canada, 1774-1855 (Toronto: National Heritage Books, 2002), 32, 55, 76; and Patrick Fitzgerald and Brian Lambkin, Migration in Irish History, 1607-2007 (New York: Palgrave Macmillan, 2008).
} 
faith. ${ }^{112}$ Although more Irish Protestants than Roman Catholics immigrated to British North America in the eighteenth-century and nineteenth-centuries, ${ }^{113}$ this was not the case in Kingston. It is not accurate that Kingston, as described by one historian, "became an Irish town in the wake of the Famine migration."114 The majority of Kingston's Irish community arrived in the first half of the nineteenth-century, therefore before the Famine years, and almost all identified as Catholic. Thanks to Bishop Patrick Phelan and the Vicar-General, Father Patrick Dollard, a detailed 1844 census of Roman Catholics in the City of Kingston exists which lists residents by street, occupation, age, and ethnicity. From this census, the City of Kingston had a total Roman Catholic population of 3,471, among them 3,087 Irish, 55 Scottish, and 329 Canadian-born. ${ }^{115}$ Comparatively, the Upper Canada Census in 1848 records the total population of Kingston as 8,416, of which 3, 238 were Catholic, and 3,609 were born in Ireland. ${ }^{116}$

\footnotetext{
112 James Lambert, "The Face of Upper Canadian Catholicism: Culture and Metropolitanism in the Establishment of the Roman Catholic Church in Upper Canada, 1800-1825," CCHA, Historical Studies 54 (1987): 13.

${ }^{113}$ Kevin Kelly, "The Irish in the Empire," in Ireland and the British Empire, ed. Kevin Kelly (Oxford; New York: Oxford University Press, 2004), 98. There has been much discussion by historians about the relative number of Roman Catholics compared to Protestants who immigrated from Ireland to British North America in the decades immediately preceding, during, and following the Famine years. For this discussion, see Jason King, "Ireland and Canada," 5-13.

${ }^{114}$ Debra L. Nash-Chambers, "In the Palm of God's Hand? The Irish Catholic Experience in Mid-Century Guelph," CCHA, Historical Studies 51 (1984): 67.

${ }^{115}$ Roman Catholic Diocese of Kingston, "Census of the Catholic population of the Mission of Kingston, Canada, taken in the months of May and June of the year 1844 by His Lordship the Right Rev'd Bishop Phelan and the Rev'd Patrick Dollard," transcription, Margaret M. Cohoe(Kingston, Ontario: Kingston Branch, Ontario Genealogical Society, 1979), 35. Note that among Kingston Canadians-born in this census there were notations for two Germans and an Italian.

${ }^{116}$ By 1848, Upper Canada had been renamed Canada West. However, the two names were used interchangeably to describe the province. For Kingston's 1848 population statistics, see Statistics Canada tables, "1848 Populations by Religion" and "1848 Populations by Birth Place" in "Upper Canada: 1824-1861," Queen's University Library, http://library.queensu.ca/data/census-1665-1871-uc. Original data from Government of Canada, Censuses of Canada, 1665 to 1871, Statistics of Canada, Volume IV (1876). It is very likely Bishop and Father Dollard's 1844 census was more accurate than the 1848 government census.
} 
Kingston's garrison had put the city on the map, but immigration and the surrounding waterways spurred its growth. The Rideau Canal system, which ends with the locks at Kingston Mills, was completed in 1832 and opened for marine traffic in 1836. ${ }^{117}$ The fortifications surrounding Kingston, including the redoubt at Fort Henry, were built between 1832 and the mid-1840s, and the City of Kingston, incorporated in 1838, served as Canada's capital from 1841 to $1844 .{ }^{118}$ Kingston's Roman Catholic Regiopolis College received its charter from the Legislature Assembly of Upper Canada in 1837 and opened in $1842 .{ }^{119}$ Queen's University, originally “The Presbyterian College at Kingston," was incorporated by the legislature in 1840, and renamed “Queen's College at Kingston" by Royal Charter in $1841 .{ }^{120}$ The Canadian Gazetteer provided this helpful summary of the professions and trades in 1846 Kingston:

One steam grist mill, four breweries, three tanneries, ten physicians and surgeons, fourteen lawyers, three foundries, steam planning machine, thirty-six dry goods and hardware stores, thirty-seven groceries, three booksellers, five druggists, two shipbuilders, one surveyor, five printers, one engraver, one dentist, ninety-four taverns, three bookbinders, one marble factory, eight boarding houses, six tallow chandlers, two coach makers, five wagon makers, eight saddlers, one veterinary surgeon, four watchmakers, one boat builder, two sail makers, ten cabinet makers, seven livery stables, five painters, ten tinsmiths, nine bakers, seven blacksmiths, five confectioners, four coopers, five stone masons, thirty-six shoemakers, twenty-nine tailors, two chair makers, four hatters, two barbers, seven butchers, two sausage makers, five ladies' schools, two do. for boys. Bank agencies, $4{ }^{121}$

\footnotetext{
${ }^{117}$ Ontario Dept. of Public Records and Archives, Historic Ontario, 57. See also Merridee L. Bujaki, "Visualizing the Rideau Canal through Early Budget Estimates, 1823-1824," Accounting History 20, no.1 (February 2015): 43-62; Katherine M.J. McKenna, ed., Labourers on the Rideau Canal, 1826-1832: From Work Site to World Heritage Site (Ottawa: Borealis Press, 2008).

${ }^{118}$ Robert W. Garcia, "The Pivot of Defence of Upper Canada: An Overview of the Structural History of Fort Henry," Ontario Archaeology no. 76, (2003): 54-63; “"This period of desperate enterprise': British Efforts to Secure Kingston from Rebellion in the Winter of 1837-1838," Ontario History 101, no. 2 (Autumn 2009): 163; George M. Betts, "Municipal Government and Politics, 1800-1850," in To Preserve \& Defend, 223-44; Ontario Dept. of Public Records and Archives, Historic Ontario, 54-57.

119 Terence J. Fay, "The Jesuits and the Catholic University of Canada at Kingston," CCHA Historical Studies 58 (1991): 60.

${ }^{120}$ Hilda Neatby, 'Queen's University: Town and Gown in 1877," in To Preserve \& Defend, 331-32.

${ }^{121}$ William H. Smith, Smith's Canadian Gazetteer: Comprising Statistical and General Information respecting all parts of the Upper Province, or Canada West... with a map of the Upper Province (Toronto: H. \& W. ROWSELL, 1846), 93.
} 
Kingston's exports included wheat and barley, as well as lumber from Ottawa, shipped via the waterways to Kingston and the United States. ${ }^{122}$ By 1846 , Kingston was a bustling town.

Kingston was the midway point between Toronto and Montréal, whether by boat or steamship along Lake Ontario and the St. Lawrence River, or overland by stage-coach or wagon. ${ }^{123}$ New York State was just across Lake Ontario, and Bytown, incorporated as the City of Ottawa in 1855, was only a short journey by steamer through the Rideau Canal. ${ }^{124}$ The Grand Trunk Railway’s first passenger train on the main line between Toronto and Montréal began in 1856 and stopped at Kingston's station on Montréal Street, and then laid more track for branch lines to Kingston a few years later. ${ }^{125}$ Whether in between cities, provinces, or countries, Kingston was a useful stopping place for travelers. $^{126}$

Kingston was not particularly diverse. The residents captured in the 1848 census were a fairly monolithic group: Kingstonians were almost entirely Caucasian, Christian, and originated from either Britain or another area of Western Europe. There were exceptions to this homogeny, however: a tiny Jewish community and a small black community were recorded in Kingston's earliest censuses.

\footnotetext{
122 Douglas McCalla, Consumers in the Bush: Shopping in Rural Upper Canada (Montreal: McGillQueen's University Press, 2015), 30; Bothwell, A Short History of Ontario, 51, 73.

${ }^{123}$ Edwin Guillet, The Pioneer Farmer and Backwoodsman, Vol. 2 (Toronto: University of Toronto Press, 1970), 41.

${ }^{124}$ Richard M. Reid, ed., The Upper Ottawa Valley to 1855 (Ottawa: The Champlain Society and Carleton University Press, 1989), xlvi.

${ }^{125}$ Nick Mika and Helma Mika, Mosaic of Kingston: An Illustrated History of the City (Belleville, Ontario: Mika Silk Screening Limited, 1969), 85; M. L. Bladen, "Construction of Railways in Canada to the Year 1885," Contributions to Canadian Economics 5 (1932): 43-46; Joseph G. Colmer, "Some Canadian Railway and Commercial Statistics," Journal of the Royal Statistical Society 51, no. 1 (March 1888): 100. ${ }^{126}$ Alan G. Green, "Immigrants in the City: Kingston as Revealed in the Census Manuscripts of 1871," in To Preserve \& Defend, 317.
} 
In 1832, legislation guaranteed Jews equal rights in Lower and Upper Canada. ${ }^{127}$ According to the 1841 census, there were five Jews in Kingston, of which only the Nordheimer brothers, Abraham and Samuel, are discussed in the historical record. ${ }^{128}$ Originally from Bavaria, the Nordheimer brothers established a successful music store where they sold sheet music and pianos. ${ }^{129}$ The brothers appear to have arrived in Kingston in 1840, and, in 1842, Abraham was hired as the Bagot family's music teacher. ${ }^{130}$ This was a very prestigious position given Sir Charles Bagot's position as the Governor-General of the Canadas. Music was central to the Notre-Dame Sisters' livelihood, and they must have been deeply appreciative of the Nordheimer brothers' expertise with pianos and the opportunity to obtain sheet music for the elite young ladies whom they sought to attract to their school and those they already taught. By 1860 , Kingston was a city known for its pianos. ${ }^{131}$

For those seeking the terminus of the Underground Railroad, British North America was perceived as a safe haven. It is clear from first-hand accounts that it was not 'the promised land' many had expected, however. In spite of Lord Simcoe's leadership as an abolitionist, "black refugees themselves had to actively solicit the metropole's support by fashioning themselves as British emancipated subjects deserving of the empire's

\footnotetext{
${ }^{127}$ William IV, Chap. LVII, "An Act to declare persons professing the Jewish religion entitled to all the rights and privileges of the other subjects of His Majesty in this Province," Provincial Statues of Lower Canada, 1832. See also B. J. Sack, History of the Jews in Canada (Montréal: Harvest House, 1965), 104-5.

${ }^{128}$ Marion E. Meyer, The Jews of Kingston: A Microcosm of Canadian Jewry? (Kingston: Limestone Press, 1983), 9-10.

${ }^{129}$ Sack, History of the Jews, 104-105, 158-159; Meyer, The Jews of Kingston, 9-17; Helmut Kallmann, "NORDHEIMER, ABRAHAM," in Dictionary of Canadian Biography, vol. 9, University of Toronto/Université Laval, 2003-, accessed August 8, 2018, http://www.biographi.ca/en/bio/nordheimer_abraham_9E.html. It is possible there were other Jews in Kingston during this period who chose not to self-identify for a variety of reasons: they no longer practiced their faith, did not feel culturally connected to Judaism, had since intermarried, or had experienced incidents of anti-Semitism and feared future persecution.

${ }^{130}$ Meyer, The Jews of Kingston, 11.

${ }^{131}$ Ibid., 11.
} 
protection and tutelage." 132 Overt racism and hostility promptly led to segregated communities. ${ }^{133}$ And despite its proximity to upstate New York, and its large population of Loyalists, Kingston had only a very small group of black settlers. Most Americans fleeing slavery instead crossed the "fluid frontier" of the Detroit borderlands. ${ }^{134}$ In her plea for her fellow black Americans to immigrate to Canada in light of the Fugitive Slave Act of 1850, Mary A. Shadd did not name Kingston as one of the suitable places for black settlement. ${ }^{135}$ This despite the famous "Jerry Rescue" of 1851, when Samuel Joseph May, an uncle of Louisa May Alcott, and other abolitionists leaders arranged for a group of men to break William McHenry (nicknamed "Jerry") out of the Syracuse police station and successfully spirited him across the border to Kingston, where he lived until his death. $^{136}$

\footnotetext{
${ }^{132}$ Ikuko Asaka, "Our Brethren in the West Indies": Self-Emancipated People in Canada and the Antebellum Politics of Diaspora and Empire," The Journal of African American History 97, no. 3 (Summer 2012), 220. While promoting Uncle Tom's Cabin, a Canadian juvenile periodical undermined their own attempts at sympathy by the following commen: "It is hoped that the sympathy of our Canadian readers will be awakened in behalf of this unfortunate people, who, while they possess many repulsive traits, are our brethren ..." See "Uncle Tom's Cabin: or Life Among the Lowly," July 1852, Vol. 1, No.1, in The Maple Leaf: A Juvenile Monthly Magazine, Vol. I and II (Montréal: E.H. Lay by J.C. Becket, 1853), 4. George Hendrick and Willene Hendrick, Black Refugees in Canada: Accounts of Escape During the Era of Slavery (Jefferson, N.C.: McFarland \& Co., 2010), 17-18,163-166. ${ }^{133}$ Jasanoff, "The Other Side of Revolution," 208. See also Hendrick and Hendrick, Black Refugees in Canada, 10-11, 18.

134 J. Blaine Hudson, "Canada," in Encyclopedia of the Underground Railroad (Jefferson, N.C.: McFarland \& Co., 2006), 54; Jacqueline Tobin and Hettie Jones, From Midnight to Dawn: The Last Tracks of the Underground Railroad, (New York: Anchor Books, 2008), 84; Hendrick and Hendrick, Black Refugees in Canada, 17-18,163-166. For a dedicated study of the Detroit borderland, see Karolyn Smardz Frost and Veta Smith Tucker, eds., A Fluid Frontier: Slavery, Resistance, and the Underground Railroad in the Detroit River Borderland (Detroit: Wayne State University Press, 2016).

${ }^{135}$ Mary E. Shadd, A Plea for Emigration, or, Notes of Canada West, ed. Richard Almonte (1852, reprint; Toronto: Mercury Press, 1998). Kingston is only mentioned in reference to the Provincial Penitentiary and the number of black people convicted -375 individuals convicted in 27 years. See S.G. Howe, The Refugees of Slavery in Canada West: Report to the Freedmen's Inquiry Commission (Boston: Wright \& Potter, Printers, 1864; New York: Arno Press, New York Times, 1969), 84.

${ }^{136}$ Eve LaPlante, Marmee \& Louisa: The Untold Story of Louisa May Alcott and her Mother (New York: Simon and Shuster Paperbacks, 2013), 169; Richard M. Reid, African Canadians in Union Blue: Enlisting for the Cause in the Civil War (Vancouver: UBC Press, 2014), 24.
} 
When Charles Dickens visited Kingston in 1842, after time spent in Toronto and before continuing by steamboat to Montréal, he described Kingston in distinctly unflattering terms: "The latter place, which is now the seat of government in Canada, is a very poor town, rendered still poorer in the appearance of its marketplace by the ravages of a recent fire. Indeed, it may be said of Kingston, that one half of it appears to be burnt down, and the other half not to be built up." ${ }^{137}$ In an aesthetic sense, Charles Dickens' visit was a combination of poor timing and bad luck for Kingston. A massive fire, fueled by stored gunpowder, destroyed much of the downtown in April of 1840, and the city's infrastructure was slowly being rebuilt using quarried limestone. ${ }^{138}$ Like Dickens, Millicent Mary Chaplin, who had left England to join her husband on his military posting to Canada, was unimpressed by Kingston when she visited a few years earlier. Chaplin wrote in her travel diary on Monday, September 17, 1838: "Walked about Kingston into Court, in hopes of hearing Col. Dundas' trial - towards the fort - to the Dock Yard. I don't admire Kingston at all -embarked in the Dolphin at 3 P.M. saw the Eclipse when amidst the 1000 Islands - delighted with the Scenery there - ."139

Others during the same period viewed the town in a more positive light. From the extensive "discourse of emigration" there were many voices who supplied images for interested readers and prospective travelers. ${ }^{140}$ In Robert MacDougall's 1841 travel guide, originally published in Gaelic for an audience of Highland Scots planning to emigrate, he described Lake Ontario and the closeness of Oswego in upstate New York

\footnotetext{
${ }^{137}$ Charles Dickens, American Notes for General Circulation (New York: J. Winchester, 1842), 227.

138 Osborne and Swainson, Kingston, 99.

${ }^{139}$ Millicent Mary Chaplin, Drawing on the Land: The New World Travel Diaries and Watercolours of Millicent Mary Chaplin, 1838-1842, ed. Jim Burant (Manotick, Ontario: Penumbra Press, 2004), 53.

${ }^{140}$ Errington, "British Migration and British America," 150.
} 
just across the Lake, the Rideau Canal and its shipping traffic, the availability of quality arable land, especially wheat, the fishery, and the noticeably large quantity of limestone which had been used to good effect in Kingston: "The result is that there are nice, large buildings, and neat, clean streets, and on the whole, it is a very decent little town." ${ }^{141}$ As was common in much of Canada West, the rural countryside outside Kingston was mainly tenancy-based. ${ }^{142}$ Unlike British, Irish, Scottish, and Welsh tenancies though, many farmers could hope in their lifetime to purchase the land they rented. In 1840, Kingston was a city that promised much to its British and European settlers. The Sisters of the Congrégation de Notre-Dame would encounter a city of hopeful residents in the early winter of 1841 .

\section{Education and State Activity in Canada West: Catholic Schooling in Kingston}

Leaving Catholic Lower Canada for Protestant Kingston was not necessarily an easy decision for any of the sisters. As one John Francis McGuire wrote about Lower Canada and the Irish Catholic of Montréal on an 1868 visit from Ireland, "In no part of the British Provinces of North America... is there a more Catholic city, where his religion is respected." 143 Gaulin flattered, cajoled, prayed, and pleaded with the sisters to join him in Kingston, and was not above having the Bishop of Montréal, Ignace Bourget, petition the sisters on his behalf. Bourget urged the Congrégation de Notre-Dame not to agree until they had considered every detail and drawn up a contractual agreement that was fair

\footnotetext{
${ }^{141}$ Robert MacDougall, The Emigrant's Guide to North America, ed. Elizabeth Thompson (1841, reprint, Toronto: Natural Heritage Books, 1998), 46.

${ }^{142}$ Catharine Anne Wilson, Tenants in Time: Family Strategies, Land, and Liberalism in Upper Canada, 1799-1871 (Montreal: McGill-Queen's University Press, 2009), 44.

${ }^{143}$ Cited in Rosalyn Trigger, "Clerical Containment of Diasporic Irish Nationalism: A Canadian Example from the Parnell Era” in Irish Nationalism in Canada, ed. David A. Wilson (Montreal; Kingston: McGillQueen's University Press, 2009), 84-85.
} 
to both sides. After much discussion and a congregational vote, two sisters subsequently arrived in Kingston on November 21, 1841. Within four days, they had enrolled 12 daystudents and lessons had begun. Even Protestants were impressed. ${ }^{144}$

Most records from the early community no longer exist due to fire, but the Congrégation de Notre-Dame may have benefited in a unique way from the British elite who wanted their daughters enrolled in a school with a curriculum dedicated to the cultural and academic pursuits of French women. The Congrégation de Notre-Dame could only manage rented quarters. The house left to them by Bishop Macdonell was far from ready that November. Instead, they had to make do with three meagre rooms in a building across from the Kingston market that they shared with noisy families and, when in session, the town council. ${ }^{145}$ The sisters' rental quarters were reportedly so impoverished that, “on seeing their premises... they began to envy Mother Bourgeoys's stable." ${ }^{146}$ Not everyone was supportive of the Kingston Foundation though. Father Joseph-Vincent Quiblier, a Sulpician and Superior of the Petit séminaire de Montréal, pointedly told the sisters they were making a mistake leaving for Kingston. The Sulpicians had persuaded the Congrégation de Notre-Dame to teach Irish and English girls in Montréal, and Quiblier did not want to lose any of his precious teachers. ${ }^{147}$

\footnotetext{
${ }^{144}$ Bishop Remigius Gaulin to Sister Sainte-Gertrude, 4 January 1842, Kingston, in Soeur Sainte-Henriette Lemire-Marsolais, Histoire de la Congrégation de Notre-Dame de Montréal: Troisième partie, XIX siècle, Volume VIII: 1840-1849 (Montréal: Maison-Mère de la Congrégation de Notre-Dame de Montréal, 1941), $156-57$.

${ }^{145}$ Lemire-Marsolais, Histoire de la Congrégation de Notre-Dame de Montréal, 156.

${ }^{146}$ Andrée Désilets, "HUOT, MARIE-FRANÇOISE, Sainte-Gertrude," in Dictionary of Canadian Biography, vol. 7, University of Toronto/Université Laval, 2003-, accessed July 17, 2018, http://www.biographi.ca/en/bio/huot_marie_francoise_7E.html; Lemire-Marsolais, Histoire de la Congrégation de Notre-Dame de Montréal, 155.

${ }^{147}$ Louis Rousseau, «QUIBLIER, JOSEPH-VINCENT », dans Dictionnaire biographique du Canada, vol. 8, Université Laval/University of Toronto, 2003-, consulté le 17 juill. 2018, http://www.biographi.ca/fr/bio/quiblier_joseph_vincent_8F.html.
} 
Roman Catholic sisters were known for their teaching, and the Congrégation de Notre-Dame, like other French congregations, had been teaching girls in Montréal since the seventeenth-century. ${ }^{148}$ Teaching sisters tended to open schools in major urban centres where they could attract students and donors. ${ }^{149}$ According to the Congrégation de Notre-Dame, reflecting retrospectively fifty years after their departure for Kingston, Bishops Bourget and Gaulin "had in view the salvation and sanctification of many of the Catholic inhabitants who might otherwise have grown lukewarm and careless in matters of religion, by reason of their frequent intercourse with Protestants to whose schools they were obliged to send their children." 150 There were several seminaries for young ladies in mid-nineteenth century Kingston, ${ }^{151}$ and the Notre-Dame sisters offered only one choice, but they had an academy boarding school for elite girls, and a free school for poor girls. This was the common model for French teaching congregations. ${ }^{152}$

Before drawing up contractual agreements that specified the responsibilities of both parties, however, protracted negotiations took place. Sisters had to determine if there were any sisters interested in leaving Montréal and gain their bishop's support. Ignace Bourget had been installed as coadjutor to Bishop Jean-Jacques Lartigue of the Montréal Diocese in 1837 , then succeeded Lartigue after his death in 1840 , and remained Montréal's bishop until his resignation in $1876 .{ }^{153}$ Bishop Bourget worked to transform

\footnotetext{
${ }^{148}$ McGuinness, Called to Serve, 4.

149 Danylewycz, Light, and Prentice, "The Evolution of the Sexual Division of Labour in Teaching," 108.

${ }^{150}$ Montreal Archives of the Congrégation de Notre-Dame, 310.150.4, "Memorial of the Golden Jubilee, Convent C.N.D., Kingston, Province, Ont., 1841-1891: Conclusion,” no page numbers.

${ }^{151}$ Smith, Smith's Canadian Gazetteer, 93; Daily British Whig (1850), 12 Jan 1852, "Miss Quill's Seminary," 2; Daily British Whig (1850), 13 Jan 1852, "Education," 1.

${ }^{152}$ Sarah Curtis, Civilizing Habits: Women Missionaries and the Revival of French Empire (Oxford; New York: Oxford University Press, 2010), 59.

${ }^{153}$ Gilles Chaussé and Lucien Lemieux, "LARTIGUE, JEAN-JACQUES," in Dictionary of Canadian

Biography, vol. 7, University of Toronto/Université Laval, 2003-, accessed January 10, 2018,
} 
the diocese of Montréal through his austere pronouncements, backed by the Church's pastoral and political power, and affirmed by the British authorities. ${ }^{154}$ Bourget severely limited the ways young people could date and restricted the harmless fun or "letting loose" the sisters had previously enjoyed, but he did encourage the sisters' mission to Kingston. ${ }^{155}$

After the Rebellions of 1837-38 and the 1839 publication of the Report of Lord Durham on the Affairs of British North America, Canadian leaders sought to secure their authority. Adopting new educational policies and establishing a universal public-school system was one method to ensure social order in Canada West. ${ }^{156}$ Up to this point, the Provincial Government's intervention in people's daily lives was much less significant than the role played by families, neighbours, and religious foundations. Children were usually homeschooled, if they received an education at all, and people's social networks, rather than the government, provided a 'safety-net. ${ }^{, 157}$ Sisters, by virtue of their place in the Church, had large social networks that they tapped into for assistance. Despite the

http://www.biographi.ca/en/bio/lartigue_jean_jacques_7E.html; Philippe Sylvain, "BOURGET, IGNACE," in Dictionary of Canadian Biography, vol. 11, University of Toronto/Université Laval, 2003-, accessed January 10, 2018, http://www.biographi.ca/en/bio/bourget_ignace_11E.html. See also Philippe Sylvain, "Ignace Bourget," The Canadian Encyclopedia, Historica Canada, 1985-, accessed January 10, 2018, https://www.thecanadianencyclopedia.ca/en/article/ignace-bourget/.

${ }^{154}$ Bruce Curtis, "Pastoral Power, Sovereignty and Class: Church, Tithe and Simony in Quebec" Critical Research on Religion 5, no. 2 (2017): 151-169.

${ }^{155}$ Ollivier Hubert, "Ritual Performance and Parish Sociability: French-Canadian Catholic Families at Mass from the Seventeenth to the Nineteenth Century," in Households of Faith, ed. Christie, 59; Marta Danylewycz, Taking the Veil, 49.

${ }^{156}$ Historical perspectives differ as to whether education was used as a means for the government to enforce social order or political control. For example, see Chad Gaffield, "Children, Schooling, and Family Reproduction in Nineteenth-Century Ontario," The Canadian Historical Review 72, no. 2 (1991): 157-191. For a comprehensive history of education in early Canada, including Ontario, see Paul Axelrod, The Promise of Schooling: Education in Canada, 1800-1914 (Toronto: University of Toronto Press, 1997).

${ }^{157}$ For a discussion of the state's involvement in Upper Canada, as compared to post-1841, see Johnson, In Duty Bound, 242-56. For a discussion of social networks, see Françoise Noël, Family Life and Sociability in Upper and Lower Canada, 1780-1870: A View from Diaries and Family Correspondence (Montreal: McGill-Queen's University Press, 2003), 246, 258. 
introduction of a public-school system, the Congrégation de Notre-Dame continued to use their social and religious network to attract students to their schools.

Coming, as they did from Montréal, the controversies swirling around the issue of state education were not new to the Sisters of the Congrégation de Notre-Dame. The Education Commissioner of Lower Canada, Arthur Buller, had hoped Bishop Lartigue and his fellow bishops would agree to a religiously mixed education system for the sake of national unity. ${ }^{158}$ After all, as Allan Greer's study of the Lower Rebellion has illustrated, Bishop Lartigue had issued a pastoral letter to his diocese stating that no Catholic could join the revolt of the subversive Patriots, thereby throwing his loyal support behind the British Government. ${ }^{159}$ Indeed, since the Conquest, Canada's Catholic Church had a long history of supporting the British government. ${ }^{160}$ But Buller would be disappointed, as would his English counterparts in Upper Canada. In 1838, the bishops in Quebec "explicitly denounced the project of a civil religion as the basis of national unity," and Lartigue wrote to a colleague that "with their general education, they will

\footnotetext{
${ }^{158}$ Bruce Curtis, Ruling by Schooling Quebec: Conquest to Liberal Governmentality - A Historical Sociology (Toronto: University of Toronto Press, 2012), 360-64.

${ }^{159}$ Allan Greer, The Patriots and the People: The Rebellion of 1837 in Rural Lower Canada (Toronto: University of Toronto Press, 1993), 233. Loyalty to the British crown was shown by Father Joseph-Vincent Quiblier, a native of France and a Sulpician Superior, who provided the British Calvary with the route to St. Eustache, and where successfully put down the 1837 Rebellion. See Elinor Senior, "The Provincial Calvary in Lower Canada, 1837-50," The Canadian Historical Review 57 no. 1 (March 1976): 8.

160 "The Fenian Campaign," 4 June 1870, The Tablet: A Weekly Newspaper and Review, London, England 35, no. 1573, 706; Mark G. McGowan, "Michael Power, the Catholic Church, and the Evangelization of the First Nations Peoples of Western Upper Canada, 1841-1848," in Irish and Scottish Encounters with Indigenous Peoples: Canada, the United States, New Zealand, and Australia, ed. in Graeme Morton and David A. Wilson (Montreal \& Kingston: McGill-Queen's University Press, 2013), 196. Historian Howard Adams credited the Church's loyalty for provision of Separate Schools in the Education Act of 1842. See Howard Adams, "Roots of Separatism," History of Education Quarterly 8, no. 1 (Spring, 1968): 35-43.
} 
also give their students a general religion, which they will hammer into their heads, that is to say an absurdity." 161

Appointed Chief Superintendent of Schools from 1844 until his retirement in 1876, Egerton Ryerson was a remarkably able administrator who successfully implemented Ontario's free, non-sectarian, universal public elementary school system and standardized curriculum. ${ }^{162}$ Canada West's first Common Schools Act was passed in 1841, and the three following decades saw several School Acts repealed, amended, and passed in the legislature. ${ }^{163}$ Bishop Gaulin of Kingston had actively petitioned the Legislative Assembly on behalf of his Catholic parishioners in Canada West to be considered in the forthcoming School Act. ${ }^{164}$ Where Ryerson believed integration of all religious denominations was the most positive aspect of universal schooling, this was of serious concern to Catholic leaders.

A Separate School system was created to serve Canada West's Roman Catholic minority under the 1841 School Act. ${ }^{165}$ The School Law Improvement Act of 1871 ensured that education was entirely free for all public school pupils, and mandated compulsory

\footnotetext{
${ }^{161}$ Cited in Bruce Curtis, "State of the Nation or Community of Spirit? Schooling for Civic and EthnicReligious Nationalism in Insurrectionary Canada," History of Education Quarterly 43, No. 3 (Autumn 2003), 342. See also Bruce Curtis, The Politics of Population: State Formation, Statistics, and the Census of Canada, 1840-1875 (Toronto: University of Toronto Press, 2001), 8; Bruce Curtis, "Monitorial Schooling, "Common Christianity," and Politics: A Transatlantic Controversy," in Transatlantic Subjects, ed. Nancy Christie, 273.

162 R. D. Gidney, "RYERSON, EGERTON," in Dictionary of Canadian Biography, vol. 11, University of Toronto/Université Laval, 2003-, accessed July 13, 2018, http://www.biographi.ca/en/bio/ryerson_egerton_11E.html; Alison Prentice, The School Promoters: Education and Social Class in Mid-Nineteenth Century Upper Canada (Don Mills, Ont.: Oxford University Press, 1999), 13-14.

${ }^{163}$ Bumstead, "The Consolidation of British North America," 62. See also Bruce Curtis, "Class Culture and Administration: Educational Inspection in Canada West" in Colonial Leviathan: State Formation in MidNineteenth-Century Canada, ed. Allan Greer and Ian Radforth (Toronto: University of Toronto Press, 1992), 103-33.

${ }^{164}$ J. Harold Putman, Egerton Ryerson and Education in Upper Canada (Toronto: W. Briggs, 1912), 175.

${ }^{165}$ Ibid., 175; Mark A. Noll, A History of Christianity in the United States and Canada (Grand Rapids, Michigan: W.B. Eerdmans, 1992), 272.
} 
attendance for children between the ages of seven and twelve for a minimum of four months. ${ }^{166}$ When instituting compulsory attendance, legislators were aware children were needed at home for chores, childcare, farm work, or even earning supplemental wages. ${ }^{167}$ In his Report on a System of Public Elementary Instruction for Upper Canada, Ryerson laid out his core belief regarding the positive social return to be gained from education, stating: "such a system of general Education amongst the people is the most effectual preventative of pauperism, and its natural companions of misery and crime." ${ }^{\prime 68}$ Under the Common Schools Act of 1841, every child had an equal right to the same level of elementary education.

Ryerson produced a prodigious number of writings during his tenure and oversaw a bureaucratic system that produced an overwhelming number of statistics, reports, and correspondence. ${ }^{169}$ An uproar over Kingston's Catholic schools' response to the Common School Trustees' inspection figures into part of that correspondence. Beginning in the 1853 school year, the Sisters of the Congrégation de Notre-Dame and the Christian Brothers' were on the rolls as Separate Schools and in receipt of a portion of the public

\footnotetext{
${ }^{166}$ Egerton Ryerson; Ontario Department of Education, Ontario Education Report for 1870: with an exposition of the provisions of the School Law Improvement Act of 1871, illustrated by examples of recent school legislation in various countries of Europe and America: being a reprint of the first part of the general report of the Chief Superintendent of Ontario, for 1870 (Toronto: Hunter, Rose \& Company, 1871), 32. See also Karen Stanworth, Visibly Canadian: Imaging Collective Identities in the Canadas, 1820-1910 (Montreal \& Kingston: McGill-Queen's University Press, 2014), 70; Marta Danylewcyz and Alison Prentice, "Teachers' Work: Changing Patterns and Perceptions in the Emerging School Systems of Nineteenth- and Early Twentieth-Century Central Canada," Labour/Le Travail 17 (Spring 1986): 65; Christopher Clubine, "Motherhood and Public Schooling in Victorian Toronto," in Schooling in Transition: Readings in Canadian History of Education, ed. Sara Z. Burke and Patrice Milewski (Toronto: University of Toronto Press, 2012), 115-26.

${ }^{167}$ John Bullen, "Hidden Workers: Child Labour and the Family Economy in Late Nineteenth-Century Urban Ontario," Labour/Le Travail 18 (Fall 1986): 163-87.

${ }^{168}$ Egerton Ryerson, Report on a System of Public Elementary Instruction for Upper Canada (Montreal: Lovell and Gibson, 1847), 10.

${ }^{169}$ Bruce Curtis, "Textual Economies and the Presentation of Statistical Material: Charts, Tables and Texts in 19th Century Public Education," Scientia Canadensis 29, no. 1 (2006): 12-17.
} 
funds, which Protestant trustees did not agree with in principle because they were run by

religious orders who refused the usual inspections and did not use the standard

textbooks. ${ }^{170}$ When Rev. J. Malcom Smith, Chairman of Kingston's Board of Trustees,

set out to inspect both the Christian Brothers and Congrégation de Notre-Dame schools in

1854, he was asked to return another day, and unceremoniously thrown out of the sisters'

school. He described his experience to Ryerson:

I then went to the Nuns' school. A lay female teacher to whom I first applied leave to see the school, referred me to a Nun who was teaching some classes in an adjoining apartment; she, after hesitating a little, permitted me to remain, and brought up one of the classes for examination. I had not been long in, when an older Nun, I believe the superioress of the institution, entered and asked me what right I had to be in the school; I explained to her who I was, and in what capacity I came; she told me it was no matter, and that I had no right to visit the school until I had previously asked and obtained leave to do so, at least two days previously. ${ }^{171}$

This scene is illustrative of the power religious sisters had over their own establishments and over secular men. It also highlights the difficulty sisters had in transitioning to the public system after having had control over their Kingston school for more than a decade.

Teaching was still considered a mainly female profession, and the sisters were in safe territory. ${ }^{172}$ When Rev. Smith complained to the Board of School Trustees, an unnamed Roman Catholic priest, also a trustee member, placed the sisters and brothers on par with

\footnotetext{
170 Table 189: "Table shewing [sic] the number of Protestant and Roman Catholic Separate Schools in Upper Canada," Egerton Ryerson et al., Copies of Correspondence between the Chief Superintendent of Schools for Upper Canada, and Other Persons, on the Subject of Separate Schools (being a continuation of the return laid before the House, and printed on the 17th September 1852) (Toronto: Lovell \& Gibson, 1855), 256. For a report that states Kingston had 12 Common Schools at year-end on January $31^{\text {st }}, 1859$, see Egerton Ryerson, ed., "Kingston Educational Items," Journal of Education, Upper Canada 12, no. 3 (Toronto: March 1859), 46; Rev. J. Malcom Smith to Egerton Ryerson, 24 February 1854, "No. 27: The Kingston Board of School Trustees to the Chief Superintendent," Copies of Correspondence between the Chief Superintendent, 79.

${ }^{171}$ Rev. J. Malcom Smith to Egerton Ryerson, 8 March 1854, "No. 29: The Kingston Board of School Trustees to the Chief Superintendent," in Copies of Correspondence between the Chief Superintendent, 82.

172 Marta Danylewycz, Beth Light, and Alison Prentice, "The Evolution of the Sexual Division of Labour in Teaching," 81-109.
} 
one another, "gravely" informing Smith "...that if I wished to get into either of the schools I had nothing to do but come to him and he would afford me the requisite facilities, adding, that he was not surprised I had been refused admittance."173 The sisters were paid by public funds until December of 1854, when they were stripped of their Common School status, and seemingly had it restored for the following school year of 1855-1856 due to Catholic Trustee votes. ${ }^{174}$

Perhaps Ryerson's most pointed exchanges were with the second Roman Catholic Bishop of Toronto, Armand-François-Marie de Charbonnel. ${ }^{175}$ Born in France and an ultramontane, Bishop de Charbonnel's years as Bishop of Toronto were marked by discord over the Separate Schools issue. ${ }^{176}$ Although Bishop Phelan and the Bishop of Bytown signed onto Bishop de Charbonnel's petition submitted to the Legislative Assembly in 1854 calling for the same funding and legislation for Catholic education as was available in Canada East, ${ }^{177}$ it is clear that Ryerson placed the blame on de Charbonnel, as he provided various examples of Kingston's success with Catholic Separate Schools. ${ }^{178}$ Phelan realized that much of the discussion surrounding the School

\footnotetext{
173 Ibid., 82.

${ }^{174}$ Rev. J. Malcom Smith to Egerton Ryerson, 21 December 1854, No. 33, "The Kingston Board of School Trustees to the Chief Superintendent," in Copies of Correspondence between the Chief Superintendent of Schools, 88; Begnal, "Sisters of the Congregation de Notre Dame," 32.

${ }^{175}$ Murray W. Nicolson and John S. Moir, "CHARBONNEL, ARMAND-FRANÇOIS-MARIE DE," in Dictionary of Canadian Biography, vol. 12, University of Toronto/Université Laval, 2003-, accessed July 13, 2018, http://www.biographi.ca/en/bio/charbonnel_armand_francois_marie_de_12E.html; Gidney, "RYERSON, EGERTON," http://www.biographi.ca/en/bio/ryerson_egerton_11E.html.

${ }^{176}$ McGowan, Michael Power, 226.

177 John George Hodgins, The Legislation and History of Separate Schools in Upper Canada: From 1841, Until the Close of the Reverend Doctor Ryerson's Administration of the Education Department of Ontario in 1876: Including Various Private Papers and Documents on the Subject (Toronto: William Briggs, 1897), 81.

${ }^{178}$ Egerton Ryerson to John A. Macdonald, 2 April 1855, No. 6: "The Chief Superintendent to the Honourable Attorney General MacDonald," in Egerton Ryerson et al., Law of Separate Schools in Upper Canada, by the Roman Catholic Bishops and the Chief Superintendent of schools: Being the First Part of the Correspondence (Toronto: Lovell \& Gibson, 1855), 22-39.
} 
Act was political maneuvering, with Ryerson and the Attorney-General, John A.

Macdonald, trying to placate the clergy, secure Catholic votes, and maintain political harmony. Bishop Michael Power, de Charbonnel's short-lived predecessor, had been of a similar mindset to Ryerson. He had positive relationships with Protestant leaders and strongly supported the Common Schools Act. ${ }^{179}$ Outraged over the lack of funding for Separate Schools, de Charbonnel proclaimed that Catholics risked damnation supporting the Common Schools, and in good conscience all Catholics must financially support the Separate School system. ${ }^{180}$ Judging by the numbers, only a small percentage of Catholics heeded, and even a non-Catholic like Ryerson knew declaring support for the Common School system a mortal sin was a step too far. ${ }^{181}$ In Kingston, the majority of Catholics continued to send their children to the common schools.

A political appointee, Ryerson was also a Methodist minister and, convinced in his beliefs, he designed a school system based on "the Christian religion, the maintenance of the British connection, and the balanced constitution." 182 He openly aimed to inculcate students with a Christian belief-system and British values. ${ }^{183} \mathrm{He}$ achieved this by

\footnotetext{
${ }^{179}$ Mark G. McGowan, Michael Power: The Struggle to Build the Catholic Church on the Canadian Frontier (Montreal: McGill-Queen's University Press, 2005), 3, 225, 257-258; William J. Smyth, Toronto, the Belfast of Canada: The Orange Order and the Shaping of Municipal Culture (Toronto: University of Toronto Press, 2015), 123.

${ }^{180}$ Bishop de Charbonnel to Egerton Ryerson, 1 May 1852, Correspondence between the Roman Catholic bishop of Toronto and the chief superintendent of schools, on the subject of separate common schools in Upper Canada: with an appendix, containing the provisions of the law and the general regulations regarding religious instruction in our common schools, the regulations of the commissioners of national education in Ireland: also, a consideration of the question of religious instruction in connection with our system of public instruction, from the chief superintendent's annual report for 1851 (Toronto: T.H. Bentley, 1853), 14.

${ }^{181}$ Egerton Ryerson to Bishop de Charbonnel, 12 May 1852, Correspondence between the Roman Catholic bishop of Toronto and the chief superintendent of schools, 15-19.

182 Goldwin S. French, "Egerton Ryerson and the Methodist Model for Upper Canada," in Historical Essays on Upper Canada: New Perspectives, ed. J.K. Johnson and Bruce G. Wilson (Ottawa: Carleton University Press, 1989), 550. See also Egerton Ryerson, "The Story of My Life": Being Reminiscences of Sixty Years' Public Service in Canada, ed. John George Hodgins (Toronto: William Briggs, 1883).

${ }^{183}$ Ryerson, Report on a System of Public Elementary Instruction for Upper Canada, 9, 60-61, 63; Chad Gaffield, Language, Schooling, and Cultural Conflict: The Origins of the French-Language Controversy in
} 
standardizing the curriculum through the use of specific textbooks. In 1846, he recommended the "National Irish Series" for schools in Canada West due to their nonsectarian, religious neutrality, the series having been previously approved by both Irish Catholic and Protestant factions, as well as cost and imperial connection. ${ }^{184}$ American textbooks were specifically targeted as anti-British, and as the Irish National Series was introduced, a ban on all foreign textbooks came into effect on January 1, 1847. ${ }^{185}$

The Irish curriculum championed by legislators behind Ryerson's Education Act of 1846 demonstrated the transnationality of the old world and the new. In Ireland's nineteenth-century national school system, the reading materials were gendered, the role of men and women described in terms of "complementary spheres," with the female sphere considered naturally subordinate. ${ }^{186}$ The texts maintained what religious congregations had always taught, which "conveyed a world view that emphasised respectful deference to hierarchy, the justness of a divinely sanctioned social structure and the appropriateness of the modest awards." ${ }^{187}$ Part of a deeply patriarchal system, the Congrégation de Notre-Dame sisters undoubtedly supported and upheld these same views in their classrooms.

Ontario (Kingston, Ont.: McGill-Queen's University Press, 1987), 12-16; Neil McDonald, "Egerton Ryerson and the School as an Agent of Political Socialization" in Schooling in Transition: Readings in Canadian History of Education, ed. Sara Z. Burke and Patrice Milewski (Toronto: University of Toronto Press, 2012), 39-56; James H. Love, "Cultural Survival and Social Control: The Development of a Curriculum for Upper Canada's Common Schools," Histoire sociale/Social History 15, no. 30 (November 1982): 382.

${ }^{184}$ Ryerson, Report on a System of Public Elementary Instruction for Upper Canada, 173-74; Love, "Cultural Survival and Social Control," 372-74.

${ }^{185}$ Love, "Cultural Survival and Social Control," 374-75, 379.

${ }^{186}$ John Logan, "The Dimensions of Gender in Nineteenth-Century Schooling," in Gender Perspectives in Nineteenth-Century Ireland, ed. Margaret Kelleher and James H. Murphy (Dublin, Ireland; Portland, Orgeon: Irish Academic Press, 1997), 45.

${ }^{187}$ Ibid. 
Regardless of ethnic background, creed, or socio-economic status, colonial parents throughout Canada West were equally anxious for their children to be educated. ${ }^{188}$ Education was a sure route to respectability in a settler society. Initially, there were a small number of Indigenous children who attended common schools, ${ }^{189}$ but Ryerson asserted they should be educated differently and separately from common school students in a system of Industrial Schools. ${ }^{190}$ The School Act which expressly authorized separate schools based on religion was amended in 1850 to include Article 19, which to the dismay of many parents, authorized the formation of racially segregated schools. ${ }^{191}$

Some of the most notable changes to the School Acts were amendments inserted to satisfy vocal Catholic leaders, especially Toronto's Bishop de Charbonell. Ryerson's 1858 Special Report on the Separate School Provisions ${ }^{192}$ outlined the many conflicts with Catholic Bishops, which mainly centred on the number of separate schools allowed per school district, taxation, funding, and inspections. ${ }^{193}$ These issues were almost entirely resolved by the subsequent School Acts, passed between 1855 and 1871. By

\footnotetext{
${ }^{188}$ From an excerpt in Benjamin Drew, The Refugee: A North-side View of Slavery (Boston: John P. Jewett and Company, 1856), cited in Hendrick and Hendrick, Black Refugees in Canada, 145.

${ }^{189}$ Robert Carney, "Aboriginal Residential Schools Before Confederation: The Early Experience," CCHA, Historical Studies 61 (1995): 18.

${ }^{190}$ Truth and Reconciliation Commission of Canada, They Came for the Children: Canada, Aboriginal Peoples, and Residential Schools (Winnipeg, Man.: Truth and Reconciliation Commission of Canada, 2012; Saint-Lazare, Quebec: Canadian Electronic Library, 2012), 6.

${ }^{191}$ J. George Hodgins, Historical and Other Papers and Documents Illustrative of the Educational System of Ontario, 1853-1868 (Toronto: L. K. Cameron, 1911), 213, also quoted in Kristin McLaren, "We had no desire to be set apart: Forced Segregation of Black Students in Canada West Public Schools and Myths of British Egalitarianism," Social History/Histoire Sociale 37, no. 73 (2004): 38; Howe, The Refugees of Slavery in Canada West, 50-53; Guillet, The Pioneer Farmer and Backwoodsman, 183-84. Schools for indigenous children were not discussed in this Act.

${ }^{192}$ Egerton Ryerson, Special Report on the Separate School Provisions of the School Law of Upper Canada, and the Measures which have been Adopted to Supply the School Sections and Municipalities with School Text Books, Apparatus and Libraries (Toronto: John Lovell, 1858).

${ }^{193}$ Axelrod, The Promise of Schooling, 39-41.
} 
1882, the separate school system even had its own inspectors. ${ }^{194}$ Men and women

religious were integrated into Ontario's Separate School system as teachers, and were lauded by the English Catholic press, who in 1870 called for the same system to be implemented in England. ${ }^{195}$ Conflicts aside, the provincial government and the Catholic Church compromised to provide a successful education system.

By mid-century, Kingston was a rapidly developing city. Canadian society was shifting towards a new liberalism that would put it in direct conflict with the Catholic Church. When first elected in 1846, Pope Pius IX was politically moderate, even described as a liberal, but his experiences during the Revolutions of 1848 and with Italian nationalism caused him to adopt an increasingly conservative approach. ${ }^{196}$ Pontiff from 1846 to 1878 , Pius IX was the architect of many nineteenth-century reforms, but is best remembered for convening the First Vatican Council and his pronouncements on socialism, science, and Catholic doctrine that enshrined the concepts of the Immaculate Conception and papal infallibility. ${ }^{197}$ Fearing social liberalism and political reforms, Pope Pius came down hard on ideological dissension in the nineteenth-century. ${ }^{198}$ His every

\footnotetext{
${ }^{194}$ Robert Stamp, The Historical Background to Separate Schools in Ontario (Toronto: Queen's Park; Ministries of Colleges and Universities, 1985), 8; John Millar, The Educational System of the Province of Canada (Toronto: Warwick \& Sons, 1893), 5, 24, 79.

195 "Our educational claim," 19 March 1870, The Tablet: A Weekly Newspaper and Review, London, 35, no. 1562, 350; "Catholic Poor School Committee," 7 May 1870, The Tablet: A Weekly Newspaper and Review, London, 35, no. 1569, 590.

${ }^{196}$ Owen Chadwick, The Popes and European Revolution (Oxford: Oxford University Press, 1980), 60910.

${ }^{197}$ Joe Holland, Modern Catholic Social Teaching: The Popes Confront the Industrial Age, 1740-1958 (New York, N.Y.; Mahwah, N.J.: Paulist Press, 2003), 86-104; Maureen Fiedler and Linda Rabben, eds., Rome Has Spoken: A Guide to Forgotten Papal Statements and How They Have Changed Through the Centuries (New York: Crossroad, 1998) 15, 19, 23, 29, 34, 48, 85, 105, 201. See also Joseph I. Sirven, et al., "Seizures Among Public Figures: Lessons Learned from the Epilepsy of Pope Pius IX," Mayo Clinic Proceedings 82, no. 12 (December 2007): 1535. Pope Pius IX's absolute power is best captured in a single phrase: 'Roma Locuta Est - Causa Finita Est - Rome has spoken - the cause is finished.'

${ }^{198}$ Gene Burns, "The Politics of Ideology: The Papal Struggle with Liberalism," American Journal of Sociology 95, no. 5 (March 1990): 1125, 1148; Hans Küng, The Catholic Church: A Short History (New York: Modern Library, 2003), 159-67. See also Michael Joseph Schuck, That They Be One: The Social Teaching of the Papal Encyclicals, 1740-1989 (Washington, D.C.: Georgetown University Press, 1991), 1-
} 
pronouncement was felt across the Catholic world, each of his letters being read out or conveyed during Sunday Mass to parishioners. Bishops and priests took up his call to conservatism, and sisters fell in line. The Catholic Church's transnationalism was a force to be reckoned with and, as demonstrated by Ryerson and Bishop Charbonnel's very public correspondence, so too was the Church's extremely loyalty and fidelity to Pope Pius IX.

Coupled with their religious, political, and temporal goals, the bishops envisioned transforming Kingston's Catholic population into respectable citizens who were wellintegrated into the city's Protestant majority and wider British North American society. During this period of great social reform and institution building, "respectability" intersected with gender, ethnicity, class and socio-economic status, and religion. ${ }^{199}$ Kingston's bishops were motivated by religious and political goals when they sought out three congregations to provide sacramental preparation, educational instruction, and medical care. With a reputation for excellence, nuns and sisters possessed the necessary influence and respectability to further their charitable works in Kingston. ${ }^{200}$ If a bishop's position in pre-Confederation Canada included a mixture of religious and political advocacy, it was sisters and nuns who supplied the labour.

Significantly, sisters' work could extend outside what was considered the traditional domain of women if the sisters themselves remained within their Rule and Customary and the bounds of nineteenth-century respectability. By carrying out their

44; Gene Burns, The Frontiers of Catholicism: The Politics of Ideology in a Liberal World (Berkeley: University of California Press, 1992).

${ }^{199}$ Roberts, In Mixed Company, 126; Janet Miron, Prisons, Asylums, and the Public: Institutional Visiting in the Nineteenth Century (Toronto: University of Toronto Press, 2011), 85.

${ }^{200}$ Morrow, Persons of Colour and Religious at the Same Time, 59; Magray, The Transforming Power of the Nuns, 12. 
charism, the sisters strove to serve the Catholic community and to bring about changes that demonstrated that the Catholics of Kingston were equal to their Protestant neighbours. To do this, nuns and sisters established Catholic institutions as spaces where residents, patients, orphans, and students were molded in the image of a "good religious": prayerful, industrious, modest, honest, and obedient. In this way, sisters were able to fulfil the original goals of their 'foundresses', their vision for Kingston, and further the interests of their Bishop(s) and the Provincial Government. 


\section{Chapter 2: Vowed Women Religious and Their Work}

Upon their respective arrivals in 1841,1845 , and 1861, each group of sisters had a role to play in the collective mission of building the Catholic community of Kingston. The Congrégation de Notre-Dame were teachers, the Religious Hospitallers of Saint Joseph were nurses, and, as "servants of the poor," the Sisters of Providence provided practical assistance to the neediest members of the local community. Because sisters also needed to secure a reliable income for themselves, their supplemental work sometimes extended beyond their traditional apostolates to what historian Jane Errington has termed “a women's economic world.",201

This chapter will explore the different kinds of labour performed by sisters and examine how their work served to fulfil their religious vocations. Determining how the sisters negotiated the deeply gendered spaces of society and church will frame this discussion. The sisters indirectly confronted the notion of "separate spheres" by virtue of their religious state, which allowed them to carve out a space traditionally reserved for men. Still, gendered occupational divisions were apparent in the work assigned to them by Kingston's bishops. In Joan Wallach Scott's recent discussion of the power of the "idealized representation" of the separate domains men and women inhabited in the nineteenth century, Scott reminds us that "idealized norms still matter, not only in the expectations set for individual subjects, but because they set the terms for law, politics, and social policy." 202 The nineteenth-century gender norms that relegated women to domesticity provide a crucial backdrop to any discussion of women's religious life.

\footnotetext{
${ }^{201}$ Errington, Wives and Mothers, 208.

202 Joan Wallach Scott, Sex and Secularism (Princeton: Princeton University Press, 2018), 32.
} 
The sisters and nuns missioned to Kingston to provide Catholic social services were also highly entrepreneurial. As discussed in Chapter 1, the sisters had to contend with the social secular expectations of the period whether in private or in public, and especially when carrying out their work. Elizabeth Smyth has referred to the stages of religious life as "one of dual formation: as a religious and as a professional." ${ }^{203}$ Religious life was first and foremost rigorous religious formation, through which sisters sought "To know, love and then imitate Jesus Christ, more perfectly than ordinary Christians and with this view to add the practice of the evangelical counsels to that of the precepts; to aim at reaching perfection by safer and shorter paths than the rest of Christians, is the essence and the object of religious life."204 Selecting a religious community and seeking admission were the first steps on the long road to final vows. Gaining skills for a profession, such as teaching or nursing, was secondary. Indeed, sisters could not select their work once they entered religious life; instead, work was assigned to them as needed. Whether manual or administrative, all work was considered meaningful when seen through the lens of religious life.

\section{Entering the Convent: Vows, Prayers, and Offices}

Upon taking religious vows, Catholic nuns entered into a spiritual union with Jesus Christ and subsequently came under the protection of the Church hierarchy. The goal for all religious was to work together in harmony, providing mutual practical, spiritual, and emotional support while carrying out the Church's mission. Life as a sister or nun, whether within the convent walls or outside of them, was highly regulated.

\footnotetext{
203 Elizabeth Smyth, "Professionalization Among the Professed," 238.

${ }^{204}$ Manual of the Religious Hospitallers of Saint Joseph (Mans, France: 1839; Montréal: English trans., Hôtel-Dieu,1896), 3.
} 
Importantly, the convent provided a space outside immediate male control where Sisters could define and establish their own social order.

A woman passed through four distinct stages of formation: postulancy, the novitiate, temporary vows, and final profession. Postulants were not committed to the congregation but were active inquirers and lived alongside the novices. The 'postulancy' or candidacy stage lasted 6 months and was a period of discernment. If she was successful, she then entered the novitiate and received the habit of a novice. ${ }^{205}$ The traditional ceremony of taking the veil, a new religious name, and making vows stressed a sister's new identity as a consecrated virgin. ${ }^{206}$ During this period of continuing discernment, postulants and novices performed manual labour and learned the different offices from the professed sisters. Prayerful obedience, silent recollection, and a deep commitment to one's work were the hallmarks of a good religious. If a woman was capable of being a sister, then she was capable of any profession.

According to Nancy Christie and Michael Gauvreau, by the 1840s two-thirds of Canada's Catholic priests were from a farming background, about one-sixth were the sons of artisans, and only a few had fathers in a skilled profession. ${ }^{207}$ In other words, they were much like the majority of their parishioners and the women who entered religious life. In her study of nineteenth and early twentieth-century American women religious, Margaret Susan Thompson argued that religious life "mirrored the secular world," which was a positive because it was "humanizing and constructive," as well as a negative

\footnotetext{
205 Ibid.

${ }^{206}$ Danielle Rives, "Taking the Veil: Clothing and the Transformation of Identity," trans. Carol E. Harrison, Journal of the Western Society for French History 33 (2005): 465-86. Women who entered the Religious Hospitallers of Saint Joseph, unlike the majority of religious congregations, typically did not take a religious name.

${ }^{207}$ Nancy Christie and Michael Gauvreau, Christian Churches and their Peoples, 1840-1965: A Social History of Religion in Canada (Toronto: University of Toronto Press, 2010), 26.
} 
because it invited "dissension and conflict into religious life." ${ }^{208}$ Few were the convents, abbeys, and monasteries where sisters were not riven by worldly ideas of social status and power constructs. Between 1841 and 1874, the years of this study, only Kington's Sisters of Providence did not separate sisters by educational background and family socioeconomic status. They were the exception. The Congrégation de Notre-Dame sisters and Hôtel-Dieu nuns had their roots in seventeenth-century New France, and with no changes made to their Rule in the intervening years, they maintained an elitist structure until late in the nineteenth-century.

The convent was not only a sacred place for women committed to the consecrated life, but a space removed from "the male gaze." In only a few prescribed circumstances were men permitted "ingress" (entrance) into the Sisters' living quarters. In Periculoso, the 1298 apostolic constitution, Pope Boniface VIII strengthened the rules of monastic enclosure for women, making it necessary to seek permission of the Ordinary (the Bishop) for "egress" or its opposite, "ingress," for entering the cloister. ${ }^{209}$ Doctors were admitted to visit the sick, priests to administer the final sacraments to the gravely ill and dying, and workmen to paint, build, or fix what the Sisters could not do themselves. Collectively known as the "last rites," in the nineteenth-century a priest would only have been called when a sister was near death. The priest would have said the prayers and administered the final sacraments, with the other sisters gathered around. After the priest said the ritual prayers, the dying person made a final confession, followed by receipt of

\footnotetext{
${ }^{208}$ Margaret Susan Thompson, "Sisterhood and Power: Class, Culture, and Ethnicity in the American Convent," Colby Library Quarterly 25, no. 3 (September 1989): 150.

209 John P. Beal, James A. Coriden, and Thomas J. Green, eds., New Commentary on the Code of Canon Law (Mahwah, N.J.: Paulist Press, 2000), 833.
} 
the Eucharist (Viaticum). "Extreme Unction" was then administered, the 'final anointing' of the individual with oil. ${ }^{210}$

A woman interested in the Religious Hospitallers of Saint Joseph either entered as a vocal sister, who could be elected to positions of authority, or as a sister who performed domestic work. Lay or domestic sisters could not be elected to positions of authority, and were instead "admitted to fill the more laborious employments and to spend their whole lives in double subordination." 211 The Manual of the Religious Hospitalers of Saint Joseph explained the need for such a distinction in this way: "Although all men are equal in His eyes, God has seen fit to establish in this world different conditions quite necessary to maintain the spirit of dependence, without which it would be impossible to live in peace. This order must be preserved not only among people who live in the world but also among those who dwell in cloisters. For this reason there are $[\mathrm{sic}]$ in religious houses, choir sisters and domestic sisters." 212 These occupational divisions were representative of the Church's European medieval history, but also reflected socio-economic differences, and power. ${ }^{213}$

For entrance into the Congrégation de Notre-Dame women had two options: Soeur or Soeur domestique (also referred to as bonsecours or conversae soeur). Sisters were teachers and could be elected, and the Conversae Soeur were responsible for domestic duties. All were to belong to respectable families and be above reproach. Similarly, Religious Hospitallers of the Hôtel-Dieu entered as either a Choir Sister

\footnotetext{
${ }^{210}$ Lawrence S. Cunningham, An Introduction to Catholicism (Cambridge: Cambridge University Press, 2009), 114.

${ }^{211}$ Ibid.

${ }^{212}$ Manual of the Religious Hospitalers of Saint Joseph, 73.

${ }^{213}$ For a discussion of choir and lay sisters, see Silvia Evangelisti, Nuns: A History of Convent Life, 14501700 (Oxford: Oxford University Press, 2007; 2013), 30-33; Thompson, "Sisterhood and Power,” 151-152.
} 
('Hospitaler') or as a Lay Sister, also referred to as a Domestic Sister. ${ }^{214}$ In these instances, choir sisters, like teaching sisters, entered with a dowry, were generally better educated as they were required to read, speak, and sing in Latin, nurse, run the hospital pharmacy, and make administrative decisions. Lay sisters, on the other hand, were generally less educated, could not read or speak Latin, entered with little or no dowry, and were responsible for the domestic tasks, such as meal preparation, cleaning, and tending to the heavy work on the wards. Despite the inequality of a sister's labour on behalf of the congregation, all were consecrated religious and were to treat one another with respect.

As discussed in Chapter 1, all three congregations left their Montréal Motherhouses for Kingston. For the Congrégation de Notre-Dame, Kingston was only a mission and the sisters could be recalled to Montréal or sent elsewhere at any time. Every Hôtel-Dieu monastery was autonomous, but the sisters missioned to the new Kingston foundation retained close ties with the Hôtel-Dieu Montréal. One the day of their departure, the original four nuns sent to Kingston made an 'Act of Protestation' in September of 1845 declaring each sister's fidelity to the congregation and the Montréal house (Fig 2.1 and Fig. 2.2). The Sisters of Providence left Montréal with the intention to establish a separate diocesan congregation under the authority of Kingston's Bishop Horan in 1861. The first group of Sisters of Providence retained ties with the Montréal Motherhouse and were to be recalled after seven years. However, Bishop Horan's actions

\footnotetext{
${ }^{214}$ Within the Catholic Church, the laity or a lay person refers to people or an individual who is not ordained or part of a religious order or congregation. In this chapter 'lay sister' and 'domestic sister' will be used interchangeably as they were at the time. Lay sisters are not to be confused with lay servants or "perpetual boarders" who were lay women that did not take vows. They lived in the monastery but outside the cloister.
} 
ensured their ties were severed two years earlier. This gave Horan a large measure of control over the sisters and how they organized their work. These crucial distinctions within each congregation determined the number of sisters available for an apostolate and whether sisters could accept certain types of work. Staffing was a continual source of contention between the sisters and Bishop Horan.

The results of the elections for the Hôtel-Dieu nuns missioned to Kingston, held on October 29, 1845, and written about in the Annals by Sister Latour illustrate the remarkable variety of work sisters performed and how they divided it amongst themselves as 'offices': 215

Rev. Mother Bourbonniere - Superior, Mistress of Novices, Pharmacy Officer, Manciple of the Community and Hospital, will distribute the work.

Sister Latour - Assistant, Hospitaller of the male and female wards, companion to the Pharmacy, Monitress of the Superior, Officer of the Orphan's ward, Secretary of the Chapter.

Sister Davignon - Bursar, Sacristan, Portress, bell ringer.

Sister Emélie - Cook, Shoemaker, Laundress, Gardener, at the poultry yard, altar bread baker, etc., etc.

Sister Emélie Barbarie, originally from St-Eustache, Québec, entered the Hôtel-Dieu (Montréal) as a Lay Sister in 1824. The annalist's description of Sister Emélie reminds readers of the expected behaviour of lay sisters: "It is true that everyone got along with the kind and dear Sister Emélie, she was so polite to the Sisters and so condescending to all, thoughtful and so charitable, she was a constant example of all the virtues of a perfect Lay Sister, humble, discreet, and most fervent. In a word she possessed the true spirit of

215 84.1, 13, Sr. Claire Latour, "Translation of the Annals of our House of Kingston 1845 - to - (February 3, 1891), 1, St. Joseph Region Archives, Kingston. 
her holy state." ${ }^{216}$ The annalist's words have been translated directly from French, 'condescendre à ce que,' to 'condescending' in English. Unfortunately, the original meaning of the phrase has been lost in translation. The intention of the annalist, Sister Latour, had been to describe Sister Emélie's deference to the other sisters. She meant Sister Emélie would condescend to the other sisters, that is, to freely and agreeably complete the humblest tasks for them. This again mirrored the nineteenth-century secular world, where humility was encouraged as a feminine quality, especially for women in domestic roles. Interesting too is how the annalist, Sister Latour, referred to Sister Emélie by her first name rather than by her last name as was customary for the choir sisters. In Figures 2.1 and 2.2, the distinction can be seen through their signatures.

\footnotetext{
${ }^{216}$ Ibid.; Sister Loretta Gaffney, RHSJ, Provincial/Regional Archivist, and Rodney Carter, Archivist for the St. Joseph Region, "Barbarie, Emilie 1804-1866," Dictionary of Biography of the Religious Hospitallers of Saint Joseph Region: Lives of the Members of the Saint Joseph Region from the Beginnings of the Houses that make up this Region 1845-2014 (updated December 12, 2014), B2. Note from the RHSJ Dictionary of Biography: Emilie was sometimes spelled Emélie.
} 


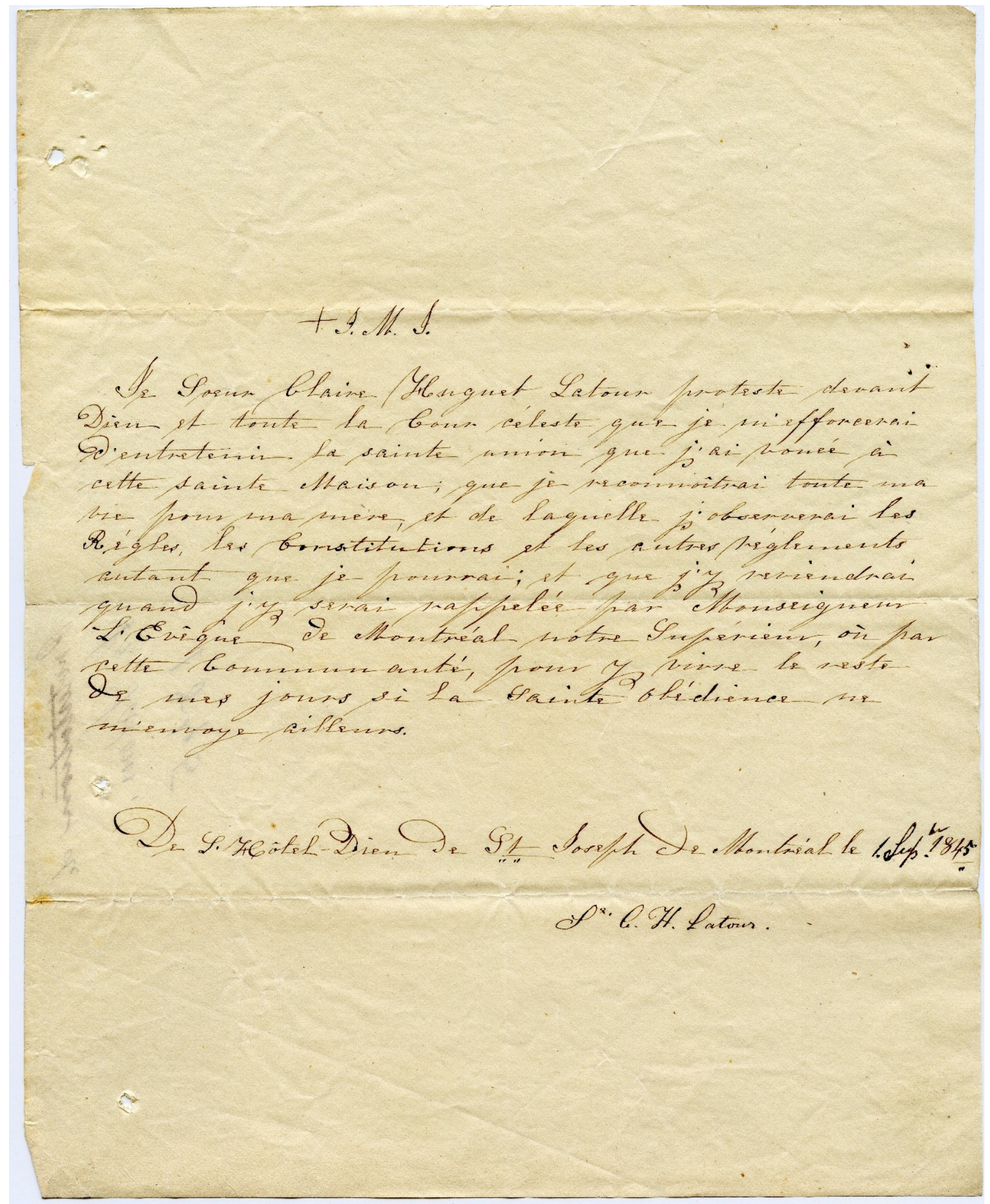

Fig. 2.1 Sr. Claire Latour's 'Act of Protestation' declaring her allegiance to the Hôtel-Dieu de Montréal, dated 1 September 1845. Note how she signs only her initials and last name. 


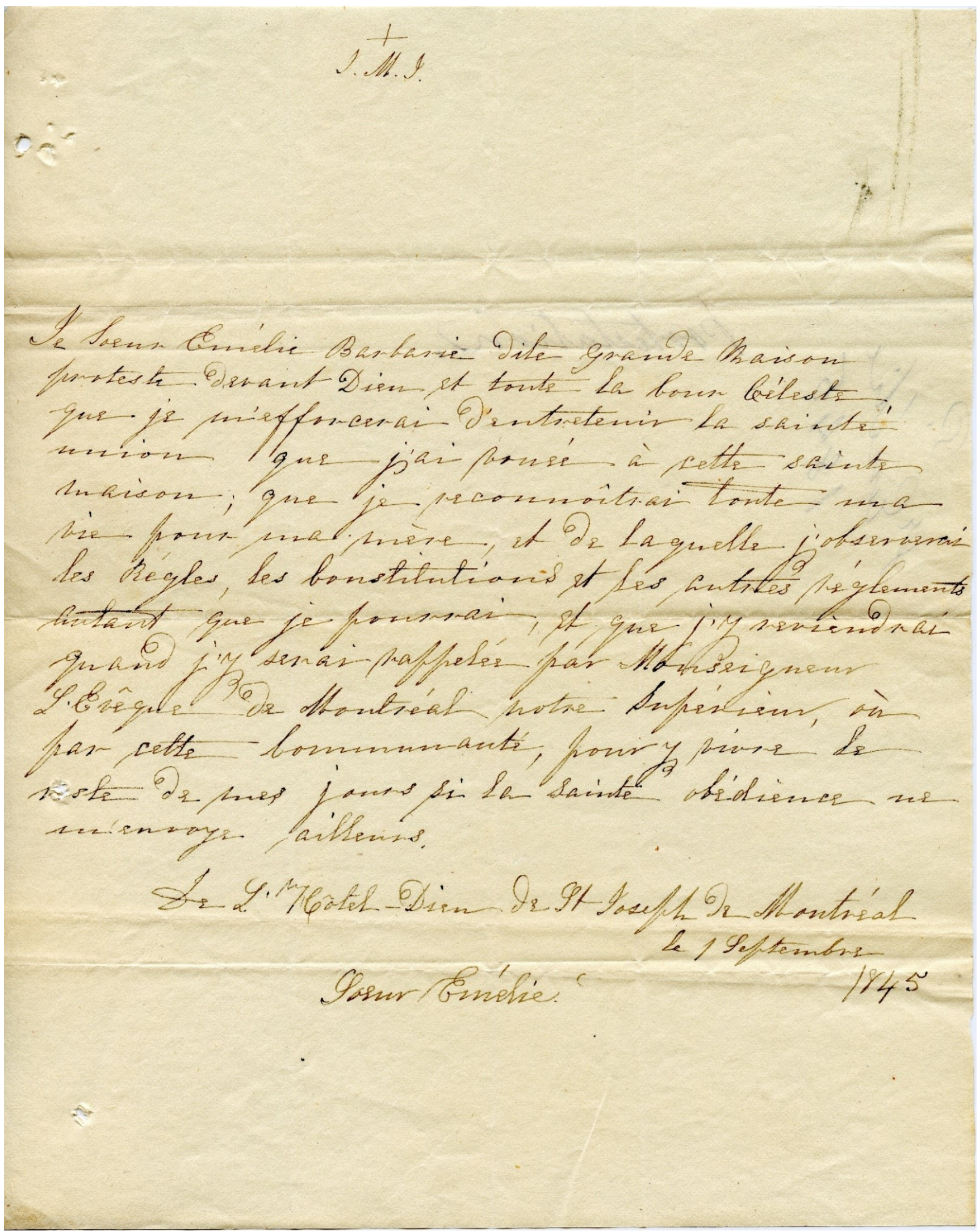

Fig. 2.2 Sr. Emélie Barbarie's 'Act of Protestation' declaring her allegiance to the Hôtel-Dieu de Montréal, dated 1 September 1845. 
If a woman had been a domestic servant before she entered, she entered as a lay sister. She also had to be strong and healthy to persevere in such a difficult lifestyle. However, one's social status was not rigidly static. Fluidity was possible when circumstances warranted it. There are two recorded instances of women who entered the Hôtel-Dieu Kingston as domestic sisters and, before making profession, left the community and re-entered as choir sisters. First was Lucy MacDougald and later Jane McTague, both from Kingston. Jane McTague entered the Hôtel-Dieu Kingston community on July 21, 1853 as a Domestic Sister. Staying only three weeks, Jane left the community on August 11, 1853. Received again, Jane re-entered the Hôtel-Dieu as a Choir Sister on June 5, 1855, but after two months left for good. ${ }^{217}$

Lucy MacDougal, born in 1823 to a Scottish father, Owen MacDougal, and an Irish mother, Ann McLennan, was the first woman from Kingston and Upper Canada (Canada West) to enter the Hôtel-Dieu Kingston on November 18, 1845 as a Lay Sister.

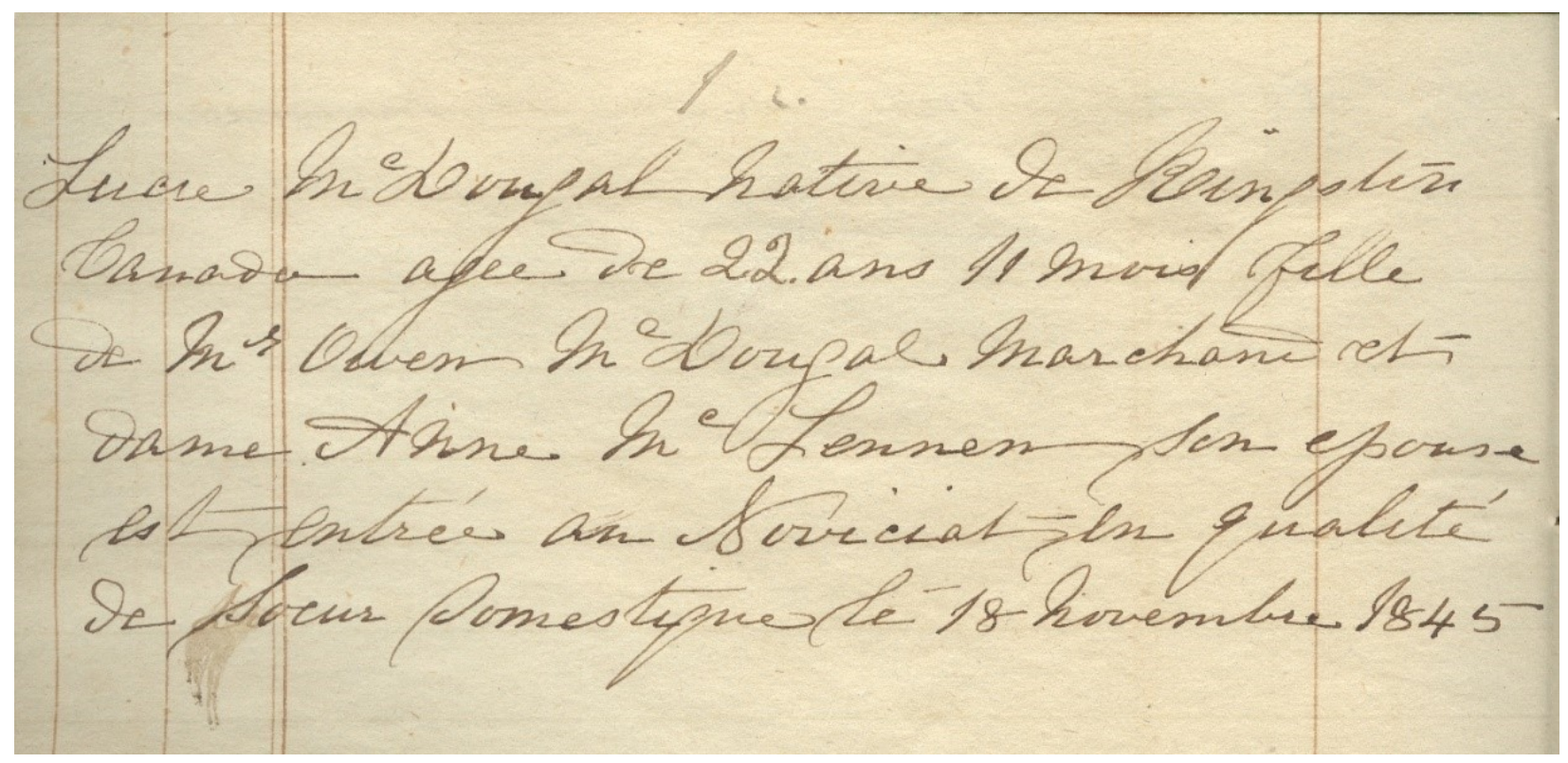

Fig. 2.3 Lucy McDougal's record of entrance to the Kingston Hôtel-Dieu, dated 18 November 1845.

217 “Jane McTague (lay)," RHSJ list of entrances for Kingston, 2. Jane McTague left the community a second, and final time, on August 7, 1855. 
Reverend Mother Bourbonniere, who served double duty as Mother Superior and Mistress of Novices, entrusted Lucy to Sister Emélie, “....as a help and also to teach her to work. Our good Sister Emélie spoke no English and the Postulant spoke no French, still they understood one another, each one named the articles in her own tongue, and made signs to one another the way of doing things and they got along very well." The language barrier was the same one many Catholics faced in Kingston, and one the bishops were eager to overcome. As a mother or female relative would teach a daughter, neighbour, niece or servant her duties, Lucy became Sister Emélie's apprentice to prepare her for the role of "housekeeping and household production" within the convent. ${ }^{218}$ The postulant stage was the period when a woman gained the necessary skills for religious life, and the Mistress of Novices judged whether the entrant had the aptitude and was a suitable fit for her particular congregation. Like an apprentice in her first year, the discerning postulant could quickly be dismissed or leave on her own terms. Evidently Mother Bourbonniere saw great potential in Lucy. When due to illness Lucy could longer keep up with the demands of being a domestic sister, she was allowed to re-enter the cloister on June 5, 1846 in the rank of Choir Sister. ${ }^{219}$

For nuns and sisters, prayer was always considered the most consequential work and the way in which they invested their days with meaning. ${ }^{220}$ The spiritual lives of men and women religious revolved around the Roman Catholic Church's Liturgy of the Hours, also referred to as the Divine Office (Officium Divinum), and of feasting and

\footnotetext{
${ }^{218}$ Noël, Family Life and Sociability, 82-101.

219 "Translation of the Annals of our House of Kingston 1845 - to - (February 3, 1891), 1; RHSJ list of entrances for Kingston, 1, 18; "MacDougald, Lucy 1823-1898," Dictionary of Biography of the Religious Hospitallers of Saint Joseph Region, M2.

${ }^{220}$ Cunningham, An Introduction to Catholicism, 156.
} 
fasting throughout the liturgical seasons of Advent, Christmas, Lent, the Paschal

Triduum, Easter, and Ordinary Time. ${ }^{221}$ The complete Liturgia Horarum consisted of “canonical hours," prayers fixed at three hour increments: Matins (also referred to as Vigils, Nocturn, or the "Night Office”), Lauds, Prime, Terce, Sext, None, Vespers, and Compline. $^{222}$ Generally the Liturgy of the Hours were sung every three hours, although exact times depended on the congregation, but began with Matins at midnight. Matins and Lauds could also be prayed together at the same time. ${ }^{223}$ The Hours consisted of a cycle of multiple hymns, psalms, canticles, scripture readings, antiphons, prayers and blessings. The structure of a congregation and its "charism" determined a sister's prayer life. The candidate's choice of order or congregation depended on the prayer life, the community's chosen work, and what aspects of the community's spirit most attracted the candidate. The congregation a woman selected would determine her life's path, work, and the amount of silent reflection throughout her day.

The Religious Hospitallers of Saint Joseph's Ceremonial provides directions for sisters gathered to sing Lauds, Vespers, and Compline, and the "Little Hours" of Prime, Terce, Sext, and None; they were to be "said in a simple tone of recitation." 224 Nursing in

\footnotetext{
${ }^{221}$ Anscar J. Chupungco, OSB, Handbook for Liturgical Studies, Volume V: Liturgical Time and Space (Collegeville, Minn.: Liturgical Press, 2000); M. Cathleen Kaveny, "Billable Hours and Ordinary Time: A Theological Critique of the Instrumentalization of Time in Professional Life," Loyola University of Chicago Law Journal 33, no.1 (2001): 173-220. The Roman Breviary, the book of prayers of the Divine Office, the Divine Office, and the Liturgy of the Hours are all terms that can be used interchangeably to describe the same selection of prayers.

${ }^{222}$ Stanislaus Campbell, FSC, From Breviary to Liturgy of the Hours: The Structural Reform of the Roman Office, 1964-1971 (Collegeville, Minn.: Liturgical Press, 1995), 2; Phyllis Tickle, The Divine Hours, Vol. II: Prayers for Autumn and Wintertime (New York: Doubleday: 2000), ix-xviii.

${ }^{223}$ For reference, see Anne M. Field, ed., The Monastic Hours: Directory for the Celebration of the Work of God and Directive Norms for the Monastic Liturgy of the Hours (Collegeville, Minn.: Liturgical Press, $2000,2^{\text {nd }}$ edition).

224 "First Part, Ceremonies of the Divine Office, Chapter 2, Article 3: Ceremonies of the Office" in Ceremonial for the use of the Religious Sisters of St. Joseph after the Rule of Saint Augustin, 18-26. The Ceremonial is comprised of minute descriptions of when and where to stand, sit, and kneel during the Liturgy of the Hours.
} 
the 1800 s came with a heavy workload and busy schedule, and it is possible with so few sisters running the hospital that Bishop Phelan dispensed the cloistered nuns from reciting the Little Hours. ${ }^{225}$ Such a dispensation would have allowed the Choir Sisters to get enough sleep to balance their demanding work, maintain a level of continuity in caring for patients, as well as attending Mass and prayers, which would have still included the Morning Prayer of praise (Lauds), the Evening Prayer of thanksgiving (Vespers), and Night Prayer (Compline). ${ }^{226}$ With so few sisters, however, parts of the prayers were not sung as they would have been in a larger group of sisters. Compline was prayed before retiring to bed and doubled as nightly preparation for a holy death. When the Hôtel-Dieu Choir Sisters were in meditation, singing the Office, at Mass, or eating, the Lay Sisters would care for the patients on the hospital wards. This was often a crushing burden not minimized in the Customary: "Should her duties overtax her strength when there is no help at hand, she is then to consider that God is bestowing a double grace and is lavishing His favours on her; she will deem it a precious time of spiritual harvest, and she will take to herself the words of the Gospel: 'Whatsoever thou shalt spend over and above, I at my

\footnotetext{
${ }^{225}$ For reasons of practicality, diocesan bishops could be empowered by the pope to provide dispensations in instances where such dispensations did not contravene Church laws and contributed to the "spiritual good." The sixteenth-century Corpus Iuris Canonici, a collection of non-codified canon laws issued by Pope Gregory VIII, was in force throughout the nineteenth-century. See John J. Coughlin, Canon Law: A Comparative Study with Anglo-American Legal Theory (Oxford; New York: Oxford University Press, 2011), 35, 46-47; David L. D'avray, "Stages of Papal Law," Journal of the British Academy 5 (2017): 3759. The codification of canon law was raised at the first Vatican Council to Pope Pius IX, see A. Keogh, S.J., "The Codification of Canon Law," Journal of Comparative Legislation and International Law 10, no. 1 (1928): 14-32. For an example of a request for dispensation from the praying the breviary, see Richard Shaw, John Dubois: Founding Father, The Life and Times of the Founder of Mount St. Mary's College, Emmitsburg; Superior of the Sisters of Charity; and Third Bishop of the Diocese of New York (Yonkers, New York: United States Catholic Historical Society, 1983), supra 7, 182. For an understanding of changes to the laws surrounding dispensations, see John M. Huels, "Categories of Dispensable and Indispensable Laws," Studia Canonica 39, 1/2 (2005): 41-73; George P. Graham, "The Powers of Bishops in Recent Documents [notes]," Jurist 28, no. 4 (1968): 425-48.

${ }^{226}$ For a discussion of the Liturgy of the Hours, including an example of dispensation from prayers in cloistered religious communities, see Isabelle Arnulf, Agnès Brion, Michel Pottier, and Jean-Louis Golmard, "Ring the Bell for Matins: Circadian Adaptation to Split Sleep by Cloistered Monks and Nuns," Chronobiology International 28, no. 10 (2011): 930-941.
} 
return will repay thee.",227 The Congrégation de Notre-Dame and Sisters of Providence were neither cloistered nor contemplative monastic communities and were therefore only required to pray the 'Major Hours.' Punctuated by spiritual, intellectual, and manual labour, silence was equally integral to sisters' lives.

The periods of silence which occurred throughout a sister's day between her work, prayers, and recreation, unless speaking was strictly necessary in case of an emergency or special permission had been granted by the Mother Superior, were intended to provide moments focused solely on God. The Congrégation de Notre-Dame's Customary was clear about the necessity of silence: "Comme le silence est une disposition absolument nécessaire pour obtenir la récollection intérieure; et que c'est par sa pratique continuelle que les âmes bienheureuses, qui font l'honneur et le modèle des Communautés, ont été si étroitement unies a Dieu, les Sœurs suivant leur exemple, seront exactes au silence."228 At night during "Grand Silence," when speaking was absolutely prohibited by all religious congregations, silence was kept after Compline and examen, and not broken until Lauds and Mass the following morning.

Due to gendered expectations, the rules for cloistered male religious were starkly different than those of women religious. ${ }^{229}$ In female cloistered communities such as the Hôtel-Dieu, there was an additional role for extern sisters who served as the "tourrière." The tourrière was the portress of the convent. She quite literally "turned the gate." Extern sisters were appointed to interact with the public. The tourrière opened the outer door to

\footnotetext{
${ }^{227}$ The Customary and Little Rules of the Religious Hospitallers of the Congregation of St. Joseph, 319. See also Chapter IV: Domestic Sister, Manual of the Religious Hospitalers of Saint Joseph, translation approved by the Ordinary (RHSJ, France: 1839; trans., RHSJ, Montreal: 1896), 78.

${ }_{228}^{28}$ Règlements de la Congrégation de Notre-Dame (Bureau des Mélanges Religieux: Montréal, 1846), 48, 700.010-001, CND Archives.

${ }^{229}$ Beal, Coriden, and Green, eds., New Commentary on the Code of Canon Law, 833.
} 
receive guests or items, and extern sisters were also permitted to leave the grounds of the monastery to serve the congregation. ${ }^{230}$ In 1847 , with catastrophe at their doors, the Hôtel-Dieu nuns cared for typhus victims outside their hospital and monastic enclosure. It must have been a surprising sight. For many Catholics and non-Catholics alike, it would have been the first and only time they interacted with a cloistered nun in a public space. ${ }^{231}$ In this instance of leaving the monastery, referred to as "egress," the nuns had been given the express written permission of Bishop Phelan. ${ }^{232}$ Only by remaining within the bounds of the Church's male authority were the Hôtel-Dieu nuns allowed to serve Kingston's neediest outside their home.

\section{'Black '47': The Year of Famine, Sickness, Typhus, and Death}

In Canadian history, 1847 is best remembered for the arrival of 109,680 Irish emigrants to Canada. ${ }^{233}$ For those fleeing the ongoing economic depression and Great Famine ravaging Ireland, 1847 would bring even greater misfortune in the form of Ricksettia prowazekii: typhus. ${ }^{234}$ Typhus is spread by body lice which "can transmit the

\footnotetext{
${ }^{230}$ For a discussion about the role of the extern sister, see Evangelisti, Nuns, 49-53.

231 "Cloister refers both to the law which regulates the separation of religious from those outside the religious house and also to the actual space (rooms, buildings, gardens, walkways, etc.) set aside for the exclusive use of the religious." Beal, Coriden, and Green, eds., New Commentary on the Code of Canon Law, 833.

${ }^{232}$ Ibid. See also Nancy Bauer, "Vultum Dei Quaerere: New Norms for Nuns," The Jurist: Studies in Church Law and Ministry 76, no. 2 (2016): 381.

${ }^{233}$ For the figure of 109,680 Irish emigrants to Canada, see Brian S. Osborne, "The Cemeteries of the Midland District of Upper Canada: A Note on Mortality in a Frontier Society," Pioneer America 6, no. 1 (January 1974): 51. The exact figure of the number of Irish immigrants seems ever-changing. Pauline Jackson states there were 98, 485 Irish emigrants to Canada, "Women in 19th Century Irish Emigration," The International Migration Review 18, no. 4, Special Issue: Women in Migration (Winter 1984): 1005. Others provide more approximate estimations. According to Franca Iacovetta, over 100, 000 Irish emigrants arrived in Canada, "The Irish in Nineteenth Century Canada: Class, Culture, and Conflict" in A Nation of Immigrants: Women, Workers, and Communities in Canadian History, 1840s-1960s, ed. Franca Iacovetta, Paula Draper, and Robert Ventresca (Toronto; Buffalo: University of Toronto Press, 1998), 3-4. ${ }^{234}$ The Famine lasted from 1845 to 1852 , years when potato crops were killed by a blight, and Irish men, women, and children died in record numbers. For a detailed study of the Irish Famine, see John Crowley, William J. Smyth, and Michael Murphy, eds.; Helen Bradley, GIS consultant; Tomás Kelly, editorial
} 
disease to humans for up to 10 days" and a variety of gruesome symptoms are frequently

followed by severe complications and, for many, death:

Sickness typically begins around a week after the louse bite, with fatigue and a bad headache or backache. Soon the patient begins to appear pale and absent, and his or her reflexes fail. Around the fifth day, red circles pop out on the shoulders, torso, and arms resembling tiny jewels embedded in the skin. ...For a week or more, a severely ill patient will lie muttering and inert, with sporadic flashes of anger or frustration accompanied by spastic movements, incontinence, and loss of bowel control. Temperatures can rise to 108 degrees Fahrenheit; the heart beats at 120 beats per minute. ${ }^{235}$

From the spring to fall of 1847, a typhus epidemic swept across Eastern and Central Canada, carried across the Atlantic by Irish immigrants.

For many, their immune systems were already at great risk from malnourishment or the early stages of starvation, and the long voyage and often poor conditions aboard the ships only intensified the risk of contracting dysentery and typhus. ${ }^{236}$ Historically, typhus epidemics have occurred during periods of war or in its aftermath, when people are grouped together and most physically susceptible. ${ }^{237}$ The conditions in Ireland and the resulting mass migration created similar conditions to those observed during wartime: poverty, famine, displacement of huge numbers of people and insufficient public health

assistant, Atlas of the Great Irish Famine, 1845-52 (New York: New York University Press, 2012). See also C.J. Griffin, "The Great Famine in Colonial Context: Public Reaction and Responses in Britain before the 'Black '47,"' Journal of Historical Geography 42 (2014): 111-29; Kerby A. Miller, Emigrants and Exiles: Ireland and the Irish Exodus to North America (New York; Oxford: Oxford University Press, 1985), 280-344; R. Dudley Edwards, The Great Famine: Studies in Irish History 1845-52 (Dublin, Ireland: Browne, 1956).

${ }^{235}$ For this description of typhus, see Arthur Allen, The Fantastic Laboratory of Dr. Weigl: How Two Brave Scientists Battled Typhus and Sabotaged the Nazis (New York; London: W.W. Norton \& Company, 2014), 18, 21-23.

${ }^{236}$ Leslie A. Clarkson and E. Margaret Crawford, Feast and Famine: Food and Nutrition in Ireland, 1500 1920 (Oxford: Oxford University Press, 2001), 152-54, 158-160.

${ }^{237}$ See M. R. Smallman-Raynor and A.D. Cliff, War Epidemics: An Historical Geography of Infectious Diseases in Military Conflict and Civil Strife, 1850-2000 (New York: Oxford University Press, 2004). 
measures. ${ }^{238}$ The cholera epidemic of 1832 had forced the establishment of Boards of Health and inspection and quarantine stations at major ports of entry and along the St. Lawrence and Great Lakes, but the still "rudimentary system" was quickly overwhelmed by the typhus-stricken migrants. ${ }^{239}$ Kingston was fortunate to have a Board of Health, but despite the exhaustive attempts of sisters and other basic healthcare workers to nurse and save migrants, thousands died before the summer was out, including previously healthy residents who died from contagion. A total of 1,400 Kingston dead, both newly arrived migrants and residents, were buried together in a hastily dug mass grave. ${ }^{240}$

The emigrants arrived at Grosse Île, a quarantine station for the Port of Québec, where they were confined in deficient housing without proper food, water, or clothing. ${ }^{241}$ Disastrously, what had been incipient for many of the immigrants on the "coffin ships" or at Grosse Île, was quickly carried inland. ${ }^{242}$ The quarantine measures were largely ineffective. The majority of the over 50,000 immigrants who intended to settle in Upper Canada (Canada West) traveled by way of the Rideau Canal and the St. Lawrence River, with an estimated 2500 immigrants passing through Kingston each week. ${ }^{243}$ Animosity

\footnotetext{
${ }^{238}$ Vincent J. Cirillo, review of War Epidemics: An Historical Geography of Infectious Diseases in Military Conflict and Civil Strife, 1850-2000 by M. R. Smallman-Raynor and A.D. Cliff, Journal of the History of Medicine and Allied Sciences 61, no. 1 (January 2006): 91, https://muse.jhu.edu/article/191184/pdf.

${ }^{239}$ Errington, "British Migration and British America," 149. Kingston's Board of Health had been established during the 1832 outbreak of cholera. See Geoffrey Bilson, A Darkened House: Cholera in Nineteenth-Century Canada (Toronto: University of Toronto Press, 1980), 14-15, 61, 82-84, 114-15. ${ }^{240}$ Osborne, "The Cemeteries of the Midland District of Upper Canada," 51. See also Mary Ellen Perkins, "The Typhus Epidemic 1847," Discover Your Heritage: A Guide to Provincial Plaques in Ontario (Toronto: Dundurn, 1989), 55. The Ontario historical plaque about the typhus epidemic may be seen at St. Mary's Cemetery in Kingston where the mass grave was moved in 1966.

241 Jaclyn Duffin, History of Medicine: A Scandalously Short Introduction (Toronto: University of Toronto Press, 2010, $2^{\text {nd }}$ edition), 176.

${ }^{242}$ Mark G. McGowan, Death or Canada: The Irish Famine Migration to Toronto, 1847 (Ottawa: Novalis, 2009), 38-40. The phrase “coffin ships” originated from Thomas D'Arcy McGee's 1848 St. Patrick's Day speech to the where he made reference to the ships carrying Irish migrants as "sailing coffins." See Fitzgerald and Lambkin, Migration in Irish History, 172-73.

${ }^{243}$ Statistic of '2500' cited in Alan G. Green, "Immigrants in the City: Kingston as Revealed in the Census Manuscripts of 1871," 317; Osborne and Swainson, 128. Osborne put this number closer to 40,000 in "The Cemeteries of the Midland District of Upper Canada," 51.
} 
towards the immigrants increased as the hardship faced by local Canadians grew.

Municipal authorities struggled to respond adequately to the epidemic and integrate the new arrivals into their society. With a population of roughly 10,000 people, the epidemic had a significant impact on Kingston. ${ }^{244}$ As with the cholera epidemic of 1832 , fear of contagion led to strident opposition and some residents temporarily left Kingston and other affected city centers for what they hoped would be places of greater safety, they hoped, in the countryside. ${ }^{245}$ The typhus epidemic was similar to the cholera outbreak in more ways than one. At mid-century, health authorities had not yet realized that cholera was transmitted through fecal matter in the water supply or via contaminated food, ${ }^{246}$ rather than through impure air, often referred to as "miasma,"247 and there was still an ongoing debate about how exactly typhus was spread. ${ }^{248}$ David Barnes argues that quarantine measures were ineffective in the nineteenth-century because they were "based on a loosely articulated but firmly held conviction that foul or contaminated air could be imported from overseas in vessels and goods, and under certain conditions could spark deadly disease outbreaks." ${ }^{249}$ It would take the 1866 cholera epidemic before Kingston's

\footnotetext{
${ }^{244}$ Nancy McMahon, "Les Religieuses Hospitalières de Saint Joseph, 41-42. See also Jaclyn Duffin, History of Medicine, 174-77.

${ }^{245}$ Keith Duncan, "Irish Famine Immigration and the Social Structure of Canada West," Canadian Review of Sociology 2 (1965): 22; McGowan, Death or Canada, 80.

${ }^{246}$ G.H. Rabbani and W.B. Greenough III, "Food as a Vehicle of Transmission of Cholera," Journal of Diarrhoeal Diseases Research 17, no. 1 (March 1999): 1-9.

${ }^{247}$ In the first half of the nineteenth-century, cholera was thought to spread through foul or impure air, which people referred to as 'miasma.' See Bronwen E. J. Goodyer, “An Assistant Ship Surgeon's Account of Cholera at Sea," Journal of Public Health 30, no. 3 (September 2008): 335. In 1849, Dr. John Snow first raised his theory of cholera transmission through sewer water in the River Thames. See J. Snow, On the Mode of the Communication of Cholera (London: Churchill, 1849).

${ }^{248}$ E. Margaret Crawford, "Typhus in Nineteenth-Century Ireland," chap. 6 in Medicine, Disease and the State in Ireland, 1650-1940, ed. Greta Jones and Elizabeth Malcolm (Cork, Ireland: Cork University Press, 1999).

${ }^{249}$ David S. Barnes, "Cargo, "Infection," and the Logic of Quarantine in the Nineteenth Century," Bulletin of the History of Medicine 88, no. 1 (Spring 2014): 76.
} 
Board of Health and City Council would instate garbage collection and not until the 1880 s for water quality tests to be instituted and water and sewer services expanded. ${ }^{250}$ Judging by the 1847 Journals of the Legislative Assembly, Canadian health authorities and the public were aware typhus was spread through close contact as well as contaminated clothing and bedding but were still unclear if it was also spread by air. ${ }^{251}$ Others took advantage of the situation and preyed on people's fears, as observed in a July advertisement for Dr. Townsend's Sarsaparilla in Québec City's The Morning Chronicle. Billed as "The Most Extraordinary Medicine in the World" for various ailments with accompanying testimonials, the company recommended it as a preventative for 'ship fever': "That this Disease is contagious there now can be no doubt, and is rapidly spreading throughout the country. ... Dr. Townsend's Sarsaparilla will prevent this disease. If the Blood is pure and healthy it is impossible to take this disease or any other." 252 Such claims only created false hope and interfered with the Board of Health's educational aims, which the sisters worked to carry out.

Kingston leaders were soon overwhelmed by the sheer numbers of the sick and dying. The Sisters of the Hôtel-Dieu were part of the joint effort between municipal and public health authorities and a mix of charitable and religious organizations to alleviate the suffering of the typhus victim.$^{253}$ As described in the Religious Hospitallers of Saint

\footnotetext{
${ }^{250}$ Colleen MacNaughton, "Promoting Clean Water in Nineteenth-Century Public Policy: Professors, Preachers, and Polliwogs in Kingston, Ontario," Social History 32, no. 63 (1999): 50-56.

251 “Address to Her Majesty on Immigration," 25 June 1847, Eleventh Year of the Reign of Queen Victoria, JOURNALS OF THE LEGISLATIVE ASSEMBLY OF THE PROVINCE OF CANADA FROM THE 2ND DAY OF JUNE TO THE 28TH DAY OF JULY, 1847 ... IN THE TENTH AND ELEVENTH YEARS OF THE REIGN OF ... QUEEN VICTORIA: BEING THE THIRD SESSION OF THE SECOND PROVINCIAL PARLIAMENT OF CANADA (Montreal: R. Campbell, 1847), 74-75; "Emigrants," July 26 1847, Medical Commissioners to Legislative Assembly, Montreal, 24 July 1847, Eleventh Year of the Reign of Queen Victoria1, Ibid., 98-99.

252 "Dr. Townsend's Sarsaparilla," The Morning Chronicle, July 6, 1847, 1.

${ }^{253}$ For a full description of the Kingston typhus epidemic, see McMahon, "Les Religieuses Hospitalières de Saint Joseph and the Typhus Epidemic," 41-55.
} 
Joseph's Annals, the sisters received special permission from Bishop Phelan to leave the monastic enclosure to assist at the hospital established by the Female Benevolent Society and with those housed in the downtown "fever sheds" on King Street and Emily Street (Fig. 2.4): ${ }^{254}$

While the dread disease was making the rounds in Kingston, Father Macdonell came with a protestant gentleman to ask our Mother if she would kindly come to the aid of the poor emigrants who were sick by the hundreds at the English Hospital. Our Mother accepted the offer with joy, immediately. His Lordship who had been previously consulted sent at once the Obedience to our Mother and all the Sisters. ... In our small wards we had continually some patients with the disease. Often we had to make beds in the wards and the small corridors all on the floor. ... In August having no Sisters to come with me to the English hospital, I took for some days a little orphan girl to accompany me, as I could not go alone. They came for us every morning with a cab and brought us back each evening. I continued thus until the disease abated and from that time until January 1848 there was always more or less several cases. ${ }^{255}$

Gendered expectations specific to nuns and sisters, which "were experienced more rigidly by female religious than by male," ${ }^{256}$ meant Sister Claire Latour could not work alone in public. The typhus epidemic demonstrated just how difficult the requirement of having two sisters together while working or in public could be to fulfil, as well as the added burden it placed on already busy sisters. There was little the sisters could do for the typhus patients but minister to their basic needs.

The issue of mass Irish immigration and the resulting strain on colonial resources and finances was raised repeatedly in parliament, ${ }^{257}$ and the dedication of the sisters did

\footnotetext{
${ }^{254}$ McGowan, Death or Canada, 40. See also Angus, Kingston General Hospital, 24-25.

${ }^{255}$ Sister Latour, "Translation of the Annals of our House of Kingston, 1845 -", Archives of the Religious Hospitallers of St. Joseph, St. Joseph Region, Kingston, 84.1, file 13, typescript, 12-13.

${ }^{256}$ Anne O'Brien, God's Willing Workers: Women and Religion in Australia (Sydney: University of New South Wales Press Ltd., 2005), 199, cited in Megan P. Brock, "Resisting the Catholic Church's Notion of the Nun as Self-Sacrificing Woman," Feminism \& Psychology 20, no. 4 (2010): 475.

${ }^{257}$ Bruce Curtis, "Official Documentary Systems and Colonial Government: From Imperial Sovereignty to Colonial Autonomy in the Canadas, 1841-1867," Journal of Historical Sociology 25, no. 4 (December 2012): 391 .
} 
not go unnoticed. Lord Elgin made special note of the charitable actions of religious in a letter to Lord Grey dated July 13, 1847: "Nothing can exceed the devotion of the nuns and Roman Catholic priests and the conduct of the other clergy and many of the laity of other denominations has been most exemplary. Many lives have been sacrificed in attendance to the sick." ${ }^{258}$ The end of the epidemic was a relief. A head tax was imposed by the colonial government to cover the costs of future migrants, ${ }^{259}$ but for the HôtelDieu Sisters the workload remained constant.

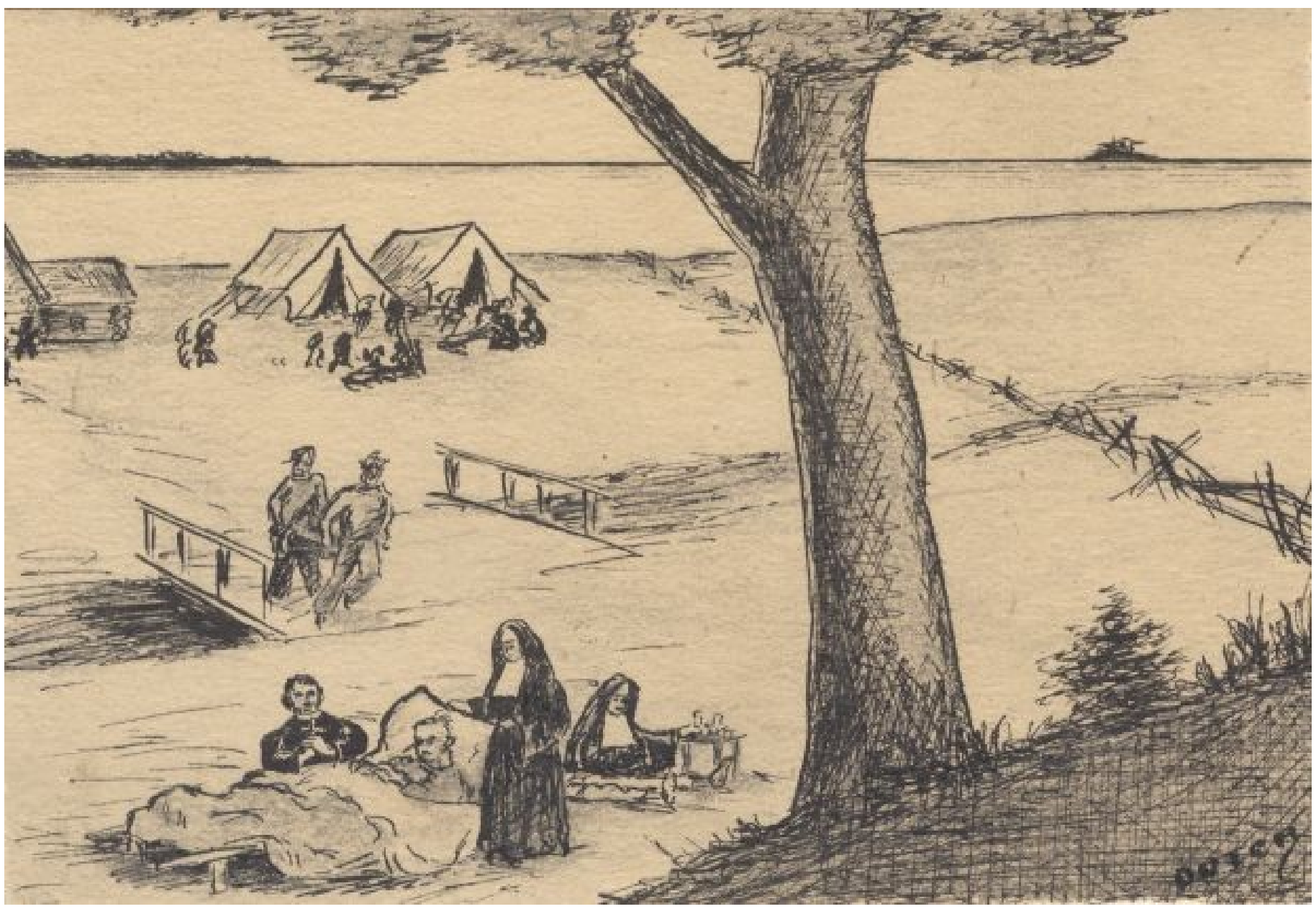

Fig. 2.4 Religious Hospitallers of St. Joseph's caring for typhus victims, Kingston waterfront, 1847. Artist unknown. Archives of the Religious Hospitallers of St. Joseph, St. Joseph Region, Kingston, K-135.

${ }^{258}$ Sir Arthur G. Doughty, ed., The Elgin-Grey Papers, 1846-1852 (Ottawa: J.O. Patenaude, 1937), 59. Also cited in Duncan, "Irish Famine Immigration," 22.

${ }^{259}$ Curtis, "Official Documentary Systems," 391. 


\section{A Sister's Work is Never Done}

By year-end, the Religious Hospitallers of Saint Joseph were not only running their hospital and orphanage, they were also caring for an additional hundred very young and destitute Irish orphans, who had literally arrived on their doorstep on Christmas Eve. According to the annals, the Government subsidized their care and provided the sisters with $\$ 4.00$ per child each month, but in the short-term they scrambled to clothe and feed these children. For a steady source of income to care for their orphans and the poor in their hospital, the nuns hired a male baker and established the Hôtel-Dieu bakery which proved very successful. ${ }^{260}$

Their income and fundraising were not nearly enough to care for the additional Irish typhus orphans. Once the government withdrew their grant, the sisters were forced to "place out" the children into adopted homes. In colonial British North America, caring for abandoned and orphaned children, or fostering impoverished children until their parents could afford to reclaim them, was considered part of the duty of caring for the "general pauper population" rather than a specialized endeavor. ${ }^{261}$ The sisters saw their work differently and ensured that while under their care, even for a brief period as the typhus orphans were, the children received a religious education. ${ }^{262}$ They also hired a governess and two nurses to help care for them. ${ }^{263}$ Not only children bereft of parents

\footnotetext{
${ }^{260}$ RHSJ-SJRA. 84.1-13. Annals of the Hotel Dieu, Kingston, - English and French, 1845-1887, 16-17, 22.

${ }^{261}$ Patricia T. Rooke and R. L. Schnell, "Childhood and Charity in Nineteenth-Century British North America," Social History 15, no. 29 (May 1982): 162.

262 According to historian Veronica Strong-Boag, Catholics considered placing children with nuns in residential care to be just as good, if not better, than in a domestic space. In the nineteenth-century, children were often moved around between friends, family members, or were apprenticed or boarded out. See Finding Families, Finding Ourselves: English Canada Encounters Adoption from the Nineteenth Century to the 1990s (Don Mills, Ont.: Oxford University Press, 2006), 10.

${ }^{263}$ RHSJ-SJRA. 84.1-13. Annals of the Hotel Dieu, Kingston, - English and French, 1845-1887, 16-18.
} 
were in the sisters' care. Generally, the children had been orphaned or abandoned, but desperately poor children were sent there too. A child might stay in the sisters' orphanage for years until a parent's circumstances improved enough for the child to be reclaimed.

When it came to 'placing the children out,' the sisters' main goal was to ensure that the children went to Catholic homes. This was a consistent concern for Protestant and Catholic orphanages who feared 'the other' would use the adoptive process as a means for proselytizing and conversion. ${ }^{264}$ Placing such large numbers of children out for adoption was a heart-wrenching process. By January of 1848, however, the nuns were caring for 130 typhus orphans, this in addition to the orphans already in their care. The annalist wrote of their dilemma in placing out the children:

And as we were strangers we placed none without a ticket or note from the Bishop or his V.G. [Vicar General]. When any one came to ask for a child we used to place them in rows and people took their choice. I assure you it was very painful to witness such a scene, when any of them heard their names mentioned, they knew they were going and began to cry and could not be consoled at seeing themselves separated from their companions and their mistresses, who also did their share of weeping. ${ }^{265}$

When the babies and children arrived, some of whom had been abandoned, the nuns had only two barrels and two boards to serve the children's meals on and, with so little furniture and few dishes, the children had to take turns standing up over the rough table to eat their meals. Cots were sent by generous donors, but the children had shown up in rags and their bundles of clothes, with dirty ticks "full of vermin" and everything scattered on the two floors of the unfinished hospital. It took the four nuns two full weeks to make enough clothes for all the children. Mother Bourbonniere made a salve to heal their

\footnotetext{
${ }^{264}$ E. Wayne Carp, Family Matters: Secrecy and Disclosure in the History of Adoption (Cambridge, Mass.: Harvard University Press, 1998), 12-14.

${ }^{265}$ RHSJ-SJRA. 84.1-13. Annals of the Hotel Dieu, Kingston, - English and French, 1845-1887, 18-19.
} 
wounds, and kind 'Protestant' ladies appeared on a regular basis who gave cloth and money for the orphans and even came on Tuesday afternoons to help the sisters sew clothing for the children. ${ }^{266}$ It is clear the nuns' first and foremost concern was for the welfare of those in their care, rather than the rules of the cloister.

Exploring the history of the City of Kingston, Ontario, it is evident that community minded philanthropic women of some means and Catholic sisters aided the needy, and provided “poor relief” in Kingston, Ontario. ${ }^{267}$ Kingston's wealthy Protestant women banded together to form the Ladies of the Female Benevolent Society and the Widows' and Orphans' Friends Society. Through fundraising and government grants, the ladies opened the city's first public hospital, spearheaded the establishment of Kingston's 'House of Refuge' in 1850, and the Protestant Orphan's Home. ${ }^{268}$ As Dorothy Farr notes in her discussion of Kingston, women worked together to create a society that supported the needy. ${ }^{269}$ Catholic sisters and philanthropic Protestant women had similar goals, underpinned by Christian morality and a firm sense of the importance of respectability and one's place. They were separated by theological rather than ideological differences.

Using hard data to evaluate these women's accomplishments is not always possible. Using nineteenth-century Canadian census records, Heidi MacDonald has

\footnotetext{
266 Ibid.

${ }^{267}$ Patricia Malcolmson, "The Poor in Kingston," 281-297; Dorothy Farr, "Introduction" in Elain M. McKay, Beyond the Silhouette: Fashion and the Women of Historic Kingston (Kingston, Ont.: Agnes Etherington Art Centre, 2007), 15; Montigny, "Families, Institutions, and the State in Late-Nineteenth Century Ontario," 74.

${ }^{268}$ According to Stormie Stewart, although the Kingston's House of Industry received provincial funding, it was run privately. Stewart, "The Elderly Poor in Rural Ontario," 217n; Patricia T. Rooke and R. L. Schnell, "The Rise and Decline of British North American Protestant Orphans' Home as Woman's Domain, 18501930," Atlantis 7, no. 2 (Spring 1982): 23; Brigid Goulem, "Workhouse to Welfare: A Look Back at Kingston's First Social Reform Institute,” The Queen's Journal (25 January 2018), https:/www.queensjournal.ca/story/2018-01-25/features/workhouse-to-welfare.

${ }^{269}$ Farr, "Introduction,"15.
} 
argued that excluding nuns from the census indicates that their labour was not valued.

She asserts that, "In the case of the devaluing of nuns' labour, we can look to bishops and other members of church hierarchy who often did not appreciate the value of nuns' contributions to the Catholic social order." ${ }^{270}$ It is true that sisters were often unpaid or underpaid and excluded from key decision-making processes reserved for the all-male hierarchy. But this should not necessarily be equated with a lack of appreciation of valuable contributions in providing critical social services. Because the 1844 census of Kingston's Catholics did include Sisters St. Agatha, St. Alexander, and St. Edward, teachers of the Congrégation de Notre-Dame who were stationed there that spring of $1844,{ }^{271}$ perhaps Kingston's sisters were left out of official Canadian census data due to poor timing or miscommunication from the collector of the census data rather than as an intentional slight.

Exploring the work experiences of the Religious Hospitallers of Saint Joseph, Congrégation de Notre-Dame and Sisters of Providence of St. Vincent de Paul in nineteenth-century Kingston reaffirms that women religious "inhabited a gendered public space that demanded a prominent presence and a substantial silence." 272 Sisters' professionalism in schools, hospitals, and prisons demonstrated their achievements, and rightly earned them a positive reputation and the respectability that they required to overcome sectarianism.

\footnotetext{
${ }^{270}$ Heidi MacDonald, "Who Counts and Why?," 373.

${ }^{271}$ RC Diocese of Kingston, "Census of the Catholic population of the Mission of Kingston," 11.

${ }^{272}$ Kathleen A. Brosnan, "Public Presence, Public Silence: Nuns, Bishops, and the Gendered Space of Early Chicago" The Catholic Historical Review 90, no. 3 (July 2004): 474.
} 


\section{Chapter 3: Obstacles in Nineteenth-Century Ontario, Real and Imagined}

The sisters who departed for Kingston between 1841 and 1861 anticipated no small measure of difficulties in their new home. Leaving Montréal's supportive French Catholic environment and its well-organized system of charitable institutions was not a comfortable choice. ${ }^{273}$ British Protestants held political power in Canada West, and Kingston's still fledgling community of English-speaking Catholics, mainly Irish, faced severe social and economic disadvantages and a pervasive undercurrent of antiCatholicism. The obstacles the sisters faced were more than they had anticipated or could have predicted. Lack of funds, yes, but also insecure and inadequate housing, insufficient workspace, limited personnel, disease, physical hardship, and ecclesiastical authoritarianism. The sisters feared intolerance, but, as their journals and letters make clear, they were pleasantly surprised by the warm reception they received from Kingston's Anglo-Protestant community. Indeed, each religious congregation had consistently positive interactions with "the Protestants" of Kingston. This chapter will explore the obstacles the sisters confronted, both real and imagined, in their attempt to provide the city with expanded and responsive social services, especially for the most economically vulnerable. Despite the constraints imposed on them by their religious vows, gender, and language, the contributions made by the Sisters of the Congrégation de Notre-Dame, the Religious Hospitallers of St. Joseph, and the Sisters of Providence of St. Vincent de Paul, visibly improved the lives of many.

\footnotetext{
273 See Jean-Marie Fecteau and Eric Vaillancourt, "The Saint Vincent de Paul Society and the Catholic Charitable System in Québec (1846-1921)," in The Churches and Social Order in Nineteenth-and Twentieth- Century Canada, ed. Michael Gauvreau and Ollivier Hubert (Montréal; Ithaca: McGill-Queen's University Press, 2006), 195-224; Roberto Perin, "French-Speaking Canada from 1840," in A Concise History of Christianity in Canada, ed. Terrence Murphy and Roberto Perin (Toronto: Oxford University Press, 1996), 190-259.
} 


\title{
Anti-Catholicism and Anti-Protestantism: Convents, Sisters, Orangemen, Ultramontanes, and Political Implications
}

\author{
Both the Ursulines of Boston, Massachusetts and Montréal's Religious
}

Hospitallers of St. Joseph were subject to virulent anti-Catholic literature in the 1830s. In 1834, the Ursulines' convent in Boston's Charlestown neighbourhood, including chapel and school, was attacked by an angry mob of rioters, desecrated, and burned to the ground. ${ }^{274}$ The riot was prompted, in part, by Rebecca Reed's fabricated stories of abuse and imprisonment, which she accused the sisters of committing during her short time there as a postulant. ${ }^{275}$ Reed published her invented experiences as Six Months in a Convent (1835). ${ }^{276}$ Montréal's Hôtel-Dieu nuns stood at the centre of Maria Monk's sensational and similarly fictitious autobiography, Maria Monk, Awful Disclosures of the Hotel Dieu Nunnery of Montreal (1836). ${ }^{277}$ These were only two of the many “escaped nun narratives" in the gothic horror genre, ${ }^{278}$ and the resulting notoriety from $A w f u l$ Disclosures, described by historian Denis Grube as pornography, ${ }^{279}$ accompanied the

\footnotetext{
${ }^{274}$ Nancy Lusignan Schultz, Fire \& Roses: The Burning of the Charlestown Convent, 1834 (Boston: Northeastern University Press, 2000), 3-9.

${ }^{275}$ Jeanne Hamilton, "The Nunnery as Menace: The Burning of the Charlestown Convent, 1834," U.S. Catholic Historian 14, no. 1 (Winter, 1996): 47; Sandra M. Griffin, Anti-Catholicism and NineteenthCentury Fiction (Cambridge: Cambridge University Press, 2004), 33.

${ }^{276}$ Daniel A. Cohen, "The Respectability of Rebecca Reed: Genteel Womanhood and Sectarian Conflict in Antebellum America," Journal of the Early Republic 16, no. 3 (Autumn, 1996): 419-61; Jenny Franchot, The Antebellum Protestant Encounter with Catholicism (Berkley: University of California Press, 1994), 146.

${ }^{277}$ Franchot, The Antebellum Protestant, 156-62.

${ }^{278}$ Susan M. Griffin, "Women's Evidence in the Escaped Nun's Tale" PMLA 111, no. 1 (January 1996): 96. See also Sandra Frink, "Women, the Family, and the Fate of the Nation in American Anti-Catholic Narratives, 1830-1860," Journal of the History of Sexuality 18, no. 2 (May 2009): 237-64; Kyle Hughes and Donald M. MacRaild, "Anti-Catholicism and Orange Loyalism in Nineteenth-Century Britain," in Loyalism and the Formation of the British World, 1775-1914, ed. Allan Blackstock, Frank O'Gorman (Woodbridge, Suffolk: The Boydell Press, 2014), 66.

${ }^{279}$ Dennis Grube, At the Margins of Victorian Britain: Politics, Immorality, and Britishness in the Nineteenth Century (London: I. B. Tauris, 2013), 299. See also William S. Cossen, "Monk in the Middle: The Awful Disclosures of the Hotel Dieu Nunnery and the Making of Catholic Identity," American Catholic Studies 125, no. 1 (Spring 2014): 28; Ray Allen Billington, "Maria Monk and Her Influence," The Catholic Historical Review Vol. 22, No. 3 (October 1936), 285. Behind 'Maria Monk' were two men, anti-Catholic
} 
Hôtel-Dieu nuns from Montréal to Kingston. ${ }^{280}$

An immediate bestseller, Awful Disclosures was one of the most infamous pieces of anti-Catholic literature published in nineteenth-century America. ${ }^{281}$ The events described were purported to have taken place in the late 1820 s and early 1830 s in the Hôtel-Dieu cloister where Monk claimed to have lived for seven years. ${ }^{282}$ Seizing on the very real fears of many Protestants, the plot of Awful Disclosures was predictable. It pivoted around a young Protestant girl who fell under the sway of seemingly kindly nuns and was converted to Catholicism, enters the convent, confronts lurid sexual licentiousness between supposedly celibate priests and nuns, encountered a mother superior intoxicated by her own power, is held captive behind convent walls, and only narrowly escaped. ${ }^{283}$ Sandra Griffin argues that all anti-Catholic literature shared a common aim: to contrast the domestic ideal of feminine Protestant Victorian mothers who taught their children biblically-based principles, "with the church and priest-centered worship of Catholics. ${ }^{284}$ Its sensationalism drew readers in, and most unfortunate for Canada's Religious Hospitallers of St. Joseph, would "form the touchstone of Protestant suspicions and accusations for the rest of the century." 285

ministers J.J. Slocum and George Bourne, who were believed to have created and written the manuscript and used Monk as a proxy. See Griffin, Anti-Catholicism and Nineteenth-Century Fiction, 33.

${ }^{280}$ Rebecca Sullivan, "A Wayward from the Wilderness: Maria Monk's Awful Disclosures and the Feminization of Lower Canada in the Nineteenth Century," Essays on Canadian Writing 62 (Fall 1997):

201-22.

${ }^{281}$ Maura Jane Farrelly, Anti-Catholicism in America, 1620-1860 (Cambridge: Cambridge University Press, 2018), 156.

282 Philippe Sylvain, “MONK, MARIA," in Dictionary of Canadian Biography, vol. 7, University of Toronto/Université Laval, 2003-, accessed January 10, 2018, http://www.biographi.ca/en/bio/monk_maria_7E.html.

${ }^{283}$ Joseph G. Mannard, "Maternity... of the Spirit: Nuns and Domesticity in Antebellum America," U.S. Catholic Historian 5, no. 3/4 (Summer - Fall 1986): 306-15.

${ }^{284}$ Griffin, Anti-Catholicism and Nineteenth-Century Fiction, 5.

${ }^{285}$ Philip Ingram, "Protestant Patriarchy and the Catholic Priesthood in Nineteenth Century England," Journal of Social History 24, no. 4 (Summer, 1991): 784. 
The bishop and sisters in Kingston, and especially the Hôtel-Dieu nuns, were mindful of the effects of such literature. Awful Disclosures differed from other "escaped nun” texts due to Maria Monk's detailed and libelous descriptions of real people. ${ }^{286}$ Monk specifically named Montréal's Hôtel-Dieu nuns as a group, although names of specific sisters were inaccurate, and she also named Father Patrick Phelan, who would be appointed coadjutor to Bishop Gaulin in Kingston in the 1840s, as well as Montréal's bishop and other diocesan priests. Before his appointment as Bishop, Father Patrick Phelan had ministered to the growing Irish Catholic community in Montréal. ${ }^{287}$ An Irish emigrant himself, Phelan's deep commitment to Montréal's Irish population since his ordination there in 1825 was well-known. He had been prominent in advocating for temperance, and Catholic education, and in caring for victims of the infamous cholera epidemics of 1832 and $1834 .^{288}$ Monk claimed that while in the convent cellar one day, she found a trapdoor with steps leading downwards into the dark, and that:

At first, I could not imagine the use for such a passage; but it afterward occurred to me, that this might open to the subterranean passage to the Seminary, for I never could account for the appearance of many of the priests, who often appeared and disappeared among us, particularly at night, when I knew the gates were closed. They could, as I now saw, come up to the door of the Superior's room at any hour, then up the stairs into our sleeping-room, or where they chose. And often they were in our beds before us. ${ }^{289}$

\footnotetext{
286 See Sullivan, “A Wayward from the Wilderness," 202.

287 J. E. Robert Choquette, "PHELAN, PATRICK," in Dictionary of Canadian Biography, vol. 8, University of Toronto/Université Laval, 2003-, accessed August 4, 2018, http://www.biographi.ca/en/bio/phelan_patrick_8E.html. Sherry Olson and Patricia Thornton, "The Challenge of the Irish Catholic Community in Nineteenth-Century Montreal," Social History 35, no. 70 (2002): 337; Rosalyn Trigger, “Irish Politics on Parade: The Clergy, National Societies, and St. Patrick's Day Processions in Nineteenth-Century Montreal and Toronto," Social History 37, no. 74 (2004): 169, 177, 185; Sherry Olson, "Silver and Hotcakes and Beer: Irish Montreal in the 1840s," Canadian Ethnic Studies 45, no. 1-2, (2013): 186.

${ }^{288}$ Choquette, "PHELAN, PATRICK," Dictionary of Canadian Biography.

${ }^{289}$ Maria Monk, The Awful Disclosures of Maria Monk and the Mysteries of a Convent (Philadelphia: T.R. Peterson, 1836), 93. There were multiple editions of The Awful Disclosures of Maria Monk published, and the excerpts in this thesis are taken from this edition. See also Choquette, "PHELAN, PATRICK," Dictionary of Canadian Biography.
} 
She continued her narrative, accusing Father Patrick Phelan of raping her and plotting to

kill their unborn baby:

Would a child destined to destruction, like the infants I had seen baptized and smothered, be allowed to go through the world unmolested ... Could I suppose that Father Phelan, Priest of the Parish Church of Montreal, would see his own child growing up in the world, and feel willing to run the risk of having the truth exposed? What could I expect, especially from him, but the utmost rancour, and the most determined enmity, against the innocent child and its abused and defenceless mother? ${ }^{290}$

Such suggestions were countered with disbelief, disgust, and derision by Montréal's

newspapers. ${ }^{291}$ Although ultimately discredited in the mainstream American press, ${ }^{292}$

rumors nevertheless persisted. The accusations shadowed the nuns and Phelan throughout

the remainder of their lives, and even had to be addressed at Phelan's funeral in Kingston

in 1857:

The year 1835 (sic) witnessed all that malice could suggest, or that a slandering press could produce, to tarnish the character of that saintly priest, and bring into disrepute the conduct of the inmates of that Charitable Institution, the Hôtel-Dieu ... It is most painful to me to have to call into question the revered name of Father Phelan, as if the least shadow of suspicion or doubt could be attached to his conduct in connection with the prostitute Maria Monk. ${ }^{293}$

Monk's pointed attacks on the sisters reveals what commended women religious to those inside and outside the Catholic Church during the period: their work ethic, cleanliness,

\footnotetext{
${ }^{290}$ Maria Monk, The Awful Disclosures, 151.

${ }^{291}$ Sullivan, "A Wayward from the Wilderness," 205; The Clergyman who served Bishop Phelan' s last Mass, Life of Right Reverend Patrick Phelan, Third Bishop of Kingston: To Which is Added a Synopsis of the Lives of the Two First Bishops of Kingston (Kingston: William Lightfoot, 1862), 10.

292 As one of the American "Protestant gentleman" observed at the time, the people of Montréal were dismissive of Maria Monk: "Such a city of skeptics, in all that pertained to the disclosures of the wronged frail one, was never before seen. Nay, more, so perfectly absurd and ridiculous did the people with one accord consider the whole affair, that they seemed to look upon the denizens of the United States, as laboring under a widely extended monomania!" See William L. Stone, Maria Monk and the Nunnery of Hotel Dieu being an Account of a Visit to the Convents of Montreal, and Refutation of the "Awful Disclosures" (New York: Howe \& Bates, 1836), 10. ${ }^{293}$ Anon., Life of Right Reverend Patrick Phelan, 9, 11.
} 
educational institutions, superior medical care, and acts of charity. Monk wrote disparagingly of the 'Congregational Nunnery' where she supposedly attended school:

There were about fifty girls in the school, and the nuns professed to teach something of reading, writing, arithmetic, and geography. The methods, however, were very imperfect, and little attention was devoted to them... The nuns had no very regular parts assigned them in the management of the schools. They were rather rough and unpolished in their manners, often exclaiming, "C'est un menti," (that's a lie,) and "mon Dieu," (my God,) on the most trivial occasions. Their writing was quite poor, and it was not uncommon for them to put a capital letter in the middle of a word. ${ }^{294}$

Sisters had found social acceptance through their labour, even in uneasy religious and political circumstances, which anti-Catholic literature then attempted to undermine. If they were shown not to be outstanding teachers or nurses with gentle, feminine manners, not to be holy women above reproach who kept exceptionally clean hospitals, classrooms, and convents, then they had no real place in society. The place and respect accorded to Catholic nuns and priests, and the services they provided, varied greatly in different parts of colonial Canada. In Lower Canada and Canada East, Roman Catholic religious were at the core of the available social services and education system, and to many, even its very identity.

Circumstances in Canada West, however, were drastically different. The sisters had good reason to be wary in Kingston. As John Wolffe has argued, the anti-Catholicism in British North America paralleled what was happening in Britain, Ireland, and the United States, and there were incidents of both implicit and explicit anti-Catholicism in the Canadas. ${ }^{295}$ British authorities were historically suspicious of Catholics maintaining a

\footnotetext{
${ }^{294}$ Monk, The Awful Disclosures, 9.

295 John Wolffe, "Anti-Catholicism and the British Empire, 1815-1914," in Empires of Religion, ed. Hilary M. Carey (Basingstoke, England; New York: Palgrave Macmillan, 2008), 44-49; Denis G. Paz, Popular Anti-Catholicism in Mid-Victorian England (Stanford, California: Stanford University Press, 1992), 299;
} 
split allegiance between the monarch and the Pope, ${ }^{296}$ and Catholic men were only granted the right to vote in England in $1829 .{ }^{297}$ J.R. Miller has argued that the antiCatholicism present in the early to mid-nineteenth-century had been introduced by Americans and the British rather than having emerged from settled Canadians. ${ }^{298}$ Donald Akenson, historian of the Irish migration to Canada, has stated that the anti-Catholicism prevalent in Ontario and throughout pre-Confederation Canada was unlike the “systematic discrimination” American Irish Catholics regularly confronted. ${ }^{299}$

Analyzing the English-speaking communities of Catholics in this period of Ontario's history, most were recent Irish immigrants fleeing famine and a depressed economy. Heightened tensions between Catholics and Protestants were predictable, almost an inevitable by-product of widespread fears about the high numbers of Catholic immigrants flooding the country, and the consequences such a large influx of people would have for Canada's economic and social fabric. J.R. Miller has pointed out that antiCatholicism was theological, social, and political. ${ }^{300}$ Moreover, both Pope Pius IX, the last absolute ruler of the Papal States, and his faithful ultramontanes, conservative Catholics who perceived the Church's truth, morals, and values to be under attack,

Grube, At the Margins of Victorian Britain, 84-85. See also E. R. Norman, Anti-Catholicism in Victorian England (New York: Barnes \& Noble, 1968).

${ }^{296}$ Grube, At the Margins of Victorian Britain, 85-86.

${ }^{297}$ Roger Collins, Keepers of the Keys of Heaven: A History of the Papacy (New York: Basic Books, 2009), 443.

${ }^{298}$ J.R. Miller, "Bigotry in the North Atlantic Triangle: Irish, British and American Influences on Canadian Anti-Catholicism, 1850-1900," Studies in Religion/Sciences Religieuses 16, no. 3 (1987): 290-92; "AntiCatholicism in Canada: From the British Conquest to the Great War," in Creed and Culture: The Place of English-Speaking Catholics in Canadian Society, ed. Terrence Murphy and Gerald Stortz (Montreal: McGill-Queen's University Press, 1993), 25-48. See also Stephen Kenny, "A Prejudice that Rarely Utters Its Name: A Historiographical and Historical Reflection upon North American Anti-Catholicism," American Review of Canadian Studies 32, no. 4 (2002): 639-72.

${ }^{299}$ Donald Harman Akenson, Small Differences: Irish Catholics and Irish Protestants, 1815-1922: An International Perspective (Montreal: McGill-Queen's University Press, 1988), 88.

${ }^{300}$ J.R. Miller, "Anti-Catholic Thought in Victorian Canada," Canadian Historical Review 66, 4 (1985):

475. See also J.R. Miller, “Anti-Catholicism in Canada,” 25-48. 
viewed liberal Catholics as being in league with Protestants, unbelievers, and all those opposed to the Church. ${ }^{301}$ Liberal and moderate Catholics for their part generally remained silent on major issues. ${ }^{302}$

Peter Gardella has described in detail how Protestants and Catholics used charges of insanity, sex, and madness to denigrate the other. ${ }^{303}$ Anti-Catholic Protestants, including some of the minority French Protestants in Quebec, viewed the Catholic Church as a bastion of sensuality, superstition, and ignorance, full of congregants manipulated by priests who maintained their seduction through incense, music, pageantry, and the confessional. ${ }^{304}$ Many Roman Catholics, in turn, perceived Protestants as impenitent and immoral, with a misplaced faith in the Bible. ${ }^{305}$ Such deeply-held views sometimes led to political controversy and violence.

\section{Men Fighting Men and the Political Implications of Anti-Catholicism}

More immediately significant and disturbing to Kingston's Catholics was the anti-Catholic Loyal Orange Institution and its cozy political connections. ${ }^{306}$ A secretive

\footnotetext{
${ }^{301}$ Collins, Keepers of the Keys of Heaven, 436-450; Marvin R. O'Connell, "Ultramontanism and Dupanloup: The Compromise of 1865," Church History 53, no. 2 (June 1984): 210. For a study of Pope Pius IX and absolutism, see David I. Kertzer, The Pope Who Would be King: The Exile of Pius IX and the Emergence of Modern Europe (New York: Random House, 2018).

302 John Julius Norwich, Absolute Monarchs: A History of the Papacy (New York: Random House, 2011), 410 .

${ }^{303}$ Peter Gardella, "Possession to Compulsion: Religion, Sex, and Madness in Popular Culture," Social Research 53, no. 2 (Summer 1986): 319.

${ }^{304}$ Richard Lougheed, "Anti-Catholicism Among French Canadian Protestants," Historical Papers: Canadian Society of Church History (1995): 162-166. See also Marie Anne Pagliarini, "The Pure American Woman and the Wicked Catholic Priest: An Analysis of Anti-Catholic Literature in Antebellum America," Religion and American Culture 9, no. 1 (Winter 1999): 97-128.

${ }^{305}$ Michael Gauvreau and Ollivier Hubert, eds., "Beyond Church history: Recent Developments in the History of Religion in Canada," in The Churches and Social Order in Nineteenth-and Twentieth-Century Canada (Montréal; Ithaca: McGill-Queen's University Press, 2006), 3.

${ }^{306}$ Ian Walter Radforth, Royal Spectacle: The 1860 Visit of the Prince of Wales to Canada and the United States (Toronto: University of Toronto Press, 2004), 165; Livermore, "The Orange Order," 245-59.
} 
male society, the Orange Order had its beginning in Ulster Ireland in 1795, formed "as a popular Protestant bulwark against rising Catholic assertiveness in Armagh and other Ulster countries." ${ }^{307}$ According to Canadian historians Cecil Houston and William J. Smyth, the Order identified "the British Crown and Protestant Bible as the two cornerstones of liberty and Protestant Supremacy, and from its inception it was bitterly anti-Catholic in tone." 308 'Orangeism' spread rapidly through Upper Canada and Canada West, and Kingston, the 'Derry of Canada,' was one of its strongholds. ${ }^{309}$ The Siege of Derry, when King James II and his forces laid siege to the city during the JacobiteWilliamite War in Ireland in 1689, was another commemorative flashpoint for the Orange

\footnotetext{
${ }^{307}$ Hughes and MacRaild, "Anti-Catholicism and Orange Loyalism in Nineteenth-Century Britain," 61-62. Roman Catholic men, reputedly impoverished tenants with agrarian grievances, formed a male secret society called the 'Defenders' in 1790s Ulster Ireland, and frequently clashed with the 'Peep o' Day Boys,' the forerunner of the Loyal Orange Institution. See Tom Garvin, "Defenders, Ribbonmen and Others: Underground Political Networks in Pre-Famine Ireland," Past \& Present, no. 96 (August 1982): 133-55; Byron Bland, "Marching and Rising: The Rituals of Small Differences and Great Violence," Journal of Violence, Mimesis, and Culture 4 (Spring 1997): 101-19; Robert McLaughlin, "Irish Nationalism and Orange Unionism in Canada: A Reappraisal," Éire-Ireland 41, no. 3/4 (Fall/Winter 2006): 88. Although the Orange Order, as it is better known, began as an exclusively male society, women also joined and established women's lodges. See D. A. J. MacPherson, Women and the Orange Order: Female Activism, Diaspora and Empire in the British World, 1850-1940 (Manchester: Manchester University Press, 2016). ${ }^{308}$ Cecil J. Houston and William J. Smyth, "Transferred Loyalties: Orangeism in the United States and Ontario," American Review of Canadian Studies 14 (1984): 193. For a discussion of Orangeism and antiCatholicism, see also David A. Roberts, “The Orange Order in Ireland: A Religious Institution?" The British Journal of Sociology 22, no. 3 (September 1971): 269-82, especially 275.

${ }^{309}$ Cecil J. Houston and William J. Smyth, "The Orange Order and the Expansion of the Frontier in Ontario, 1830-1900," Journal of Historical Geography 4, no. 3 (July 1978): 251-64; Brian S. Osborne, The Rock and the Sword: A History of St. Andrew's Presbyterian Church, Kingston, Ontario (Kingston: H. Heine Press at Grass Creek, 2004), 148; Radforth, Royal Spectacle, 165.
} 
Order and impetus of the Order's adopted slogan, 'No Surrender., ${ }^{310}$ Not only Ulster

Irish joined the Orange Order in Canada West, but also Scottish, English, Welsh,

Germans, as well as Loyalist Americans and Canadian Protestants of Irish heritage. ${ }^{311}$

Despite this, by the Spring of 1843, after 18 months in Kingston, the

Congrégation de Notre-Dame reported positively about the state of the city's Protestant-

Catholic relations:

Du 28 avril 1843 : «Nous apprenons des nouvelles de plus en plus favorables du diocèse de Kingston : la foi catholique y fait d'admirables progrès... le nombre d'abjurations dans le cours de la dernière année se monte à 192. Le jour de Pâques, sept nouveaux convertis recevaient dans la cathédrale la sainte communion. On met au tableau d'honneur cette petite ville où la population protestante paraît universellement disposée à embrasser le catholicisme... partout, les préjugés contre les catholiques tombent et s'évanouissent.»> ${ }^{312}$

The peace was not to last, however.

The Orange Order's annual July 12 celebrations to commemorate the Battle of the Boyne, when Protestant King William III of Orange defeated Catholic King James II in

\footnotetext{
${ }^{310}$ Michael E. Geisler, ed., National Symbols, Fractured Identities: Contesting the National Narrative (Middlebury, VT.: Middlebury College Press; Lebanon, NH: University Press of New England, 2005), ix-x; John Childs, The Williamite Wars in Ireland, 1688-1691 (London: Hambledon Continuum, 2007), 1-149; John Gibney, "'Sarsfield Is the Word': The Heroic Afterlife of an Irish Jacobite," New Hibernia Review 15, no. 1 (Spring 2011): 65-66; Brian Walker, "1641, 1689, 1690 and All That: The Unionist Sense of History," The Irish Review, no. 12 (Spring - Summer, 1992): 56-64; Paul Logue and James O'Neill, "Excavations at Bishop's Street Without: 17th Century Conflict Archaeology in Derry City," Journal of Conflict Archaeology 2, no. 1 (2006): 49-75. The Siege of Derry continued to be reenacted in the nineteenth-century by Loyalist Ulster Protestants in plays and commemorated in songs, poems, and books. See John Graham, Ireland Preserved; or the Siege of Londonderry and Battle of Aughrim, with Lyrical Poetry and Biographical Notes by the Rev. John Graham (Dublin: Hardy \& Walker; London: R. Groombridge, 1841); Charlotte Elizabeth, The Siege of Derry, or, Sufferings of the Protestants: A Tale of the Revolution (New York: John S. Taylor \& Co., 1844, $2^{\text {nd }}$ American edition). For a comprehensive history of the Loyalist interpretation and commemoration of the Siege of Derry, see Ian McBride, The Siege of Derry in Ulster Protestant Mythology (Dublin: Four Courts Press, 1997).

${ }^{311}$ McLaughlin, "Irish Nationalism and Orange Unionism in Canada," 86-91; Murray W. Nicolson, "The Irish Experience in Ontario: Rural or Urban?" Urban History Review 14, no. 1 (June 1985): 42-43; ${ }^{312}$ Cited in Soeur Saint-Henriette and Thérèse Lambert, Histoire de la Congrégation de Notre-Dame de Montréal (Montréal: Maison-Mère de la Congrégation de Notre-Dame de Montréal, 1941), 167.
} 
$1690,{ }^{313}$ began with banners, songs, and parades, frequently ended in violent clashes throughout the province, and particularly in Kingston. ${ }^{314}$ When Governor Metcalfe declared that no processions could be held on July 12 of 1843, Kingston's Orangemen held a meeting instead, and all too predictably, encountered angry Irish Repealers. ${ }^{315}$

In 1823, Daniel O’Connell had founded the Catholic Association of Ireland, a political movement for Catholic emancipation backed by the Irish Catholic establishment, and the precursor to O'Connell's Loyal National Repeal Association, which had been established in 1840 to advocate for a repeal to the 1800 Acts of Union between Britain and Ireland. ${ }^{316}$ O'Connell's campaign for Catholic emancipation, although opposed by many Ulster Protestants, led to the Roman Catholic Relief Act of $1829 .{ }^{317}$ The Relief Act had several implications, but chief among them was an end to the penal laws, which allowed for Catholic education and, most importantly to O'Connell, gave him the opportunity to become the Member of Parliament for Country Clare. ${ }^{318}$ The early 1840 s was an especially active period for the Irish Repealers.

On the 'Glorious Twelfth’ of 1843, Kingston's Orangemen and Repealers clashed on the street. A fierce riot broke out. Despite military intervention, sixteen-year old

\footnotetext{
${ }^{313}$ David Cairns, "The Object of Sectarianism: The Material Reality of Sectarianism in Ulster Loyalism," The Journal of the Royal Anthropological Institute 6, no. 3 (September 2000): 440.

314 Jessica Harland-Jacobs, "Maintaining the connexion": Orangeism in the British North Atlantic World, 1795-1844," Atlantic Studies 5, no. 1 (2008): 35.

315 John Mercier McMullen, The History of Canada: From its First Discovery to the Present Time, Vol. 2 (Brockville: McMullen, 1891, $3^{\text {rd }}$ edition), 190. See also Smyth, Toronto, the Belfast of Canada, 23.

${ }^{316}$ Christine Kinealy, Repeal and Revolution: 1848 in Ireland (Manchester: Manchester University Press, 2009), 23-59; Jacqueline R. Hill, "Nationalism and the Catholic Church in the 1840s: Views of Dublin Repealers," Irish Historical Studies 19, no. 76 (September 1975): 371-395; Maureen Slattery, "Irish Radicalism and the Roman Catholic Church in Quebec and Ireland, 1833-1834: O'Callaghan and O’Connell Compared," CCHA, Historical Studies 63 (1997): 32-33.

${ }^{317}$ Suzanne T. Kingon, "Ulster Opposition to Catholic Emancipation, 1828-9," Irish Historical Studies 34, no. 134 (2004): 137-55.

${ }^{318}$ Ultán Gillen, “Ascendency Ireland, 1660-1800," chap. 2 in The Princeton History of Modern Ireland, ed. Richard Bourke and Ian McBride (Princeton: Princeton University Press, 2016), 48-58; Cusack, Life of Daniel O'Connell, 537-78.
} 
Robert Morrison, an innocent bystander, was shot and killed and several others injured. ${ }^{319}$ A group of Orangemen physically intimidated Bishop Phelan, damaged the new stonework of the Roman Catholic Cathedral, and then, after breaking into the watchman's home, poured ash and water on his bed, destroying it. ${ }^{320}$ However, the Congrégation de Notre-Dame's convent and school were not threatened or attacked. Alcohol was acknowledged as having played a role in the violence. Kingston had its own whiskey distillery and an astonishing ninety-eight taverns in $1840 .{ }^{321}$ The Kingston press expressed their outrage towards the Orangemen who they argued had incited the violence. $^{322}$

These physical battles between men of differing Christian denominations should be considered within the broader context of masculinity and a time period when people "rioted to protest social and economic changes which threatened their status in society and their ability to govern their own lives." ${ }^{323}$ In the Canadas and the Maritimes, changes, modifications, and improvements were constantly being made to government institutions and administrative policies in the mid to late-nineteenth-century, including to the

\footnotetext{
${ }^{319}$ McMullen, The History of Canada, 190; John Charles Dent, The Last Forty Years: Canada Since the Union of 1841 (Toronto: George Virtue, 1881), 295; H. Clare Pentland, Labour and Capital in Canada, 1650-1860 (Toronto: J. Lorimer, 1981), 127-28. Some accused the Kingston Repealers of being "Ribbonmen," an unsubstantiated charge, especially as merely being an Irish Repealer and supporter of O'Connell brought censure in Kingston. See James A. Roy, Kingston: The King's Town (Toronto: McClelland \& Stewart, 1952), 217. The Ribbon societies were Irish Catholic secret societies known for their violent clashes with Orangemen, and their support of the Catholic Association and the Repeal Movement. They were strongly denounced by Daniel O'Connell who consistently advocated for peaceful constitutional change. For an understanding of 'Ribbonism,' see Garvin, 'Defenders, Ribbonmen and Others," 133-155; M. R. Beames, "The Ribbon Societies: Lower-Class Nationalism in Pre-Famine Ireland," Past \& Present, no. 97 (November 1982): 128-143; Hughes and MacRaild, "Anti-Catholicism and Orange Loyalism in Nineteenth-Century Britain," 64.

${ }^{320}$ Roy, Kingston, 218-19.

${ }^{321}$ Robert Leslie Jones, History of Agriculture in Ontario, 1613-1880 (Toronto: University of Toronto Press, 1946), 88.

${ }^{322} \mathrm{Ibid}$.

${ }^{323}$ Michael S. Cross, "The Laws Are Like Cobwebs: Popular Resistance to Authority in Mid-Nineteenth Century British North America," Dalhousie Law Journal 8, no. 3 (1984): 104.
} 
cumbersome judicial system. ${ }^{324}$ Aggression and physical confrontation in Canada West was seen as a manly response to an argument, even over theological differences, and commonly occurred in spaces where performances of masculinity were anticipated, such as the tavern or the street. ${ }^{325}$ A shift towards "hard work" and "restraint," representing a new construction of masculinity, would only come in the late nineteenth-century. ${ }^{326}$

Most Catholics and Protestants were embarrassed by the militant fervor displayed by their fellow believers. One writer to Kingston's British Whig described his thoughts on the matter in the following terms: "you are all madman alike." ${ }^{327}$ Lest the Orangemen grow complacent, forgetting the Order's long-term goals of resisting "Papal aggression," and converting Roman Catholics, ${ }^{328}$ Rev. Hilton addressed his Canadian audience on July 12, 1859:

If we wish to win the Romanists to a purer form of religion, let us strive to win them by love, and by prayer, and by the word of God, ... and moreover, the very instant that we begin to use hard measures, or to feel hard and bitter against them personally, that instant we become partakers of their sins ... I must also raise my

\footnotetext{
${ }^{324}$ Paul Romney, "Upper Canada (Ontario): The Administration of Justice, 1784-1850," Manitoba Law Journal 23 (1995): 183-213. As the legal system underwent changes, new positions reflected the improved the judicial system. In 1847, the Canada West provincial government appointed a 'stipendiary magistrate' to Kingston. Usually the role of stipendiary magistrate went to barristers, who "enjoyed a degree of relative autonomy, but remained sensitive to community feeling." See Greg Marquis, "The Contours of Canadian Urban Justice, 1830-1875," Urban History Review 15, no. 3 (February 1987): 271.

${ }^{325}$ Kevin B. Wamsley and Robert S. Kossuth, "Fighting It Out in Nineteenth-Century Upper Canada/Canada West: Masculinities and Physical Challenges in the Tavern," Journal of Sport History 27, no. 3 (Fall 2000): 418-420, 422-424. For a discussion of nineteenth-century physical confrontation as 'manly,' see also John Tosh, A Man's Place: Masculinity in the Middle-Class Home in Victorian England (New Haven: Yale University Press, 1999), 111.

${ }^{326}$ Brenda D. Frink, “'God Give Us Men!': Manliness, the American Protective Association, and Catholicism in San Francisco, 1893-1896," Ex Post Facto: Journal of the History Students at San Francisco State University, 11 (2002): 50.

327 “Kildare's Defence," 9 November 1847, Letter to the Editor, Daily British Whig (Kingston, ON), 10 Nov 1847, 2.

328 Pope Pius IX's 1850 restoration of the papal hierarchy in England and Wales was considered a major act of papal aggression. It should also be noted that outside of Ireland, Canada's Orange Order was the most active in perpetrating anti-Catholic violence. See Donald M. MacRaild, "Transnationalising "Anti-Popery": Militant Protestant Preachers in the Nineteenth-Century Anglo-World," Journal of Religious History 39, no. 2 (June 2015): 227. For an in-depth discussion of "papal aggression," see Walter Ralls, "The Papal Aggression of 1850: A Study in Victorian Anti-Catholicism," Church History 43, no. 2 (June 1974): 24256.
} 
voice against the very unchristian like harangues.... It is quite right that their sins, and erroneous doctrines should be pointed out to you, but is it right, is it Christian-like, to rake up against them year after year, the great wickednesses which they have committed, and pour upon them a torrent of foul language for nearly half an hour at a time'? ${ }^{329}$

He reminded his listeners and readers that Catholics were their brethren, irrespective of differences over the Bible and theological doctrine. He also called on them to be mindful that Orangemen were "too often made the mere tools of some crafty and designing politician." 330 Even John A. Macdonald became a member in 1841 for political reasons. ${ }^{331}$ Both Roman Catholics and Orangemen mobilized, and were mobilized by politicians, with the intention of gaining political influence and power. ${ }^{332}$

The Bishops of Kingston, Bytown (Ottawa), Toronto, Hamilton and London, defended, supported, and championed the rights of the Roman Catholic minority in Anglo-Protestant Canada West, and Kingston's Bishop Alexander Macdonell had been appointed to the Legislative Council of Upper Canada in $1831 .{ }^{333}$ When in a celebration of Empire, young Prince Albert Edward and his guardian, the Duke of Newcastle and

\footnotetext{
${ }^{329}$ Rev. John Hilton, An Address, to the Orangemen of Canada, July 12, 1859 (Port Hope: Guide Job Office, 1859), 9. For reference to Papal aggression, see 10. as the Masonic Lodge and the Oddfellows before entering the political arena to gain votes. See Richard Gwyn, John A.: The Man Who Made Us: The Life and Times of John A. Macdonald, Vol. 1: 1815-1867 (Toronto: Vintage Canada, 2008), 58-59.

332 Dennis Pilon, "The Contested Origins of Canadian Democracy," Studies in Political Economy 98, no. 2 (2017): 111, 114.

${ }^{333}$ Brandon S. Corcoran and Laura J. Smith, "Bishop Macdonell and the Friends of Ireland: Mixing Politics and Religion in Upper Canada," CCHA, Historical Studies 79 (2013): 7-23; Murray W. Nicolson, "Ecclesiastical Metropolitanism and the Evolution of the Catholic Archdiocese of Toronto," Social History 15, no. 29 (May 1982): 129-56; J.A. Macdonell, A Sketch of the Life of the Honourable and Right Reverend Alexander Macdonell: Chaplain of the Glengarry Fencible or British Highland Regiment, First Catholic Bishop of Upper Canada, and a Member of the Legislative Council of the Province (Alexandria: Office of the Glengarrian, 1890), 60. For a history of the religious relations in Upper Canada, with special reference to the Roman Catholic Church and Protestant denominations in or near Kingston, see William Canniff, History of the Settlement of Upper Canada (Ontario): With Special Reference to the Bay Quinte (Toronto: Dudley \& Burns, 1869), 279-308.
} 
Colonial Secretary, came to British North America for two months in $1860,{ }^{334}$ the Orangemen of Kingston planned a raucous reception with orange arches. Although their plans were denounced in several cities, the Orange Order refused to back down. ${ }^{335}$ Bishop Horan cleverly outmaneuvered the Orangemen. Avoiding the Kingston controversy altogether, Horan went ahead to Quebec and gave an address to the Prince of Wales on behalf of the Catholic Bishops, where he pledged Catholic allegiance to the Queen and their future King. ${ }^{336}$ During this trip, the Prince visited the Ursuline Sisters' school, where he and his entourage were allowed a privileged entrance into the convent and addressed by the sisters. Prince Albert Edward was impressed, at least according to reporter Nicholas Woods, by the pretty young pupil of the Ursulines who presented him with flowers. ${ }^{337}$ In the end, the Catholic Church made such a favourable impression on the Prince of Wales that it engendered jealously in the Protestant community.

When Prince Albert Edward arrived on the shores of Lake Ontario, Orangeism was at a fever pitch in Kingston. The Orange Order was illegal in England but not in Canada, and the Prince would not go ashore unless the Orangemen removed their insignia, arches, and banners. ${ }^{338}$ They refused do so, resulting in a twenty-four standoff, and the Prince skipping his visit completely, sailing instead down the St. Lawrence to

\footnotetext{
${ }^{334}$ Charles V. Reed, Royal Tourists, Colonial Subjects and the Making of a British World, 1860-1911 (Manchester: Manchester University Press, 2016), xvii.

${ }^{335}$ Nicholas Augustus Woods, The Prince of Wales in Canada and the United States (London: Bradbury \& Evans, 1861), 166, 169.

${ }^{336}$ Robert Cellem, Visit of His Royal Highness the Prince of Wales to the British North American Provinces and United States in the Year 1860 (Toronto: Henry Roswell, 1861),147-49.

${ }^{337}$ Woods, The Prince of Wales in Canada and the United States, 106-107. See also Cellem, Visit of His Royal Highness, 148, 151.

${ }^{338}$ Cellem, Visit of His Royal Highness, 196-97; Norman, Anti-Catholicism in Victorian England, 21; Louise P. Olsen, "The Orange Order, and Its Influence on Canadian Government," The Historian 9, no. 1 (Fall 1946): 84-86.
} 
Belleville. ${ }^{339}$ John A. Macdonald, worried about the Orange vote, spent an hour trying to convince the guardian Duke to allow the Prince to come ashore, in his attempt to balance out the attention given Catholics and Protestants during the tour. ${ }^{340}$ Much to the shock of the press and other Canadian politicians, Macdonald stayed behind in Kingston to assuage the Orangemen's feelings, leaving the Prince and his entourage to continue without him for two weeks. ${ }^{341}$ Throughout Macdonald's political career he was known for his skillful ability to maintain both the Catholic and Protestant vote. ${ }^{342}$ Prince Albert Edward's visit demonstrated that the Catholic Church had made appreciable inroads in the City of Kingston through its charitable establishments, just as Bishops Gaulin and Bourget had once hoped it would.

\section{Forging Ties: Sisters and "the Protestants" of Kingston}

With its Latin, incense, elaborate clothing worn by clerics, and symbolic rituals, the Catholic Mass has long attracted curiosity. This curiosity, and its stronger cousin suspicion, have long-centered on the confessional and the other rituals embraced by Catholics. For Protestants, who confessed directly to God, the confessional was a private

\footnotetext{
${ }^{339}$ Cellem, Visit of His Royal Highness, 196-97; Due to Kingston's fervent Orangemen who followed the Prince's route, the Prince of Wales did not make it ashore in Belleville either.

${ }^{340}$ Donald Creighton, John A. Macdonald: The Young Politician, The Old Chieftain (University of Toronto Press, 1998, reprint), 302-303. Arthur Bousfield and Garry Toffoli, Royal Tours 1786-2010: Home to Canada (Toronto: Dundurn Press, 2010), 50-52. See also J. K. Johnson and P. B. Waite, "MACDONALD, Sir JOHN ALEXANDER,” in Dictionary of Canadian Biography, vol. 12, University of

Toronto/Université Laval, 2003-, accessed July 27,

2018, http://www.biographi.ca/en/bio/macdonald_john_alexander_12E.html.

${ }^{341}$ Creighton, John A. Macdonald, 303; Ged Martin, John A. Maç̄onald: Canada's First Prime Minister (Toronto: Dundurn Press, 2013), 77.

342 J.R. Miller, “This saving remnant': Macdonald and the Catholic Vote in the 1891 Election, " CCHA, Study Sessions 41 (1974): 33-52. See also Frank H. Underhill, “The Development of National Political Parties in Canada," Canadian Historical Review 16, no. 4 (December 1935): 370-73; Gwyn, John A: The Man Who Made Us, Vol. 1, 200. Although as Ged Martin points out, Macdonald's support in the 1861 election from Kingston's Orangemen was affected by the 1860 debacle. See Martin, John A. Macdonald, 78.
} 
and mysterious space, whose proceedings sealed the penitent's sins upon pain of excommunication, and which smacked of sacrilege. ${ }^{343}$ Catholic religious life similarly nourished confusion, curiosity, and condemnation over the vows of poverty, celibacy, and obedience. ${ }^{344}$ Cloistered monasteries and convents, inaccessible to outsiders, sparked anger, and wild imaginings, ${ }^{345}$ where "the convent was a world of subterranean passages, concealed doors, strange and secretive midnight burial processions, grotesque items of torture and anonymous prisoners in darkened dungeons, the world, in fact, of the gothic novel incarnate. ${ }^{346}$ There were regular demands to be allowed in for inspection tours. ${ }^{347}$ When in September of 1834, the Ursulines of Charlestown were attacked for their status as unattached single women living together under the "unnatural" authority of male clerics, ${ }^{348}$ specifically Bishop Benedict Joseph Fenwick in this instance, the Superior's tart response was reported as following:

The business of my community has, however, been transacted by myself; and though I have, many times, asked his [Fenwick's] opinion on various subjects, no one can thence infer that he or any other gentleman, has exerted control over our

\footnotetext{
${ }^{343}$ Grube, At the Margins of Victorian Britain, 85. See also Timothy Pearson, "In the Eyes of the Children this was a Miracle": Sanctity in Nineteenth-Century Quebec," CCHA, Historical Studies, 70 (2004): 97.

${ }^{344}$ Historically, the celibate state of Roman Catholic men and women religious has been controversial, both celebrated and condemned. See Elisabeth Abbott, A History of Celibacy (Toronto: Harper Collins, 1999), 420-21; McNamara, Sisters in Arms, 1-5, 21, 42-47, 54-56, 73-76, 106, 246-261, 386, 420; Don Swenson, "Religious Differences between Married and Celibate Clergy: Does Celibacy Make a Difference?," Sociology of Religion 59, no. 1 (Spring 1998): 37-43. For an understanding of the history and practice of celibacy from the perspective of a Catholic religious and scholar, see Sandra M. Schneiders, Selling All: Commitment, Consecrated Celibacy, and Community in Catholic Religious Life (New York, N.Y.; Mahwah, N.J.: Paulist Press, 2001). Celibate priests were even the focus of medical studies in the nineteenth-century. See Timothy Verhoeven, "Harmful or Benign? Transnational Medical Networks and the Celibacy of Priests," Journal of Religious History 39, no. 2 (June 2015): 244-60.

345 Susan P. Casteras, "Virgin Vows: The Early Victorian Artists' Portrayal of Nuns and Novices," Victorian Studies 24, no. 2 (Winter 1981): 157-67.

${ }^{346}$ Ingram, "Protestant Patriarchy and the Catholic Priesthood in Nineteenth Century England," 784.

${ }^{347}$ Miriam Elizabeth Burstein, "Protestants, Convents, and Seduction by Matthew 10:37," Victorian Review Volume 37, no. 2 (Fall 2011): 16-20. See also Walter L. Arnstein, Protestant versus Catholic in MidVictorian England: Mr. Newdegate and the Nuns (Columbia: University of Missouri Press, 1982).

348 Daniel A. Cohen, "Miss Reed and the Superiors: The Contradictions of Convent Life in Antebellum America," Journal of Social History 30, no. 1 (Autumn 1996): 151.
} 
institution. Moreover, I think that it would be a difficult matter for any man to control me. ${ }^{349}$

Yet, what many thought "unnatural" or took for secrecy, was in fact a desire for privacy and silence. Colleen Gray argues that the cloister's “ideal purpose was not entirely the guarding of chastity (although this factor cannot be discounted), but the protection of the prayerful way of life, encouraging union with God, and sheltering the religious from agitations and the potentially disruptive spirit of the external world." ${ }^{350}$ For nuns and sisters, such as the three Kingston congregations who spent their lives in the public eye, the cloister was set aside as a contemplative space.

Thus, on April 4 of 1864, when the Kingston public was extended an open invitation to attend a Ceremony of Profession, many seized on what they thought might be their only chance to observe sisters and their unusual rituals up close. Usually vows took place in the sisters' chapel, but for reasons of size, Bishop Horan decided that the Cathedral would be preferable for the two novices of the House of Providence. The Ceremony of Profession was full of symbolically rich ritual and was prescribed by the congregation's ceremonial. The most solemn moment during the Profession Ceremony, as in a wedding, comes when the vows are pronounced. As they observed the ceremony, the public attendees were themselves under close observation. The community's Annalist wrote comments about the day, reflecting on the Protestants in the crowd:

After having pronounced their vows in a tone the most decisive, and which filled all those who gave audience with surprise especially the Protestants who were thronged thither to satiate their vindictive spirit of curiosity, but who, nevertheless comported themselves with decency seeming all the while to be awe-stricken at the solemnity of the proceeding. ${ }^{351}$

\footnotetext{
${ }^{349}$ Mother St. George Moffat, "To the Editor," Boston Recorder, 18 September 1834, cited in Hamilton, "The Nunnery as Menace," 50.

${ }^{350}$ Gray, The Congrégation de Notre-Dame, 19.

351 “Annals of the House of Providence, Kinston: Beginning in the Year 1861," 7.
} 
Unbeknownst to many, sisters spent their lives reading and praying the scriptures, and the amount of scripture in the ceremony must have surprised a few non-Catholics in the pews. ${ }^{352}$ For Protestants, the Bible was a mainstay of family devotional practice. Catholics, on the other hand, were not forbidden to read the scriptures, if they read an ecclesiastical authorized translation of the Bible, such as the Douay-Rheims-Challoner version used by English-speaking Catholics in the United States and British North America. Neither, however, was this practice actively encouraged. ${ }^{353}$

Despite divisions over the Bible and Separate Schools, and outbreaks of violent Orangeism and anti-Catholic rhetoric, on a personal level Kingston's Protestant and Catholic communities amicably assisted one another in providing social services. Sisters received help in all quarters from the Protestant community. Even before the Religious Hospitallers of St. Joseph had left Montréal, Dr. William Hallowell, a Protestant doctor, offered to treat the nuns and their Kingston patients free of charge. ${ }^{354}$ A succession of Protestant doctors came and went and provided their services freely, until Bishop Phelan persuaded a Catholic doctor to come from Cornwall. Together the sisters and Phelan gave him $\$ 120$, but he left after a year. The Protestant ladies of Kingston, including Minister Brunel's wife and daughter, sent clothes and came to assist with the orphaned Irish at the Hotel-Dieu following the typhus outbreak. ${ }^{355}$ Moments of crisis forged close connections between philanthropic Protestant ladies and the sisters, and the wider Protestant

\footnotetext{
352 Cassandra L. Yacovazzi, “Are You Allowed to Read the Bible in a Convent?”: Protestant Perspectives on the Catholic Approach to Scripture in Convent Narratives, 1830-1860," U.S. Catholic Historian 31, no. 3 (Summer 2013): 23-46.

${ }^{353}$ Emil A. Wcela, "What is Catholic about a Catholic Translation of the Bible?," The Catholic Biblical Quarterly, 71 no. 2 (Apr. 2009): 252.

354 Flynn, Built on a Rock, 185.

${ }^{355}$ Hotel-Dieu Annals, 84.13, 18.
} 
community was consistently generous. Theological antipathy did not extend to daily

relations.

\section{Begging Tours}

Kingston's Sisters of Providence did not earn a fixed income or have a wealthy

benefactor, nor did they initially receive government grants for their care of the orphaned, elderly, and visits to Kingston Penitentiary. ${ }^{356}$ Instead, they relied on Bishop Horan and the kindness of multiple donors who gave in small increments. Bishop Bourget had

foreseen their extreme poverty before they had left Montréal. He wrote to Bishop Horan in the summer of 1861 about his, and the sisters', expectations:

They think that, to begin with they should not have any sick or infirm to care for in their new Aisle, that they should go into the homes to seek out the suffering to whom they should bring relief. This, in effect, only brings discomfort and fatigue to the body without any monetary sacrifice. The visitation of the sick who cannot go to the hospital, the distribution of alms which can be placed at their disposal clothing, bread, soup and other provisions, the visitations of the prisons and of the penitentiaries if it is judged appropriate, and other good works which require more footsteps than money could well be the beginning of the establishment which your Excellency wishes to found. ${ }^{357}$

When funds were low, two sisters set out together on a "begging tour," traveling door to door collecting donations. Begging tours were not uncommon and other congregations, even teaching sisters, collected donations in this way too. ${ }^{358}$ The priest invited the sisters

\footnotetext{
${ }^{356}$ Ms. Josephine Perras of Montréal gave the Hôtel-Dieu nuns a large donation that enabled them to begin their Kingston foundation. See Flynn, Built on a Rock, 184. Although the Religious Hospitallers of Saint Joseph did receive payment from hospital patients (those who could afford to pay), they did not have a fixed income and, like the Sisters of Providence, also relied on small donations.

${ }^{357}$ Bishop Ignace Bourget to Bishop E.J. Horan, 30 August 1861, Montreal, 104.2C, "Foundation Letters Collection," ASPSVP.

${ }^{358}$ For example, despite their teaching income, the Benedictine Sisters of Switzerland went on "begging tours" as well. See Susan C. Peterson, "A Widening Horizon Catholic Sisterhoods on the Northern Plains, 1874-1910," Great Plains Quarterly 5 (Spring 1985): 129. When in need, congregations found other creative ways to raise funds as well. See Florence Deacon, "More than Just a Shoe String and a Prayer: How Women Religious Helped Finance the Nineteenth-Century Social Fabric," U.S. Catholic Historian 14, no. 1, Beyond the Walls: Women Religious in American Life (Winter, 1996): 67-89.
} 
into his parish bounds and notified his congregants before their arrival, requesting their generosity. The annalist of the Sisters of Providence wrote:

Great hardship attends these beggings especially in the Fall and Winter Season, when Sisters are obliged to ride over rough roads and corduroy bridges sometimes in a lumber wagon, exposed to the keen north wind, or what is little better, journeying through snow drifts in the bitter cold, getting out of the sleigh at every farm house, sometimes having the monotony relieved by being tipped out in a snow bank. ${ }^{359}$

Canada West's poor roads and bridges were well known among nineteenth-century travelers, who recorded "that the condition of the roads was abominable. The surfaces were bumpy and rutted, muddy or dusty. ... Logs and boards were used to produce "corduroy" or "plank" roads. However, the logs would shift, the boards would split, and both would disappear into the mud." 360 Perhaps more terrifying for the sisters was that the mainly wooden bridges they crossed were "susceptible to disintegration, splintering, and floods. ${ }^{361}$

Sister Mary Anselm and Sister Mary Andrew were invited to collect by Father Patrick Harty from his Kemptville parish in February of 1864. The Sisters of Providence's begging tours were generally successful, even if cold and tiring work in the dead of winter. On this occasion, however, Father Harty's arrangements did not prove entirely helpful:

In one instance their driver was an intemperate man, and he imbibed so freely as to lose his way in the woods. A pleasing prospect on a winter's night! After wandering about, the horses managed to find their way to the cleared country

\footnotetext{
359 Sisters of Providence, Annals, 1863, 5.

360 Andrew F. Burghardt, "Some Economic Constraints on Land Transportation in Upper Canada/Canada West," Urban History Review 18, no. 3 (1990): 232-33.

${ }^{361} \mathrm{Ibid} ., 233$. In order to complete the 'macadamized' road from Kingston to Napanee, a process of paving the road with crushed stoned, the legislature voted to loan the enormous sum of $£ 10,000$ in May of 1839 . See "3d Resolution: $£ 10,000$ to complete Kingston and Napanee Road," Journal of the House of Assembly of Upper Canada: From the Twenty-Seventh Day of February, to the Eleventh of May, (Both Days Inclusive,) In the Second Year of the Reign of Queen Victoria; Being the Fourth Session of the Thirteenth Provincial Parliament (Toronto: James Cleland, 1839), 305.
} 
again. As soon as they came to a farm house the jolly driver went in to get a drink for the night was cold. When pledging a toast to the health and success of the Sisters, who by the way were shivering outside in the sleigh, the people of the house became aware of their being outside. They immediately procured a sober driver, and at eleven o'clock at night they found themselves at Father Harty's half fami shed and worn out by hunger, cold, and vexation. ${ }^{362}$

Even before the arrival of the Sisters of Providence, the Catholics of Kingston had the Hôtel-Dieu orphanage and hospital to support, and the Congrégation de NotreDame's charity students to consider. There was a limit to how much more people could give. As it was, Catholics and non-Catholics were aware of the sisters' vow of poverty and the charitable services they provided free of charge. ${ }^{363}$ In return, they donated generously to the sisters' bazaars, as well as of their time, skills, money, and foodstuffs. The Hôtel-Dieu nuns felt that they were a burden to the Kinston community when a bazaar was held in 1861 and they raised eighteen hundred dollars. The annalist reflected:

...we felt we were abusing the generosity of the citizens who two months previous had been obliged to have a bazaar to satisfy the demands of the Bishop in order to buy a house for the Sisters of Charity for which his Excellency is trying to introduce into the diocese. However, the Catholics are the poorest people of Kingston ( $\mathrm{sic}$ ) population and yet they are remarkable for their generosity; and the Protestants are also very good to us. Perhaps God in His boundless mercy will give them the priceless gift of faith. ${ }^{364}$

With such limitations in mind, begging tours sometimes drew the sisters far afield, even into Canada East and the United States. In September of 1863, Bishop Horan wrote Bishop Bourget relating that the Sisters of Providence had been invited by friends of

\footnotetext{
362 Sisters of Providence, Annals, 1863, 6.

${ }^{363}$ For example, see the Sisters of Charity of the Incarnate Word's frank announcement stressing the need to balance the number of charity and paying hospital patients in nineteenth-century San Francisco, cited in Sioban Nelson, Say Little, Do Much: Nursing, Nuns, and Hospitals in the Nineteenth Century (Philadelphia: University of Pennsylvania Press, 2001), 103-104.

${ }^{364}$ Anon Sister., "Translation of the Annals of our House of Kingston, 1857-1881," 84.1-19, trans. Sister Fern Gillespie, 7.
} 
theirs, "to collect in St. Cuthbert's parish and one or two of the neighbouring parishes."365 He was writing for Bishop Bourget's advice on collecting tours and the suitability of the sisters collecting outside their diocese. Bishop Bourget's responded warmly. The sisters had only left his diocese two years previously, and they still had a strong support and many good friends in his diocese. Bourget provided blanket permission to "make collecting tours in the city as well as in the countryside of the diocese of Montréal; and I will always be ready to give letters of introduction with regard to the pastors of the parishes." ${ }^{366}$ A pastor could hardly refuse if the request was made by the bishop and his explicit consent prompted Bishop Horan's strong support as well. The major drawback to these extensive begging tours on which the sisters and those in their care relied was that it drew at least two sisters away from their primary labour for weeks at a time. ${ }^{367}$

Kington's Sisters of Providence required all the tact and good judgement they could muster when collecting donations. They did not always receive a generous welcome and priests were not always keen to have them, or people to give to them. In January of 1865, the Annalist wrote of her sisters' struggles:

... they proceeded thence to Lindsay where they were received by Rev. J. Farrelly, P.P. who permitted them, as on former occasions to collect in the parish. In spite of all obstructions encountered, they braved on through frost and sleet, receiving jeers and spurns, instead of what they sought - they were even refused lodging by some of their charitable Enthusiasts. Still this kind of treatment alarmed not our devoted Sisters, until they found themselves ushered into the presence of a number of priests who had convened at the Pastor's residence. Their conviviality was limited and, in their jocundity, spared not the feelings of the humble sisters of Charity, ... who though possessing Charity in its plenitude yet think nothing of casting disadvantageous reflections according to the popular mode of expressing it, upon the humble daughters of St. Vincent, upon their

\footnotetext{
${ }^{365}$ Bishop E.J. Horan to Bishop Ignace Bourget, 15 September 1863, Kingston, 104.2C, "Foundation Letters Collection," ASPSVP.

366 Bishop Ignace Bourget to Bishop E.J. Horan, 20 September 1863, Montreal, 104.2C, "Foundation Letters Collection," ASPSVP.

${ }^{367}$ Electa, The Sisters of Providence of St. Vincent de Paul, 51.
} 
ungenteel manner of living by begging through the country. Alas! that there are so few St. Vincents among modern clergy! ... A short week's relaxation at home with their dear Sisters the poor sisters had to pay a visit to Gananoque, having been invited, indifferently thither by Rev. Fr. Walsh P.P. ... The reception was literally cold just what the Sisters anticipated, ere felt it in reality. ${ }^{368}$

In other instances, some were too willing to give the little they had to the sisters. On Ash

Wednesday of 1863, the sisters came upon an impoverished family in Duoro, a town 165

kilometres distant from Kingston. When the sisters entered the home, they saw an Irish

family, the father distributing ashes to his six children. ${ }^{369}$ The reader does not learn his

name, but he had fasted all day and walked a total of 23 miles to Mass and then home

again, where the evening meal awaited him:

A few potatoes, some brown bread and herb tea were the dainties that tempted their appetite. On seeing the Sisters he burst into tears blessing God for the favour of such a visit and calling his children to speak to the Sisters, asked them what they were going to give to the Orphans. In vain the Sisters remonstrated that it was not from such as he, they expected aid, that their custom was to pass no house and they were merely making a friendly call. He persisted in giving alms that he might have a share in the Orphans' prayers. He had not much to give - a bag containing a little flour stood in the corner of the cheerless room and this he divided with the Sisters. ${ }^{370}$

Children in the same circumstances were sometimes given into the sisters' care and, as discussed in Chapter 2, not all 'orphans' were bereft of parents. On another collecting tour in early 1864, the sisters encountered "a poor woman who had nothing to give, took off her apron begging the Sisters not to refuse her the consolation and the honour through

\footnotetext{
${ }^{368}$ Sisters of Providence, Annals, 1865, 9-10.

${ }^{369}$ In the Roman Catholic tradition, the palm leaves received on Palm Sunday, the Sunday preceding Easter, are returned to the Church in the new year, burned, and ground into ash. On Ash Wednesday, the ash is blessed and smeared on recipients' foreheads in the shape of a cross typically with the words from Genesis 3:19: "You are dust, and to dust you will return." For Catholics, Ash Wednesday is a reminder of one's mortality and marks the beginning of Lent, a period of forty days of self-denial and penance. See David Philippart, "Making Ashes," Journal of the Liturgical Conference 15, no. 1 (1998): 41-46; Martin Connell, “Ash Wednesday: Meaning and History," Journal of the Liturgical Conference 15, no. 1 (1998): 7-14.

${ }^{370}$ Sisters of Providence, Annals, Ash Wednesday, 1863, 4.
} 
accepting her small offering." 371 These encounters indicate the esteem with which sisters were held by devout Catholics in nineteenth-century Canada West, as well as the razor thin line between poverty and destitution. Remarkably on that early tour of 'three missions' in 1864, which referred to far flung churches where priests would not live inresidence, but go out to preach, the sisters collected: “...in cash, 128 dollars, twelve quarts of flour, twenty-three bushels of wheat, 55 sacks of oats, six quarts of lard, ten comforters, five flannel sheets, several pounds of wool for making stockings, fifteen pillows stuffed with white down and several other small articles which would take too long to enumerate." 372

\section{Housing, Working Conditions, and Coping with Disease}

The sisters were unfortunate in much of their housing and working conditions. When the Congrégation de Notre-Dame first arrived, their house was not ready. As Bishop Bourget remembered, the sisters "having arrived, they found themselves without a house...they had to find lodging in the upper story of a house which was a wretched saloon. After working hard all day teaching the poorest children, they were obliged to put up with the noises of the neighboring houses at night." 373

Sisters were also challenged by tuberculosis. The scourge of nineteenth-century cities, tuberculosis was often attributed to poverty, damp weather, and dirty living conditions. In reality; it was crowded living conditions, close quarters in school, medical facilities, workplaces, and travel conveyances; and the lack of knowledge of its contagion

\footnotetext{
${ }^{371}$ Sr. Mary of the Blessed Sacrament to Bishop Bourget, House of Providence, Kingston, 20 March 1864, translation, 525.106 , 864-17, "Foundation Letters Collection," ASPSVP.

372 Ibid.

${ }^{373}$ ASPSVP.Bishop Ignace Bourget to Revered Mother Philomène, Superior of the Sisters of Providence of Montréal, 1 September 1861, Montreal, 104.2C, "Foundation Letters Collection."
} 
that spread tuberculosis to the poor and wealthy alike in Kingston. Referred to as 'consumption,' there was no cure for tuberculosis at this point. ${ }^{374}$ The Canadian Medical Association only began to champion "germ theory" for consumption in $1877 .{ }^{375}$ Healthy young sisters died in droves from tuberculosis in the nineteenth-century. Fifteen Loretto Sisters under the age of 30 died in one year in a Kentucky convent. ${ }^{376}$ Kingston's women religious died from tuberculosis in greater numbers than smallpox, typhus, diphtheria, and cholera combined; even during the typhus epidemic of 1847; only one Religious Hospitaller died, and just one sister of "choleric fever" in the following years. In 1866, after the deaths of six healthy young sisters from tuberculosis in quick succession, Dr. Michael Sullivan, who treated the Hôtel-Dieu nuns, declared that their deaths were "caused principally by the dampness of the walls in the convents which is quickly going to ruin." 377 According to the Hôtel-Dieu annals, Kingstonians rushed to their rescue: "This rumour alarmed the citizens of Kingston and the principal ones came one day to our parlour to consult with Mother Superior and have her ask our Bishop's permission to make an appeal to the public for aid in the construction of a new monastery." 378 The Bishop consented, but in a play for control, he refused to relinquish compete control in regards to property.

\section{Ecclesiastical Authoritarianism}

Women religious, made doubly subordinate by their gendered positions in the

\footnotetext{
374 Porter, The Greatest Benefit to Mankind, 401-402.

${ }^{375}$ George Jasper Wherrett, The Miracle of the Empty Beds: A History of Tuberculosis in Canada (Toronto: University of Toronto Press, 1977), 11.

376 Kuhns, The Habit, 119.

${ }^{377}$ Hôtel-Dieu Annals, Kingston, March 1866, 15.

378 Ibid.
} 
nineteenth-century Catholic Church and Canada, were often at the mercy of their bishop's pronouncements. In some instances, sisters had recourse to canon law or common law; otherwise their obedience to the bishop was absolute. Although the sisters' relationships with Kingston's successive bishops between 1841 and 1874 were mainly positive, at times they found themselves fighting against ecclesiastical authoritarianism.

The Sisters of the Congrégation de Notre-Dame were in a unique position compared to the Religious Hospitallers of St. Jospeh and the Sisters of Providence. First, the Notre-Dame sisters were only missioned from their Montréal Motherhouse to Kingston and could therefore be recalled at the will of Mother Superior and her council. Under the authority of Kingston's bishop in his diocese, the sisters had recourse to Bishop Bourget in Montréal and significant leverage if they were dissatisfied, such as terminating their Kingston mission, not available to the other two congregations. The Religious Hospitallers of St. Joseph and the Sisters of Providence, once severed from their original communities, became attached to the Kingston Diocese, and therefore made their obedience to the Kinston's bishop. All three groups had recourse to their Rule, but the Hôtel-Dieu nuns and the Sisters of Providence had to appeal to the Pope if circumstances warranted it, while the Congrégation de Notre-Dame had the authority of their General Superior to simply withdraw and close the Kingston mission. Secondly, Bishop Macdonnell had bequeathed his home to the Congrégation de Notre-Dame in his will. In 1853, Bishop Phelan wrote Bishop Bourget of Montréal to tell him that Bishop Gaulin "still persists in turning out the Congregation Nuns, and says he must get their house next May. But I am sure [that] I will not allow such a thing." ${ }^{379}$ By this time,

\footnotetext{
${ }^{379}$ Bishop Patrick Phelan to Bishop Ignace Bourget, 21 March 1853, Kingston, 104.2C, "Foundation Letters Collection," ASPSVP.
} 
however, Bishop Gaulin's health had deteriorated significantly. Given that he was dealing with mental illness, and previously had invited and warmly welcomed the sisters to Kingston 1841, his comments should be disregarded. Gaulin's infirmity was the reason Bishop Phelan had been made his Coadjutor in 1843. However, when Bishop Phelan stated that he "will not allow such a thing," it is important to note that neither he nor Gaulin were legally in a position to evict the sisters from their own property.

Bishop Bourget made very clear to Mother Philomène the duties and responsibilities of the Sisters of Providence upon their arrival in Kingston, forewarning her in the summer of 1861 that:

Each Sister must accept the Community's decisions with all due respect, as if they were an expression of the will of God, at least that the Bishop, who represents Jesus Christ, proclaims openly only that one must accept such and such a decision as coming from God. In accordance with this principle, one must not doubt that God will watch over you in Kingston. It is, then, the Council's task to put into practice the orders of the community, a revelation of faith which is as consoling as this intimate conviction that God Speaks to them through this community organism. On the other hand, each Sister must see in the choice which the council makes of her, for whatever office, the manifestation of the same holy will of God. Also, she must submit herself to it with a sovereign happiness. ${ }^{380}$

In the same letter, Bourget, having found Mother Philomène's outlined letter to Bishop Horan to be "too pompous", revised it and provided his copy to her for the council and community's approval. Condescendingly, he told her, "Let us try, my daughter, to cover with words which are full of simplicity, the treasures of good dispositions that it please[s] God to give us, in His great mercy, and through His pure charity." ${ }^{381}$ Rather than seeing Mother Philomène's assertiveness for what it was, an attempt to secure the best

\footnotetext{
${ }^{380}$ Bishop Ignace Bourget to Sister Philomène, Superior of the Sisters of Providence of Montréal, 1 September 1861, Montreal, 104.2C, "Foundation Letters Collection," ASPSVP.

${ }^{381}$ Bishop Ignace Bourget to Sister Philomène, Superior of the Sisters of Providence of Montréal, 1 September 1861, Montreal, 104.2C, "Foundation Letters Collection," ASPSVP.
} 
conditions for her sisters in Kingston, Bourget used her gender to deliberately misconstrue her words.

Bishop Horan's tenure is perhaps one of the best examples of a traditional authoritarian cleric. Upon his elevation to bishop, Horan immediately began his attempts to organize the Hôtel-Dieu nuns and the Sisters of Providence in Kingston as he desired and how he thought would best serve his diocese. He even went so far as to consult Pope Pius IX about changing the Religious Hospitallers of St. Joseph's Rule without their knowledge or consent. Horan wanted the nuns removed from the cloister to, as he thought, more effectively serve the community. This was contrary to the nuns' vows and expectations, and had they wanted to enter an apostolic congregation, they would have done so in the first place. Their transnational connections were a source of comfort during this trying time. Their Hôtel-Dieu sisters in France and Montréal both offered them homes, should it come to that. Horan evidently saw the error of his ways and let the matter drop, but not before he had caused much consternation and frustration. ${ }^{382}$

Most dramatically however, Bishop Horan refused to turn over the property deed to the Hôtel-Dieu nuns when at their doctor's advice it was recommended that they rebuild. Catholic men were the most active in Kingston, although citizens from varying denominations and social strata were generous when they heard of the sisters' plight. The funds raised, and a committee of Catholic men, including Dr. Sullivan, was struck to determine the best course of action. The members of the committee decided the best way forward was to take swift action, they "believed that once the building was finished, it could be taken at any time for payment on the Episcopal debts, and since we are not

\footnotetext{
382 RHSJ-SJRA. 84.1-19. Typed Transcript (in English) - Continuation of the Annals of the Hotel Dieu Hospital, Kingston, 8 May 1857, The Annals and Chronicles of St. Joseph Province, 17 May 1858, 3-6.
} 
incorporated, all our property is in the Ecclesiastical Corporation and the gentleman forsee the danger of losing their money. So they concluded among them to visit the Bishop and ask him to give the deeds mentioned above and make us a separate corporation. ${ }^{" 383}$ Despite the grave health concerns, which had been acknowledged by Bishop Horan, the nuns, and their doctor, Horan refused to relinquish the property deeds or allow for their incorporation. The money was held by the committee and no progress was made until 1868.

Although the annals make no mention of the momentous occasion, Bishop Horan eventually relented and the Hotel-Dieu nuns were publicly incorporated by the Ontario Legislative Assembly on 4 March of $1868 .{ }^{384}$ At a time when so many women could not own property, the nuns were declared to be:

... a body Politic, and corporate in Deed, and in name by 'The Sisters of l'HôtelDieu' for the Diocese of Kingston in the Province of Ontario, and by that name, shall have perpetual succession and a common seal, and shall have power from time to time, to alter, renew, or change such common seal at their pleasure, and shall... be able and capable to purchase, acquire, hold, possess, and enjoy, and to have, take, and receive, to them and their successors, to, and for the use and purposes of the said Corporation, any lands, tenements, and hereditaments, and real and immoveable property, and estate, situate, lying, and being within the City of Kingston .... and the same to sell, alienate, mortgage, and dispose of, and to purchase others in their stead. ${ }^{385}$

The Bill goes on to that state that, “...the Mother Superioress and her Council for the time being shall have power and authority to make and establish such rules, orders, and regulations, not being contrary to this Act, nor to the Laws in force in the Province."386

\footnotetext{
${ }^{383}$ Ibid., 16.

384 "An Act to Incorporate the Sisters of l'Hotel-Dieu, for the Diocese of Kingston in the Province of Ontario," (4 March 1868), Bill 58, 1-2, Hotel Dieu Kingston Hospital and Community fonds, 84.5-03.016, RHSJ-SJR Archives.

${ }^{385}$ Ibid., 2.

${ }^{386}$ Ibid.
} 
Spiritually, the Hôtel-Dieu were still under Bishop Horan's authority, but in all other respects, they were now entirely autonomous. The nuns named in the Bill, and responsible for its introduction into the Legislative Assembly, were: Reverend Mother Julia O'Brien, Sisters Jane Leahy, Monica Brady, Mary Dubuc, Mary Elizabeth Norris, Lucy McDougall, and Alice McCaffrey (Fig. 3.1). Finally, in 1869, the monastery's dampness still a detriment to the nuns' health, Dr. Sullivan suggested the nuns hold a lottery and use the funds to build an additional wing. Again, people were remarkably generous. The nuns hired an architect from Ottawa, a builder and carpenter in Kingston, and the new wing of the building was ready to move into on 13 December of 1869 . Bishop Horan was away in Rome, and the blessing and the move went ahead without incident. $^{387}$

During the same period, in 1865, the Loretto Sisters left their convent school in Belleville for Toronto. ${ }^{388}$ Bishop Horan, casting about for a solution, settled on sending the Sisters of Providence as teachers. He applied to the Motherhouse for more sisters, but his request was refused since they had few professed personnel and the elderly, orphaned, and incarcerated already to consider in Montréal. Bishop Horan was unaffected by their decision, "determined, not to be hindered by the lack of co-operation on the part of the Mother House, Montréal, he resolved to send those whom he could spare from Kingston, no matter the consequences." 389 Montréal's Mother Superior and her Council were right, there were no professed sisters to spare. Horan sent professed novice, Sr. Mary Edward to

\footnotetext{
${ }^{387}$ RHSJ-SJRA. 84.1-19. Typed Transcript (in English) - Continuation of the Annals of the Hotel Dieu Hospital, Kingston, The Annals and Chronicles of St. Joseph Province, 1869, 18-19.

${ }^{388}$ Flynn, Built on a Rock, 36.

389 ASPSVP, 407-09-A, General Secretary Fonds, Congregational Annals Series, Annals, 1861-1892,

"House of Providence, Kingston," [typed transcript], 11.
} 
the Belleville School as Officer and Head Mistress of the Select school and the boarders, and Sister Coulton, a non-professed sister, was appointed Mistress of the Separate school, and Sr. Keating was appointed for domestic work. ${ }^{390}$ Miss Meagher, a lay person, taught music. As the numbers of students increased, further personnel changes were made. ${ }^{391}$ Initially, the parents were not pleased by the changes. The Loretto Sisters had an excellent reputation as teachers, and these young women were without experience. However, by year's end the Sisters of Providence had been accepted and made a success of things. Bishop Horan, without consulting the sisters or informing any of the parents, announced out of the blue at the end-of-year concert he was withdrawing the sisters back to Kingston because of the complaints he had heard. This, after the sisters had fitted out the convent and school and received a steady income from the province through the separate school board. ${ }^{392}$ While in Kingston, things were dire by winter of 1865 , when in November the sisters, "were again reduced to the last extreme of Poverty, our stock of provisions and money were exhausted our Creditors clamouring for their payment of their bills, and the Sisters were forced to go out and seek food for the Inmates." ${ }^{393}$ Their poverty stretched into December, as they had to pay off creditors, which "found us again in a sad dilemma by reason of our extreme poverty, neither flour, potatoes nor meat of any kind had we in the house, we and our Poor subsisted for upwards of eight days, on salt fish and corn meal." 394 Ultimately their social network proved invaluable, and food and other gifts were showered on them over the Christmas season.

\footnotetext{
${ }^{390}$ Ibid., 11.

${ }^{391}$ Ibid.

${ }^{392}$ Ibid.

${ }^{393} \mathrm{Ibid}$.

${ }^{394}$ Ibid.
} 
Their existence was often feast or famine, and Bishop Horan's poor planning made only worse by his need for control, exacerbated their difficulties. Things came to a head later in 1866 when the community's Mother Superior and her Council withdrew their original sisters back to Montréal, as was their right, including two of the Irish, English-speaking professed sisters. ${ }^{395}$ In the same year, Horan appointed Sister Mary Edward as the first General Superior of Kingston's Sisters of Providence. ${ }^{396}$ In 1869 , instead of elections, Bishop Horan appointed sisters to their 'offices.' ${ }^{397}$ Circumstances continued in this vein until Horan's death in 1875. Although the sisters had recourse to their Rule and Pope Pius IX in these years, the effort of fighting for their rights had to be weighed against what was most important: service to God and His poor.

${ }^{395}$ Electa, The Sisters of Providence of St. Vincent de Paul, 46-47.

${ }^{396}$ Ibid., 47.

397 "House of Providence, Kingston," [typed transcript], 18-9. 


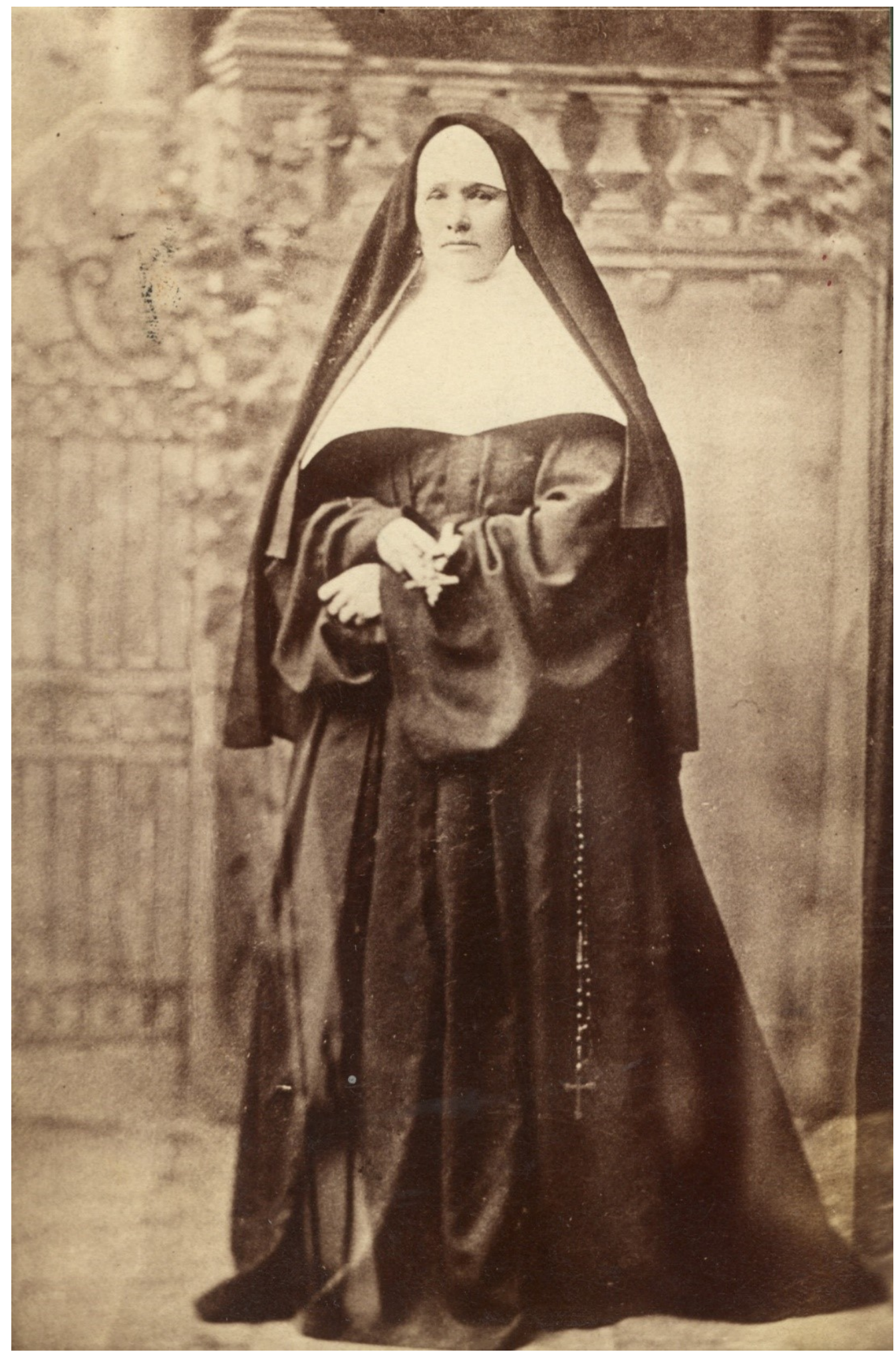

Fig. 3.1 Sister Jane Leahy [before 1887], RHSJ St. Joseph Region Archives, Kingston, K-140. Sister Jane Leahy entered the Novitiate of the Hôtel-Dieu on 14 September of 1852 and was one $f$ the sisters named in Bill 58. This photograph was taken between 1854 and 1887 and is the earliest photograph of a Hôtel-Dieu Kingston Sister held in the Archives. Sister Leahy was elected Superior twice, in 1872 and again in 1884. It is likely the photograph was taken on one of these occasions. 


\section{Conclusion}

Almost from the moment they arrived in mid-nineteenth-century Kingston, the Sisters of the Congrégation de Notre-Dame, the Religious Hospitallers of Saint Joseph, and the Sisters of Providence made their mark on the city's residents, doing so in ways that anticipated the social services of a much later Canada. Long before the Ontario legislature passed the 1893 Act for the Prevention of Cruelty to, and Better Protection of Children, the Hôtel-Dieu nuns and Sisters of Providence fostered or permanently assumed custody of needy, abandoned, and orphaned children. Like today's social workers and public health nurses, the Sisters of Providence visited incarcerated women at Kingston Penitentiary, endeavored to meet the needs of the homeless population, and, several decades before the Victorian Order of Nurses was founded, ${ }^{398}$ nursed the sick in their homes for weeks at a time. The Religious Hospitallers also responded to large-scale public health crises, coordinating medical care with the Ladies of the Female Benevolent Society, a Protestant women's initiative that established Kingston's General Hospital, and Kingston's Board of Public Health. The Congrégation de Notre-Dame championed women's education and ran both a free school and a private school for wealthy girls, the latter subsidizing the former. With the passage of free universal schooling in Ontario, the sisters' schools were integrated into the Separate School system. All three congregations secured partial government funding for each of their establishments and helped lay the groundwork for a broad range of provincial social services.

The success of Kingston's women religious can be attributed to many factors, including their ability to engage successfully with the Kingston community and their

398 Electa, The Sisters of Providence of St. Vincent de Paul, 63-4. 
wider social networks. These networks of generous donors enabled their fundraising efforts and the erection of their physical institutions. Remarkably, during a period of sectarian violence and political upheaval, Kingston's sisters remained respected and resolute. Non-Catholics and Protestants from a range of denominations worked with the Catholic communities of vowed religious to serve Kingston's neediest. The experience of caring for patients during the typhus epidemic of 1847 , and for the orphaned children of the recently arrived Irish migrants, served to bond Protestant and Catholic women. Even when anti-Catholic literature, such as Maria Monk's Awful Disclosures, actively perpetuated prejudice towards the Hôtel-Dieu nuns, they worked unceasingly to better the Kingston community and were rewarded by the support of their neighbours.

Interactions between Catholic women religious and their ecclesiastic superiors were not always cordial, although they knew that they needed the sisters' labour for their diocesan vision to succeed. ${ }^{399}$ This exploration of the manner in which women religious negotiated power structures and gendered imbalances serves to demonstrate that the power of Kingston's bishops was not limitless and their authority not absolute. Sisters and nuns had various means of resistance. Religious had recourse to their Rule, nondiocesan sisters could close missions, and could in extremis be dispensed from their vows. Kingston's women religious established multiple institutions, faced unspeakable risks to their health, and overcame overt anti-Catholicism in carrying out and expanding the city's social services. In doing so, they permanently altered Kingston's spiritual and physical landscape.

\footnotetext{
${ }^{399}$ Nancy Christie and Michael Gauvreau point out that, "Most priests also wanted convents built in their parish for the nuns, who would provide an obedient source of female labour." See Christie and Gauvreau, Christian Churches, 29.
} 


\section{Bibliography}

\section{Primary Sources}

\section{Archival}

\section{Archives of the Archdiocese of Kingston (AAK)}

Correspondence of Bishop Phelan.

\section{Archives of the Congrégation de Notre-Dame, Montréal (ACNDM)}

ACNDM. 310.150.4. "Memorial of the Golden Jubilee, Convent C.N.D., Kingston, Province, Ont., 1841-1891."

ACNDM. 700.010-001. Règlements de la Congrégation de Notre-Dame (Bureau des Mélanges Religieux: Montréal, 1846.

\section{Religious Hospitallers of St. Joseph- St. Joseph Region Archives (RHSJ-SJRA)}

RHSJ-SJRA. Manual of the Religious Hospitallers of Saint Joseph. Mans, France: 1839; Montréal: English trans., Hôtel-Dieu,1896.

RHSJ-SJRA. Ceremonial for the use of the Religious Sisters of St. Joseph after the Rule of Saint Augustin.

RHSJ-SJRA. The Customary and Little Rules of the Religious Hospitallers of the Congregation of St. Joseph. E. Jourdain, La Flèche: 1850; English trans., Hôtel-Dieu, Kingston: 1901.

RHSJ-SJRA. Rules and Constitutions for the Religious Hospitallers of St. Joseph. Kingston: William Bailie, Printer, King Street, 1872.

RHSJ-SJRA. Sister Loretta Gaffney, RHSJ, Provincial/Regional Archivist, and Rodney Carter, Archivist for the St. Joseph Region. Dictionary of Biography of the Religious Hospitallers of Saint Joseph Region: Lives of the Members of the Saint Joseph Region from the Beginnings of the Houses that make up this Region 1845-2014 (updated December 12, 2014).

RHSJ-SJRA. 01.001. "Transcriptions and translations of circular letters (RIP) from houses in France and Montreal (including two written to Mother Bourbonniere) to Kingston.” 1845-1906.

RHSJ-SJRA. 01.004. “Correspondence with Bishop Ignace Bourget.” 1845-1880.

RHSJ-SJRA. 01.008. “Acts of protestation.” 1845. 
RHSJ-SJRA. 01.012. Obediences given by Bishop Ignace Bourget regarding the founding Sisters of Hotel Dieu Kingston and others. 1847-1849.

RHSJ-SJRA. 01.015. Canonical documents regarding the foundation of Hotel Dieu. 1847-1903.

RHSJ-SJRA. 84.1-13. "Typed Transcript of the Annals (in English) - Translation of the Annals of our House of Kingston, 1845 - to -" [translated entries dated 3 February 1891], The Annals and Chronicles of St. Joseph Province.

RHSJ-SJRA. 84.1-13. Typed Transcript of the Annals of the Hotel Dieu, Kingston, English and French, 1845-1887 [English only, 1845-1851], The Annals and Chronicles of St. Joseph Province.

RHSJ-SJRA. 84.1-19. Typed Transcript (in English) - Continuation of the Annals of the Hotel Dieu Hospital, Kingston, May 8, 1857, The Annals and Chronicles of St. Joseph Province.

RHSJ-SJRA. 84.5-03.016. “An Act to Incorporate the Sisters of l'Hotel-Dieu, for the Diocese of Kingston in the Province of Ontario," (4 March 1868), Bill 58, 1-2, Hotel Dieu Kingston Hospital and Community fonds.

\section{Archives of the Sister of Providence of St. Vincent de Paul}

ASPSVP. Daughters of Charity, Servants of the Poor of Montréal, "Rule of the Daughters of Charity," translated into English, 1881.

ASPSVP. 104.2-C. Foundation Letters Collection, 1853-1911.

ASPSVP. 105-C. Ceremonies of Reception and Profession of the Sisters of Charity, 1896.

ASPSVP. 407-409-A. General Secretary Fonds. Congregational Annals Series. Annals, 1861-1892 [typed transcript].

ASPSVP. 408-328. General Treasurer Fonds, Collecting Tours Series, Collections File.

ASPSVP. 410.3.22. Particular Law Collection, Customs and Spiritual Heritage.

\section{Government Correspondence and Documents}

Government of Canada. Censuses of Canada, 1665 to 1871, Statistics of Canada, Volume IV (1876). 
Doughty, Sir Arthur G., ed. The Elgin-Grey Papers, 1846-1852. Ottawa: J.O. Patenaude, printer to the King's Most Excellent Majesty, 1937.

Ryerson, Egerton, ed. "Kingston Educational Items." Journal of Education, Upper Canada 12, no. 3 (Toronto: March 1859): 46.

Ryerson, Egerton; Ontario Department of Education. Ontario Education Report for 1870: with an exposition of the provisions of the School Law Improvement Act of 1871, illustrated by examples of recent school legislation in various countries of Europe and America: being a reprint of the first part of the general report of the Chief Superintendent of Ontario, for 1870. Toronto: Hunter, Rose \& Company, 1871.

Ryerson, Egerton. Special Report on the Separate School Provisions of the School Law of Upper Canada, and the Measures which have been Adopted to Supply the School Sections and Municipalities with School Text Books, Apparatus and Libraries. Toronto: John Lovell, 1858. . "The Story of My Life": Being Reminiscences of Sixty Years' Public Service in Canada, edited by John George Hodgins. Toronto: William Briggs, 1883.

. Report on a System of Public Elementary Instruction for Upper

Canada. Montreal: Lovell and Gibson, 1847.

Ryerson, Egerton, et al. Copies of Correspondence between the Chief Superintendent of Schools for Upper Canada, and Other Persons, on the Subject of Separate Schools (being a continuation of the return laid before the House, and printed on the 17th September 1852). Toronto: Lovell \& Gibson, 1855.

. Correspondence between the Roman Catholic bishop of Toronto and the chief superintendent of schools, on the subject of separate common schools in Upper Canada: with an appendix, containing the provisions of the law and the general regulations regarding religious instruction in our common schools, the regulations of the commissioners of national education in Ireland: also, a consideration of the question of religious instruction in connection with our system of public instruction, from the chief superintendent's annual report for 1851. Toronto: T.H. Bentley, 1853.

. Law of Separate Schools in Upper Canada, by the Roman Catholic

Bishops and the Chief Superintendent of schools: Being the First Part of the Correspondence. Toronto: Lovell \& Gibson, 1855.

Province of Canada, Legislative Assembly. Journals of the Legislative Assembly of the Province of Canada.

Parliament of Lower Canada. The Provincial Statues of Lower Canada. Anno Regni Secundo [1832]: ... Being the Second Session of the Fourteenth Provincial Parliament of Lower Canada [Québec: J.C. Fisher \& W. Kemble, 1832). 
Parliament of Upper Canada. Statues of His Majesty's Province of Upper Canada, Passed in the First Session of the Thirteenth Provincial Parliament of Upper Canada (Toronto: G. Tiffany, 1837).

\section{Newspapers and Magazines}

Boston Recorder

Daily British Whig

Kingston Whig-Standard

The Morning Chronicle

New York Times

The Maple Leaf: A Juvenile Monthly Magazine

The Tablet: A Weekly Newspaper and Review

\section{Books, Magazine Articles, Gazetteers, Pamphlets, and Statistics}

Anon. Reflections on the Terms of Peace. London: Printed for G. Kearsly, 1763.

Canniff, William. History of the Settlement of Upper Canada (Ontario): With Special Reference to the Bay Quinte. Toronto: Dudley \& Burns, 1869.

Cellem, Robert. Visit of His Royal Highness the Prince of Wales to the British North American Provinces and United States in the Year 1860. Toronto: Henry Roswell, 1861.

The Clergyman who served Bishop Phelan's last Mass. Life of Right Reverend Patrick Phelan, Third Bishop of Kingston: To Which is Added a Synopsis of the Lives of the Two First Bishops of Kingston. Kingston: William Lightfoot, 1862.

Colmer, Joseph G. "Some Canadian Railway and Commercial Statistics." Journal of the Royal Statistical Society 51, no. 1 (March 1888): 74-112.

Dickens, Charles. American Notes for General Circulation. New York: J. Winchester, 1842.

Drew, Benjamin. The Refugee: A North-side View of Slavery. Boston: John P. Jewett and Company, 1856.

Elizabeth, Charlotte. The Siege of Derry, or, Sufferings of the Protestants: A Tale of the Revolution. New York: John S. Taylor \& Co., 1844, $2^{\text {nd }}$ American edition. 
Graham, John. Ireland Preserved; or the Siege of Londonderry and Battle of Aughrim, with Lyrical Poetry and Biographical Notes by the Rev. John Graham. Dublin: Hardy \& Walker; London: R. Groombridge, 1841.

Hilton, Rev. John. An Address, to the Orangemen of Canada, July 12, 1859. Port Hope: Guide Job Office, 1859.

"The Hon. Francis Hincks, Prime Minister of Canada," The Illustrated Magazine of Art 3, no. 17 (1854): 351-52.

Howe, S.G. The Refugees of Slavery in Canada West: Report to the Freedmen's Inquiry Commission. Boston: Wright \& Potter, Printers, 1864; New York: Arno Press, New York Times, 1969.

Monk, Maria. The Awful Disclosures of Maria Monk and the Mysteries of a Convent. Philadelphia: T.R. Peterson, 1836.

Morin, Marie. The Annales of Hotel Dieu of Montreal, 1659-1725: Simple and True History of the Establishment of the Religious Hospitallers of Saint Joseph on the Island of Montreal Called at Present Ville Marie in Canada from the Year 1659. Trans. Sr. Sheila Boase, RHSJ, from the critical edition of Ghislaine Legendre. Montréal: Les Éditions Carte blanche, 2010.

Roman Catholic Diocese of Kingston. "Census of the Catholic population of the Mission of Kingston, Canada, taken in the months of May and June of the year 1844 by His Lordship the Right Rev'd Bishop Phelan and the Rev'd Patrick Dollard." Transcribed by Margaret M. Cohoe. Kingston, Ontario: Kingston Branch, Ontario Genealogical Society, 1979.

Shadd, Mary E. A Plea for Emigration, or, Notes of Canada West, edited by Richard Almonte. 1852, reprint; Toronto: Mercury Press, 1998.

Smith, William H. Smith's Canadian Gazetteer: Comprising Statistical and General Information respecting all parts of the Upper Province, or Canada West... with a map of the Upper Province. Toronto: H. \& W. Rowswell, 1846.

Snow, J. On the Mode of the Communication of Cholera. London: Churchill, 1849.

Stone, William L. Maria Monk and the Nunnery of Hotel Dieu being an Account of a Visit to the Convents of Montreal, and Refutation of the "Awful Disclosures." New York: Howe \& Bates, 1836.

Woods, Nicholas Augustus. The Prince of Wales in Canada and the United States. London: Bradbury \& Evans, 1861. 


\section{$\underline{\text { Secondary Sources }}$}

Abbott, Elizabeth. A History of Celibacy. Toronto: HarperCollins, 1999. . A History of Marriage. Toronto: Penguin Canada, 2010.

Adams, Howard. "Roots of Separatism." History of Education Quarterly 8, no. 1 (Spring, 1968): 35-43.

Adams, Nick. "Iroquois Settlement at Fort Frontenac in the Seventeenth and Early Eighteenth Centuries" Ontario Archaeology no. 46 (1986): 5-20.

Akenson, Donald Harman. The Irish in Ontario: A Study in Rural History. Montreal: McGill-Queen's University Press, 1999. 2nd ed.

. Small Differences: Irish Catholics and Irish Protestants, 1815-1922: An International Perspective. Montreal: McGill-Queen's University Press, 1988.

Anbinder, Tyler. "Moving beyond 'Rags to Riches': New York's Irish Famine Immigrants and Their Surprising Savings Accounts." The Journal of American History 99, no. 3 (December 2012): 741-70.

Angus, Margaret. Kingston General Hospital: A Social and Institutional History. Kingston; Montreal: McGill-Queens University Press, 1973. . The Old Stones of Kingston: Its Buildings Before 1867. Toronto: University of Toronto Press, 1966.

Arnstein, Walter L. Protestant versus Catholic in Mid-Victorian England: Mr. Newdegate and the Nuns. Columbia: University of Missouri Press, 1982.

Arnulf, Isabelle, Agnès Brion, Michel Pottier, and Jean-Louis Golmard. "Ring the Bell for Matins: Circadian Adaptation to Split Sleep by Cloistered Monks and Nuns." Chronobiology International 28, no. 10 (2011): 930-941.

Asaka, Ikuko. "Our Brethren in the West Indies": Self-Emancipated People in Canada and the Antebellum Politics of Diaspora and Empire." The Journal of African American History 97, no. 3 (Summer 2012): 219-39.

Axelrod, Paul. The Promise of Schooling: Education in Canada, 1800-1914. Toronto: University of Toronto Press, 1997. 
Baehre, Rainer. "Pauper Immigration to Upper Canada in the 1830s," Social History 14, no. 28 (November 1981): 339-67. no. 1 (1981): 57-80.

Bohaker, Heidi. "Anishinaabe Toodaims: Contexts for Politics, Kinship, and Identity in the Eastern Great Lakes." In Gathering Places: Aboriginal and Fur Trade Histories, edited by Carolyn Podruchny and Laura Peers, 93-118. Vancouver; Toronto: UBC Press, 2010.

Bousfield, Arthur, and Toffoli, Garry. Royal Tours 1786-2010: Home to Canada. Toronto: Dundurn Press, 2010.

Baines, Carol T. “The Professions and an Ethic of Care." In Women's Caring: Feminist Perspectives on Social Welfare, edited by Carol T. Baines, Patricia M. Evans and Sheila M. Neysmith, 36-72. Toronto: McClelland \& Stewart, 1991.

Barker, Adam J. "The Contemporary Reality of Canadian Imperialism, Settler Colonialism and the Hybrid Colonial State." The American Indian Quarterly 33, no. 3 (Summer 2009): 325-51.

Barnes, David S. "Cargo, "Infection," and the Logic of Quarantine in the Nineteenth Century." Bulletin of the History of Medicine 88, no. 1 (Spring 2014): 75-101.

Baskerville, Peter. A Silent Revolution? Gender and Wealth in English Canada, 18601930 (Montreal and Kingston: McGill-Queen's University Press, 2008.

Bauer, Nancy. "Vultum Dei Quaerere: New Norms for Nuns." The Jurist: Studies in Church Law and Ministry 76, no. 2 (2016): 379-414.

Beal, John P., James A. Coriden, and Thomas J. Green, eds. New Commentary on the Code of Canon Law. Mahwah, N.J.: Paulist Press, 2000.

Beames, M. R. "The Ribbon Societies: Lower-Class Nationalism in Pre-Famine Ireland." Past \& Present, no. 97 (November 1982): 128-143.

Begnal, C.N.D, Sister Calista. "Sisters of the Congregation of Notre Dame Nineteenth Century Kingston.” CCHA, Study Sessions 40 (1973): 27-33.

Betts, George M. "Municipal Government and Politics, 1800-1850.” In To Preserve \& Defend: Essays on Kingston in the Nineteenth Century, edited by Gerald Tulchinsky, 223-44. Montreal: McGill-Queen's University Press, 1976.

Billington, Ray Allen. "Maria Monk and Her Influence.” The Catholic Historical 
Review 22, no. 3 (October 1936): 283-96.

Bilson, Geoffrey. A Darkened House: Cholera in Nineteenth-Century Canada. Toronto: University of Toronto Press, 1980.

Bireley, Robert. The Refashioning of Catholicism, 1475 to 1700: A Reassessment of the Counter Reformation. Washington, D.C.: Catholic University of America Press, 1999.

Bladen, M. L. "Construction of Railways in Canada to the Year 1885." Contributions to Canadian Economics, 5 (1932): 43-60.

Bland, Byron. "Marching and Rising: The Rituals of Small Differences and Great Violence." Journal of Violence, Mimesis, and Culture 4 (Spring 1997): 101-19.

Bothwell, Robert. A Short History of Ontario. Edmonton: Hurtig Publishers Ltd., 1986.

Bourinot, John G. Canada under British Rule, 1760-1900. Cambridge: University Press, 1900.

Bradbury, Bettina. "The Home as Workplace." In Labouring Lives: Work and Workers in Nineteenth-Century Ontario, edited by Paul Craven, 412-78. Toronto: University of Toronto Press, 1995.

. «Mourir chrétiennement : La vie et la mort dans les établissements catholiques pour personnes âgées à Montréal au XIXe siècle.» Revue d'histoire de l'Amérique française 46, no. 1 (1992): 143-175, doi:10.7202/305051ar.

.Wife to Widow: Lives, Laws, and Politics in Nineteenth-Century Montreal. Vancouver: UBC Press, 2011.

Brock, Megan P. "Resisting the Catholic Church's Notion of the Nun as Self-Sacrificing Woman." Feminism \& Psychology 20, no. 4 (2010): 473-90.

Brosnan, Kathleen A. "Public Presence, Public Silence: Nuns, Bishops, and the Gendered Space of Early Chicago." The Catholic Historical Review 90, no. 3 (July 2004): 473-96.

Bujaki, Merridee L. "Visualizing the Rideau Canal through Early Budget Estimates, 1823-1824." Accounting History 20, no.1 (February 2015): 43-62.

Bullen, John. "Hidden Workers: Child Labour and the Family Economy in Late Nineteenth-Century Urban Ontario." Labour/Le Travail 18 (Fall 1986): 163-187.

Bumstead, J.M. "The Consolidation of British North America, 1783-1860." In 
Canada and the British Empire, edited by Philip Buckner, 43-65. Oxford; New York: Oxford University Press, 2008. . The Peoples of Canada: A Pre-Confederation History. Oxford; New York: Oxford University Press, 2010, $3^{\text {rd }}$ edition.

Burghardt, Andrew F. "Some Economic Constraints on Land Transportation in Upper Canada/Canada West." Urban History Review 18, no. 3 (1990): 232-36.

Burns, Gene. "The Politics of Ideology: The Papal Struggle with Liberalism." American Journal of Sociology 95, no. 5 (March 1990): 1123-52. . The Frontiers of Catholicism: The Politics of Ideology in a Liberal World. Berkeley: University of California Press, 1992.

Burns, Kathryn. Colonial Habits: Convents and the Spiritual Economy of Cuzco, Peru. Durham, NC: Duke University Press, 1999.

Burstein, Miriam Elizabeth. "Protestants, Convents, and Seduction by Matthew 10:37." Victorian Review Volume 37, no. 2 (Fall 2011): 16-20.

Butler-Jones, David. "A Reflection on Public Health in Canada: Applying Lessons Learned for the Next Century of Public Health Practitioners." Canadian Journal of Public Health 100, no. 3 (May/June 2009): 165-66.

Byrne, Patricia. Review of The Dévotes: Women and Church in Seventeenth-Century France, by Elizabeth Rapley. Social History 27, no. 54 (1994): 476-78.

Cairns, David. "The Object of Sectarianism: The Material Reality of Sectarianism in Ulster Loyalism." The Journal of the Royal Anthropological Institute 6, no. 3 (September 2000): 437-52.

Calloway, Colin G. The Scratch of a Pen: 1763 and the Transformation of North America. Oxford, England; New York: Oxford University Press, 2006.

Cameron, Elspeth. "The Historical Background." Chap. 1 in Multiculturalism and Immigration in Canada: An Introductory Reader, ed. Elspeth Cameron. Toronto: Canadian Scholars' Press, Inc., 2004.

Campbell, Stanislaus, F.S.C. From Breviary to Liturgy of the Hours: The Structural Reform of the Roman Office, 1964-1971. Collegeville, Minn.: Liturgical Press, 1995.

Campey, Lucille H. "Fast Sailing and Copper-Bottomed": Aberdeen Sailing Ships and the Emigrant Scots They Carried to Canada, 1774-1855. Toronto: National Heritage Books, 2002. 
. An Unstoppable Force: The Scottish Exodus to Canada. Toronto:

National Heritage Books, 2008.

Careless, J.M.S. "Some Aspects of Urbanization in Nineteenth-Century Ontario." In Aspects of Nineteenth-Century Ontario: Essays Presented to James J. Talman, edited by F.H. Armstrong, H.A. Stevenson, and J.D. Wilson, 65-79. Toronto: University of Toronto Press, 1974.

Carney, Robert. “Aboriginal Residential Schools Before Confederation: The Early Experience.” CCHA, Historical Studies 61 (1995): 13-40.

Carp, E. Wayne. Family Matters: Secrecy and Disclosure in the History of Adoption. Cambridge, Mass.: Harvard University Press, 1998.

Carr, Thomas. "Writing the Convent in New France: The Colonialist Rhetoric of Canadian Nuns." Quebec Studies 47 (Spring/Summer 2009): 3-23.

Carrigan, D. Owen. Crime and Punishment in Canada: A History. Toronto: McClelland \& Stewart, 1991.

Carstairs, Catherine, and Nancy Janovicek, eds. Feminist History in Canada: New Essays on Women, Gender, Work, and Nation. Vancouver: University of British Columbia Press, 2013.

Carter, Rodney G.S. “"Agreeably surprised and more than pleased”: The Religious Hospitallers of St. Joseph, the Hotel Dieu Hospital, and Regiopolis College." Historic Kingston 58 (2010): 21-40.

Casteras, Susan P. "Virgin Vows: The Early Victorian Artists' Portrayal of Nuns and Novices." Victorian Studies 24, No. 2 (Winter 1981): 157-67.

Chadwick, Owen. The Popes and European Revolution. Oxford: Oxford University Press, 1980.

Chambers, Clarke A. "Women in the Creation of the Profession of Social Work." Social Service Review 60, no. 1 (March 1986): 1-33.

Chaplin, Millicent Mary. Drawing on the Land: The New World Travel Diaries and Watercolours of Millicent Mary Chaplin, 1838-1842, edited by Jim Burant. Manotick, Ontario: Penumbra Press, 2004.

Chaussé, Gilles, and Lucien Lemieux. "LARTIGUE, JEAN-JACQUES.” In Dictionary of Canadian Biography, Vol. 7. Toronto; Québec: University of Toronto/Université Laval, 2003-, http://www.biographi.ca/en/bio/lartigue_jean_jacques_7E.html.

Childs, John. The Williamite Wars in Ireland, 1688-1691. London: Hambledon 
Continuum, 2007.

Choquette, J. E. Robert. "PHELAN, PATRICK," in Dictionary of Canadian Biography, vol. 8, University of Toronto/Université Laval, 2003, http://www.biographi.ca/en/bio/phelan_patrick_8E.html.

Christie, Nancy. “"The Plague of Servants': Female Household Labour and the Making of Classes in Upper Canada." In Transatlantic Subjects: Ideas, Institutions, and Social Experience in Post-Revolutionary British North America, edited by Nancy Christie, 83-132. Montreal: McGill-Queen's University Press, 2008. . “Proper Government and Discipline': Family, Religion, and Masculine Authority in Nineteenth-Century Canada." In What is Masculinity?: Historical Dynamics from Antiquity to the Contemporary World, edited by John H. Arnold and Sean Brady, 389-412. New York: Palgrave Macmillan, 2011.

Christie, Nancy, and Michael Gauvreau. Christian Churches and their Peoples, 18401965: A Social History of Religion in Canada. Toronto: University of Toronto Press, 2010.

Chupungco, Anscar J. OSB, Handbook for Liturgical Studies, Volume V: Liturgical Time and Space. Collegeville, Minn.: Liturgical Press, 2000.

Cimichella, André-M. Émilie Tavernier Gamelin: The Great Lady of Montréal, Foundress of the Sisters of Providence. Outremont, Québec: Les Éditions Carte Blanche, 2002.

Clarkson, Leslie A., and E. Margaret Crawford. Feast and Famine: Food and Nutrition in Ireland, 1500-1920. Oxford: Oxford University Press, 2001.

Cleare, Caitriona. Nuns in Nineteenth-Century Ireland. Washington, D.C.: Gill., 1987.

Clubine, Christopher. "Motherhood and Public Schooling in Victorian Toronto." In Schooling in Transition: Readings in Canadian History of Education, edited by Sara Z. Burke and Patrice Milewski, 115-126. Toronto: University of Toronto Press, 2012.

Coates, Colin M. "French Canadians' Ambivalence to the British Empire." In Canada and the British Empire, edited by Philip Buckner, 181-99. Oxford; New York: Oxford University Press, 2008.

Coburn, Carol. "An Overview of the Historiography of Women Religious: A Twenty-five Year Retrospective.” U.S. Catholic Historian (Winter 2004): 1-26.

Coburn, Carol K. and Martha Smith. Spirited Lives: How Nuns Shaped Catholic Culture 
and American Life, 1836-1920. Chapel Hill, North Carolina: University of North Carolina Press, 1999.

Codignola, Luca. "Competing Networks: Roman Catholic Ecclesiastics in French North America, 1610-58." Canadian Historical Review 80, no. 4 (December 1999): $539-85$.

Cohen, Daniel A. "Miss Reed and the Superiors: The Contradictions of Convent Life in Antebellum America.” Journal of Social History 30, no. 1 (Autumn 1996): 14984.

"The Respectability of Rebecca Reed: Genteel Womanhood and Sectarian Conflict in Antebellum America." Journal of the Early Republic 16, no. 3 (Autumn, 1996): 419-61.

Cohen, Marjorie Griffin. Women's Work, Markets, and Economic Development in Nineteenth-Century Ontario. Toronto: University of Toronto Press, 1988.

Collins, Roger. Keepers of the Keys of Heaven: A History of the Papacy. New York: Basic Books, 2009.

Connell, Martin. "Ash Wednesday: Meaning and History." Journal of the Liturgical Conference 15, no. 1 (1998): 7-14.

Corcoran, Brandon S., and Laura J. Smith. "Bishop Macdonell and the Friends of Ireland: Mixing Politics and Religion in Upper Canada." CCHA, Historical Studies 79 (2013): 7-23

Cossen, William S. "Monk in the Middle: The Awful Disclosures of the Hotel Dieu Nunnery and the Making of Catholic Identity." American Catholic Studies 125, no. 1 (Spring 2014): 25-45.

Coughlin, John J. Canon Law: A Comparative Study with Anglo-American Legal Theory. Oxford; New York: Oxford University Press, 2011.

Coulthard, Glen S. "Subjects of Empire: Indigenous Peoples and the 'Politics of Recognition' in Canada." Contemporary Political Theory 6, no. 4 (November 2007): 437-60.

Crawford, E. Margaret. "Typhus in Nineteenth-Century Ireland.” Chap. 6 in Medicine, Disease and the State in Ireland, 1650-1940, edited by Greta Jones and Elizabeth Malcolm. Cork, Ireland: Cork University Press, 1999.

Creighton, Donald. John A. Macdonald: The Young Politician, The Old Chieftain. University of Toronto Press, 1998, reprint.

Cross, Michael S. "The Laws Are Like Cobwebs: Popular Resistance to Authority in 
Mid-Nineteenth Century British North America." Dalhousie Law Journal 8, no. 3 (1984): 103-23.

Crowley, John E. “"Taken on the Spot': The Visual Appropriation of New France for the Global British Landscape." The Canadian Historical Review 86, no. 1 (March 2005): 1-28.

Crowley, John, William J. Smyth, and Michael Murphy, eds.; Helen Bradley, GIS consultant; Tomás Kelly, editorial assistant. Atlas of the Great Irish Famine, 1845-52. New York: New York University Press, 2012.

Cunningham, Lawrence S. An Introduction to Catholicism. Cambridge: Cambridge University Press, 2009.

Curtis, Bruce. "Class Culture and Administration: Educational Inspection in Canada West." In Colonial Leviathan: State Formation in Mid-Nineteenth-Century Canada, edited by Allan Greer and Ian Radforth, 103-33. Toronto: University of Toronto Press, 1992.

. "Monitorial Schooling, "Common Christianity," and Politics: A Transatlantic Controversy." In Transatlantic Subjects: Ideas, Institutions, and Social Experience in Post-Revolutionary British North America, edited by Nancy Christie, 251-79. Montreal: McGill-Queen's University Press, 2008.

. "Official Documentary Systems and Colonial Government: From

Imperial Sovereignty to Colonial Autonomy in the Canadas, 1841-1867." Journal of Historical Sociology 10, no. 4 (December 1997): 389-417.

. "Pastoral Power, Sovereignty and Class: Church, Tithe and Simony in Quebec." Critical Research on Religion 5, no. 2 (2017): 151-169.

. The Politics of Population: State Formation, Statistics, and the Census of Canada, 1840-1875. Toronto: University of Toronto Press, 2001.

. Ruling by Schooling Quebec: Conquest to Liberal Governmentality - A Historical Sociology. Toronto: University of Toronto Press, 2012.

. "State of the Nation or Community of Spirit? Schooling for Civic and Ethnic-Religious Nationalism in Insurrectionary Canada." History of Education Quarterly 43, No. 3 (Autumn 2003): 325-49.

. "Textual Economies and the Presentation of Statistical Material: Charts, Tables and Texts in 19th Century Public Education." Scientia Canadensis 29, no. 1 (2006): 3-28.

Curtis, Sarah. Civilizing Habits: Women Missionaries and the Revival of French Empire. 
Oxford; New York: Oxford University Press, 2010.

Cusack, M.F. Life of Daniel O'Connell, The Liberator: His Times--Political, Social and Religious. New York; Montreal: D. \& J. Sadlier, 1872.

D'avray, David L. "Stages of Papal Law." Journal of the British Academy 5 (2017): 37 59.

Danylewycz, Marta. Taking the Veil: An Alternative to Marriage, Motherhood, and Spinsterhood in Quebec, 1840-1920, edited by Paul-Andre Linteau, Alison Prentice, and William Westfall. Toronto: McClelland \& Stewart, 1987.

Danylewcyz, Marta, and Alison Prentice. "Teachers' Work: Changing Patterns and Perceptions in the Emerging School Systems of Nineteenth- and Early TwentiethCentury Central Canada." Labour/Le Travail 17 (Spring 1986): 59-80.

Danylewycz, Marta, Beth Light, and Alison Prentice. "The Evolution of the Sexual Division of Labour in Teaching: A Nineteenth-Century Ontario and Quebec Case Study." Social History 16, no. 31 (May 1983): 81-109.

Daveluy, Marie-Claire. "MANCE, JEANNE.” In Dictionary of Canadian Biography, Vol. 1 (Toronto; Québec: University of Toronto/Université Laval, 2003), http://www.biographi.ca/en/bio/mance_jeanne_1E.html.

De Sales, Francis. Introduction to the Devout Life. Translated and edited by Allan Ross. Mineola, New York: Dover Publications, 2009.

Deacon, Florence. "More than Just a Shoe String and a Prayer: How Women Religious Helped Finance the Nineteenth-Century Social Fabric." U.S. Catholic Historian 14, no. 1, Beyond the Walls: Women Religious in American Life (Winter, 1996): $67-89$.

Dear, Michael J., and Jennifer R. Wolch. Landscapes of Despair: From Deinstitutionalization to Homelessness. Princeton: Princeton University Press, 1987.

Dent, John Charles. The Last Forty Years: Canada Since the Union of 1841. Toronto: George Virtue, 1881.

Deroy-Pineau, Francoise. Jeanne Mance: From Langres to Montreal, the Passion for Caring. Translated by Sr. Sheila Boase, RHSJ. Kingston: Religious Hospitallers of St. Joseph, n.d.

Derry, Margaret. "Patterns of Gendered Labour and the Development of Ontario Agriculture." In Ontario Since Confederation: A Reader, edited by Edgar-André Montigny and Lori Chambers, 3-15. Toronto: University of Toronto Press, 2000.

Désilets, Andrée. "HUOT, MARIE-FRANÇOISE, Sainte-Gertrude." In Dictionary of 
Canadian Biography, vol. 7. (Toronto; Québec: University of Toronto/Université Laval, 2003, http://www.biographi.ca/en/bio/huot_marie_francoise_7E.html.

DesRoches, Cheryl. "Everyone in Their Place: The Formation of Institutional Care for the Elderly in Nineteenth-Century Ontario." Journal of the Canadian Historical Association 15, 1 (2004): 49-70.

Dinan, Susan E. and Debra Meyers, eds. Women and Religion in Old Worlds and New. New York; London: Routledge, 2001.

Donovan, Patrick. "Irish Famine Orphans in Canada." In The Canadian Encyclopedia. Toronto: Historica Canada, 1985-, http://www.thecanadianencyclopedia.ca/en/article/irish-famine-orphans-incanada/.

Duffin, Jaclyn. History of Medicine: A Scandalously Short Introduction. Toronto: University of Toronto Press, 2010, $2^{\text {nd }}$ edition.

Duncan, Keith. "Irish Famine Immigration and the Social Structure of Canada West." Canadian Review of Sociology 2 (1965): 19-40.

Ebaugh, Helen Rose. "Patriarchal Bargains and Latent Avenues of Social Mobility: Nuns in the Roman Catholic Church." Gender and Society 7, no. 3 (September 1993): 400-14.

Elbourne, Elizabeth. "Family Politics and Mohawk Diplomacy: The Brant Family in Imperial Context." Journal of Colonialism and Colonial History 6, no. 3 (Winter 2005): 10.1353/cch.2006.0004.

Electa, Sister Mary. The Sisters of Providence of St. Vincent de Paul. Montreal: Palm Publishers, 1961.

Errington, Elizabeth Jane. "British Migration and British America, 1783-1867." In Canada and the British Empire, edited by Philip Buckner, 140-59. Oxford; New York: Oxford University Press, 2008.

. The Lion, the Eagle, and Upper Canada: A Developing

Colonial Ideology. Montreal; Kingston: McGill-Queen's University Press, 1987.

. Wives and Mothers, Schoolmistresses and Scullery Maids: Working

Women in Upper Canada, 1790-1840. Montreal; Kingston: McGill-Queen's University Press, 1995.

. Women and their Work in Upper Canada (Ottawa: Canadian Historical Association, 2006. 
Evangelisti, Silvia. Nuns: A History of Convent Life, 1450-1700. Oxford: Oxford University Press, 2007; 2013.

Ewens, Mary. "The Leadership of Nuns in Immigrant Catholicism." In The American Catholic Religious Life, ed. Joseph White, 26-62. New York: Garland Press, 1988.

Farrelly, Maura Jane. Anti-Catholicism in America, 1620-1860. Cambridge: Cambridge University Press, 2018.

Farr, Dorothy. "Introduction." In Elain M. McKay, Beyond the Silhouette: Fashion and the Women of Historic Kingston. Kingston, Ont.: Agnes Etherington Art Centre, 2007.

Fay, Terence J. "The Jesuits and the Catholic University of Canada at Kingston." CCHA Historical Studies 58 (1991): 57-77. . A History of Canadian Catholics: Gallicanism, Romanism, and Canadianism. Montreal: McGill-Queen's University Press, 2002.

Fecteau, Jean-Marie, and Eric Vaillancourt. "The Saint Vincent de Paul Society and the Catholic Charitable System in Québec (1846-1921).” In The Churches and Social Order in Nineteenth-and Twentieth-Century Canada, edited by Michael Gauvreau and Ollivier Hubert, 195-224. Montréal; Ithaca: McGill-Queen's University Press, 2006.

Fenge, Terry, and Jim Aldridge, eds. Keeping Promises: The Royal Proclamation of 1763, Aboriginal Rights, and Treaties in Canada. Montréal; Kingston: McGillQueen's University Press, 2015.

Ferry, Darren. Uniting in Measures of Common Good: The Construction of Liberal Identities in Central Canada, 1830-1900. Montreal; Ithaca: McGill-Queen's University Press, 2008.

Fialka, John J. Sisters: Catholic Nuns and the Making of America. New York: St. Martin's Press, 2003.

Fiedler, Maureen, and Linda Rabben, eds. Rome Has Spoken: A Guide to Forgotten Papal Statements and How They Have Changed Through the Centuries. New York: Crossroad, 1998.

Field, Anne M. ed. The Monastic Hours: Directory for the Celebration of the Work of God and Directive Norms for the Monastic Liturgy of the Hours. Collegeville, Minn.: Liturgical Press, 2000, $2^{\text {nd }}$ edition.

Finkel, Alvin. Social Policy and Practice in Canada: A History. Waterloo, Ont.: Wilfrid 
Laurier University Press, 2006.

Fitzgerald, Maureen. Habits of Compassion: Irish-Catholic Nuns and the Origins of New York's Welfare System, 1830-1920. Urbana, Ill.: University of Illinois Press, 2006.

Fitzgerald, Patrick, and Brian Lambkin. Migration in Irish History, 1607-2007. New York: Palgrave Macmillan, 2008.

Flynn, Louis J. At School in Kingston, 1850-1973: The Story of Catholic Education in Kingston and District. Kingston, Ontario: Frontenac, Lennox and Addington County Roman Catholic School Board, 1973.

. Built on a Rock: The Story of the Roman Catholic Church in Kingston 1826-1976. Kingston: Roman Catholic Archdiocese of Kingston, 1976.

Foley, Mary Anne. "La vie voyagère for Women: Moving beyond Cloister in Seventeenth-Century New France." CCHA, Historical Studies, 63 (1997): 15-28.

. "We Want No Prison Among Us': The Struggle for Ecclesiastical Recognition in Seventeenth-Century New France," U.S. Catholic Historian 14, no. 1, Beyond the Walls: Women Religious in American Life (Winter 1996): 118.

Frager, Ruth A. Discounted Labour: Women Workers in Canada, 1870-1939. Toronto: University of Toronto Press, 2005.

Franchot, Jenny. The Antebellum Protestant Encounter with Catholicism. Berkley: University of California Press, 1994.

French, Goldwin S. "Egerton Ryerson and the Methodist Model for Upper Canada." In Historical Essays on Upper Canada: New Perspectives, edited by J.K. Johnson and Bruce G. Wilson, 537-53. Ottawa: Carleton University Press, 1989.

Frink, Brenda D. “'God Give Us Men!': Manliness, the American Protective Association, and Catholicism in San Francisco, 1893-1896." Ex Post Facto: Journal of the History Students at San Francisco State University, 11 (2002): 49-64.

Frink, Sandra. "Women, the Family, and the Fate of the Nation in American AntiCatholic Narratives, 1830-1860." Journal of the History of Sexuality 18, no. 2 (May 2009): 237-64.

Frost, Karolyn Smardz, and Veta Smith Tucker, eds. A Fluid Frontier: Slavery, Resistance, and the Underground Railroad in the Detroit River Borderland. Detroit: Wayne State University Press, 2016.

Gaffield, Chad. "Children, Schooling, and Family Reproduction in Nineteenth-Century Ontario." The Canadian Historical Review 72, no. 2 (1991): 157-191. 
. Language, Schooling, and Cultural Conflict: The Origins of the FrenchLanguage Controversy in Ontario. Kingston, Ont.: McGill-Queen's University Press, 1987.

Garcia, Robert W. "The Pivot of Defence of Upper Canada: An Overview of the Structural History of Fort Henry." Ontario Archaeology no. 76, (2003): 54-63. "“This period of desperate enterprise': British Efforts to Secure Kingston from Rebellion in the Winter of 1837-1838," Ontario History 101, no. 2 (Autumn 2009): 142-63.

Gardella, Peter. "Possession to Compulsion: Religion, Sex, and Madness in Popular Culture." Social Research 53, no. 2 (Summer 1986): 311- 26.

Garvin, Tom. "Defenders, Ribbonmen and Others: Underground Political Networks in Pre-Famine Ireland.” Past \& Present, no. 96 (August 1982): 133-55.

Gauvreau, Michael, and Ollivier Hubert, eds. The Churches and Social Order in Nineteenth-and Twentieth-Century Canada. Montréal; Ithaca: McGill-Queen's University Press, 2006.

Geisler, Michael E., ed. National Symbols, Fractured Identities: Contesting the National Narrative. Middlebury, VT.: Middlebury College Press; Lebanon, NH: University Press of New England, 2005.

Gibney, John. "Sarsfield Is the Word': The Heroic Afterlife of an Irish Jacobite." New Hibernia Review 15, no. 1 (Spring 2011): 64-80.

Gidney, R. D. "RYERSON, EGERTON.” In Dictionary of Canadian Biography, Vol. 11. Toronto; Québec: University of Toronto/Université Laval, 2003-, http://www.biographi.ca/en/bio/ryerson_egerton_11E.html.

Gillen, Ultán. “Ascendency Ireland, 1660-1800.” Chap. 2 in The Princeton History of Modern Ireland, edited by Richard Bourke and Ian McBride. Princeton: Princeton University Press, 2016.

Goodyer, Bronwen E. J. “An Assistant Ship Surgeon's Account of Cholera at Sea.” Journal of Public Health 30, no. 3 (September 2008): 332-38.

Graham, George P. "The Powers of Bishops in Recent Documents [notes]," Jurist 28, no. 4 (1968): 425-48.

Gray, Colleen. The Congrégation de Notre-Dame, Superiors, and the Paradox of Power, 1693-1796. Montreal: McGill-Queen's University Press, 2007.

Graymont, Barbara. “KOÑWATSITSIAIÉÑNI (Mary Brant).” In Dictionary of 
Canadian Biography, vol. 4. Toronto; Québec: University of Toronto/Université Laval, 2003-, http://www.biographi.ca/en/bio/konwatsitsiaienni_4E.html.

Green, Alan G. "Immigrants in the City: Kingston as Revealed in the Census Manuscripts of 1871." In To Preserve \& Defend: Essays on Kingston in the Nineteenth Century, edited by Gerald Tulchinsky, 311-30. Montreal: McGill-Queen's University Press, 1976.

Green, Gretchen. "Molly Brant, Catherine Brant, and Their Daughters: A Study in Cultural Acculturation." Ontario History 81, no. 3 (1989): 235-50.

Greer, Allan. The Patriots and the People: The Rebellion of 1837 in Rural Lower Canada. Toronto: University of Toronto Press, 1993.

. The People of New France. Toronto; Buffalo: University of Toronto Press, 1997.

Griffin, C.J. "The Great Famine in Colonial Context: Public Reaction and Responses in Britain before the 'Black '47.'”' Journal of Historical Geography 42 (2014): 11129.

Griffin, Sandra M. Anti-Catholicism and Nineteenth-Century Fiction. Cambridge: Cambridge University Press, 2004.

. "Women's Evidence in the Escaped Nun's Tale." PMLA 111, no. 1 (January 1996): 93-107.

Grube, Dennis. At the Margins of Victorian Britain: Politics, Immorality, and Britishness in the Nineteenth Century. London: I. B. Tauris, 2013.

Guillet, Edwin. The Pioneer Farmer and Backwoodsman, Vol. 2. Toronto: University of Toronto Press, 1970.

Gwyn, Richard. John A.: The Man Who Made Us: The Life and Times of John A. Macdonald, Vol. 1: 1815-1867. Toronto: Vintage Canada, 2008.

Hamilton, Jeanne. "The Nunnery as Menace: The Burning of the Charlestown Convent, 1834,” U.S. Catholic Historian 14, no. 1 (Winter, 1996): 35-65.

Hardill, Kathy. "From the Grey Nuns to the Streets: A Critical History of Outreach Nursing in Canada." Public Health Nursing 24, 1 (2007): 91-97.

Harland-Jacobs, Jessica. "Maintaining the connexion": Orangeism in the British North Atlantic World, 1795-1844." Atlantic Studies 5, no. 1 (2008): 27-49.

Harper, Marjory. "Rhetoric and Reality: British Migration to Canada, 1867-1967.” In 
Canada and the British Empire, edited by Philip Buckner, 160-80. Oxford; New York: Oxford University Press, 2008.

Hedican, Edward J. The First Nations of Ontario: Social and Historical Transitions. Toronto: Canadian Scholars, 2017.

Hendrick, George, and Willene Hendrick. Black Refugees in Canada: Accounts of Escape During the Era of Slavery. Jefferson, N.C.: McFarland \& Co., 2010.

Heron, Craig. "Factory Work." In Labouring Lives: Work and Workers in NineteenthCentury Ontario, edited by Paul Craven, 479-594. Toronto: University of Toronto Press, 1995.

Hill, Jacqueline R. "Nationalism and the Catholic Church in the 1840s: Views of Dublin Repealers." Irish Historical Studies 19, no. 76 (September 1975): 371-395.

Hodgins, John George. The Legislation and History of Separate Schools in Upper Canada: From 1841, Until the Close of the Reverend Doctor Ryerson's Administration of the Education Department of Ontario in 1876: Including Various Private Papers and Documents on the Subject. Toronto: William Briggs, 1897.

Holland, Joe. Modern Catholic Social Teaching: The Popes Confront the Industrial Age, 1740-1958. New York, N.Y.; Mahwah, N.J.: Paulist Press, 2003.

Holosko, Michael, and Donald R. Leslie. "Is Social Work a Profession? The Canadian Response." Research on Social Work Practice 11, no. 2 (March 2001): 201-9.

Houston, Cecil J., and William J. Smyth. "The Orange Order and the Expansion of the Frontier in Ontario, 1830-1900." Journal of Historical Geography 4, no. 3 (July 1978): 251-64.

."Transferred Loyalties: Orangeism in the United States and Ontario.” American Review of Canadian Studies 14 (1984): 193-211.

Hubert, Ollivier. "Ritual Performance and Parish Sociability: French-Canadian Catholic Families at Mass from the Seventeenth to the Nineteenth Century." In Households of Faith: Family, Gender and Community in Canada, 1760-1969, edited by Nancy Christie, 37-76. Montréal, Que.: McGill-Queen's University Press, 2002.

Hudson, J. Blaine. Encyclopedia of the Underground Railroad. Jefferson, N.C.: McFarland \& Co., 2006.

Huels, John M. "Categories of Dispensable and Indispensable Laws." Studia Canonica 39, 1/2 (2005): 41-73.

Hughes, Kyle and Donald M. MacRaild. "Anti-Catholicism and Orange Loyalism in 
Nineteenth-Century Britain." In Loyalism and the Formation of the British World, 1775-1914, edited by Allan Blackstock, Frank O'Gorman, 61-79. Woodbridge, Suffolk: The Boydell Press, 2014.

Iacovetta, Franca. "The Irish in Nineteenth Century Canada: Class, Culture, and Conflict." In A Nation of Immigrants: Women, Workers, and Communities in Canadian History, 1840s-1960s, edited by Franca Iacovetta, Paula Draper, and Robert Ventresca. Toronto; Buffalo: University of Toronto Press, 1998.

Ingram, Philip. "Protestant Patriarchy and the Catholic Priesthood in Nineteenth Century England.” Journal of Social History 24, no. 4 (Summer, 1991): 783-97.

Jackson, Pauline. "Women in 19th Century Irish Emigration." The International Migration Review 18, no. 4, Special Issue: Women in Migration (Winter 1984): 1004-20.

Jasanoff, Maya. "The Other Side of Revolution: Loyalists in the British Empire." The William and Mary Quarterly, Third Series 65, no. 2 (April 2008): 205-32.

Jean, Marguerite. “TAVERNIER, ÉMILIE.” In Dictionary of Canadian Biography, Vol. 8 (Toronto; Québec: University of Toronto/Université Laval, 2003, http://www.biographi.ca/en/bio/tavernier_emilie_8E.html.

Johansen, Bruce Elliott, and Barbara Alice Mann, eds. Encyclopedia of the Haudenosaunee (Iroquois Confederacy). Westport, Conn.: Greenwood Press, 2000.

Johnson, J.K. In Duty Bound: Men, Women, and the State in Upper Canada, 1783-1841. Montreal: McGill-Queen's University Press, 2014.

Johnson, J.K., and P. B. Waite, "MACDONALD, Sir JOHN ALEXANDER." In Dictionary of Canadian Biography, Vol. 12. Toronto; Québec: University of Toronto/Université Laval, 2003-, http://www.biographi.ca/en/bio/macdonald_john_alexander_12E.html.

Johnson, Leo. "The Political Economy of Ontario Women in the Nineteenth Century." In Women at Work: Ontario 1850-1930, edited by Janice Acton, Penny Goldsmith, and Bonnie Shepard, 13-31. Toronto: Canadian Women's Educational Press, 1974.

Jones, Robert Leslie. History of Agriculture in Ontario, 1613-1880. Toronto: University of Toronto Press, 1946.

Kallmann, Helmut. "NORDHEIMER, ABRAHAM.” In Dictionary of Canadian Biography, vol. 9, University of Toronto/Université Laval, 2003-, accessed August 8, 2018, http://www.biographi.ca/en/bio/nordheimer_abraham_9E.html. 
Kaveny, M. Cathleen. "Billable Hours and Ordinary Time: A Theological Critique of the Instrumentalization of Time in Professional Life." Loyola University of Chicago Law Journal 33, no.1 (2001): 173-220.

Kelly, Kevin. "The Irish in the Empire.” In Ireland and the British Empire, edited by Kevin Kelly, 90-122. Oxford; New York: Oxford University Press, 2004.

Kenny, Stephen. "A Prejudice that Rarely Utters Its Name: A Historiographical and Historical Reflection upon North American Anti-Catholicism." American Review of Canadian Studies 32, no. 4 (2002): 639-72.

Keogh, A. "The Codification of the Canon Law." Journal of Comparative Legislation and International Law 10, no. 1 (1928): 14-32.

Kertzer, David I. The Pope Who Would be King: The Exile of Pius IX and the Emergence of Modern Europe. New York: Random House, 2018.

Kinealy, Christine. Repeal and Revolution: 1848 in Ireland. Manchester: Manchester University Press, 2009.

King, Jason. "Ireland and Canada." In Ireland and the Americas: Culture, Politics, and History: A Multidisciplinary Encyclopedia, Volume 1, edited by Patrick Byrne, Philip Coleman, Jason King, 5-13. Santa Barbara, California: ABC CLIO Inc., 2008.

Kingon, Suzanne T. "Ulster Opposition to Catholic Emancipation, 1828-9.” Irish Historical Studies 34, no. 134 (2004): 137-55.

Knowles, Valerie. Strangers at our Gates: Canadian Immigration and Immigration Policy, 1540-2015. $4^{\text {th }}$ ed. Toronto: Dundurn, 2016.

Kuhns, Elizabeth. The Habit: A History of the Clothing of Catholic Nuns. New York: Doubleday, 2005. First published 2003 by Image Books.

Küng, Hans. The Catholic Church: A Short History. New York: Modern Library, 2003.

LaPlante, Eve. Marmee \& Louisa: The Untold Story of Louisa May Alcott and Her Mother. New York: Simon and Shuster Paperbacks, 2013.

Lambert, James. "The Face of Upper Canadian Catholicism: Culture and Metropolitanism in the Establishment of the Roman Catholic Church in Upper Canada, 1800-1825." CCHA, Historical Studies 54 (1987): 5-26.

Laidlaw, Zoë, ed. Indigenous Communities and Settler Colonialism: Land Holding, Loss 
and Survival in an Interconnected World. Houndmills, Basingstoke, Hampshire: Palgrave Macmillan, 2015.

Lemire-Marsolais, Soeur Sainte-Henriette. Histoire de la Congrégation de Notre-Dame de Montréal: Troisième partie, XIX siècle, Volume VIII: 1840-1849. Montréal: Maison-Mère de la Congrégation de Notre-Dame de Montréal, 1941.

Liedel, Leslie L. "Indomitable Nuns and an Unruly Bishop: Property Rights and the Grey Nuns' Defense Against the Arbitrary Use of Diocesan Power in NineteenthCentury Cleveland.” The Catholic Historical Review 86, 3 (July 2000): 459-79.

Livermore, J.D. "The Orange Order and the Election of 1861 in Kingston.” In To Preserve \& Defend: Essays on Kingston in the Nineteenth Century. Edited by Gerald Tulchinsky, 245-29. Montreal: McGill-Queen's University Press, 1976.

Logan, John. "The Dimensions of Gender in Nineteenth-Century Schooling." In Gender Perspectives in Nineteenth-Century Ireland, edited by Margaret Kelleher and James H. Murphy, 36-49. Dublin, Ireland; Portland, Orgeon: Irish Academic Press, 1997.

Logue, Paul, and James O'Neill. "Excavations at Bishop's Street Without: 17th Century Conflict Archaeology in Derry City." Journal of Conflict Archaeology 2, no. 1 (2006): 49-75.

Lougheed, Richard. "Anti-Catholicism Among French Canadian Protestants." Historical Papers: Canadian Society of Church History (1995): 161-80.

Love, James H. "Cultural Survival and Social Control: The Development of a Curriculum for Upper Canada's Common Schools." Histoire sociale/Social History 15, no. 30 (November 1982): 357-82.

Luddy, Maria. Women and Philanthropy in Nineteenth-Century Ireland. Cambridge, England; New York, NY, USA: Cambridge University Press, 1995.

Macdonell, J.A. A Sketch of the Life of the Honourable and Right Reverend Alexander Macdonell: Chaplain of the Glengarry Fencible or British Highland Regiment, First Catholic Bishop of Upper Canada, and a Member of the Legislative Council of the Province. Alexandria: Office of the Glengarrian, 1890.

MacDonald, Heidi. "Who Counts and Why? Nuns, Work, and the Census of Canada, 1871-2001." Social History 86 (November 2010): 369-91.

MacDougall, Heather. “'Truly Alarming': Cholera in 1832." Canadian Journal of Public Health 100, no. 5 (September/October 2009): 333-34. 
MacNaughton, Colleen. "Promoting Clean Water in Nineteenth-Century Public Policy: Professors, Preachers, and Polliwogs in Kingston, Ontario." Social History 32, no. 63 (1999): 49-61.

MacPherson, D. A. J. Women and the Orange Order: Female Activism, Diaspora and Empire in the British World, 1850-1940. Manchester: Manchester University Press, 2016.

MacRaild, Donald M. “Transnationalising "Anti-Popery”: Militant Protestant Preachers in the Nineteenth-Century Anglo-World." Journal of Religious History 39, no. 2 (June 2015): 224-43.

Magray, Mary Peckham. The Transforming Power of the Nuns: Women, Religion, and Cultural Change in Ireland, 1750-1900. New York: Oxford University Press, 1998.

Mahoney, John. The Making or Moral Theology: A Study of the Roman Catholic Tradition. Oxford: Claredon Press, 1987.

Malcolmson, Patricia E. "The Poor in Kingston, 1815-1850." In To Preserve \& Defend: Essays on Kingston in the Nineteenth Century, edited by Gerald Tulchinsky, 28197. Montreal: McGill-Queen's University Press, 1976.

Mannard, Joseph G. "Maternity... of the Spirit: Nuns and Domesticity in Antebellum America." U.S. Catholic Historian 5, no. 3/4 (1986): 305-24.

Marks, Lynn. "Indigent Committees and Ladies Benevolent Societies: Intersections of Private and Public Poor Relief in Late Nineteenth Century Small Town Ontario." Studies in Political Economy 47 (Summer 1995): 61-87.

Marquis, Greg. “The Contours of Canadian Urban Justice, 1830-1875.” Urban History Review 15, no. 3 (February 1987): 269-273.

Martel, Marcel. Canada the Good: A Short History of Vice Since 1500. Waterloo, Ontario: Wilfrid Laurier University Press, 2014.

Martin, Ged. John A. Macdonald: Canada's First Prime Minister. Toronto: Dundurn Press, 2013.

McBride, Ian. The Siege of Derry in Ulster Protestant Mythology. Dublin: Four Courts Press, 1997.

McCalla, Douglas. Consumers in the Bush: Shopping in Rural Upper Canada. Montreal: McGill-Queen's University Press, 2015.

McCauley, Bernadette. "Nuns' Stories: Writing the History of Women Religious in the 
United States." American Catholic Studies 125, no. 4 (Winter 2014): 51-68.

McDermott, Rose. The Consecrated Life: Cases, Commentary, Documents, Readings. Alexandria, VA: Canon Law Society of America, 2006.

McDonald, Neil. "Egerton Ryerson and the School as an Agent of Political Socialization." In Schooling in Transition: Readings in Canadian History of Education, edited by Sara Z. Burke and Patrice Milewski, 39-56. Toronto: University of Toronto Press, 2012.

McGowan, Mark G. Death or Canada: The Irish Famine Migration to Toronto, 1847. Ottawa: Novalis, 2009.

. "Michael Power, the Catholic Church, and the Evangelization of the First Nations Peoples of Western Upper Canada, 1841-1848." In Irish and Scottish Encounters with Indigenous Peoples: Canada, the United States, New Zealand, and Australia, edited by Graeme Morton and David A. Wilson, 195219. Montreal \& Kingston: McGill-Queen's University Press, 2013. . Michael Power: The Struggle to Build the Catholic Church on the Canadian Frontier. Montreal: McGill-Queen's University Press, 2005.

McGuinness, Margaret. Called to Serve: A History of Nuns in America. New York: New York University Press, 2013.

McInnis, R. Marvin. "Women, Work, and Childbearing: Ontario in the Second Half of the Nineteenth-Century." Social History 24, no. 48 (November 1991): 237-262.

McKenna, Katherine M.J., ed. Labourers on the Rideau Canal, 1826-1832: From Work Site to World Heritage Site. Ottawa: Borealis Press, 2008.

McLaren, Kristin. "We had no desire to be set apart: Forced Segregation of Black Students in Canada West Public Schools and Myths of British Egalitarianism." Social History/Histoire Sociale 37, no. 73 (2004): 27-50.

McLaughlin, Robert. "Irish Nationalism and Orange Unionism in Canada: A Reappraisal." Éire-Ireland 41, no. 3/4 (Fall/Winter 2006): 80-109.

McMahon, Nancy. "Les Religieuses Hospitalières de Saint Joseph and the Typhus Epidemic, Kingston, 1847-1848." CCHA, Historical Studies 58 (1991): 41-55.

McMullen, John Mercier. The History of Canada: From its First Discovery to the Present Time, Vol. 2. Brockville: McMullen, 1891, $3^{\text {rd }}$ edition. 
McNab, David T. Circles of Time: Aboriginal Land Rights and Resistance in Ontario. Waterloo, Ontario: Wilfrid Laurier University Press, 1999.

McNamara, Jo Ann Kay. Sisters in Arms: Catholic Nuns Through Two Millennia. Cambridge, Massachusetts: Harvard University Press, 1996.

Meyer, Marion E. The Jews of Kingston: A Microcosm of Canadian Jewry? Kingston: Limestone Press, 1983.

Millar, John. The Educational System of the Province of Canada. Toronto: Warwick \& Sons, 1893.

Miller, Kerby A. Emigrants and Exiles: Ireland and the Irish Exodus to North America. New York; Oxford: Oxford University Press, 1985.

Miller, J.R. "Anti-Catholic Thought in Victorian Canada." Canadian Historical Review 66, 4 (1985): 474-94.

. "Anti-Catholicism in Canada: From the British Conquest to the Great War." In Creed and Culture: The Place of English-Speaking Catholics in Canadian Society, edited by Terrence Murphy and Gerald Stortz, 25-48. Montreal: McGill-Queen's University Press, 1993.

. "Bigotry in the North Atlantic Triangle: Irish, British and American Influences on Canadian Anti-Catholicism, 1850-1900." Studies in Religion/Sciences Religieuses 16, no. 3 (1987): 289-301.

." "This saving remnant': Macdonald and the Catholic Vote in the 1891 Election." CCHA, Study Sessions 41 (1974): 33-52.

Miron, Janet. Prisons, Asylums, and the Public: Institutional Visiting in the Nineteenth Century. Toronto: University of Toronto Press, 2011.

Montigny, Edgar-André. "Families, Institutions, and the State in Late-Nineteenth Century Ontario." In Ontario since Confederation: A Reader, edited by Edgar-André Montigny and Lori Chambers, 74-93. Toronto: University of Toronto Press, 2000 .

. Foisted Upon the Government?: State Responsibilities, Family Obligations, and the Care of the Dependent Aged in Late Nineteenth-Century Ontario. Montreal, Que.: McGill-Queen's University Press, 1997.

Maurutto, Paula. Governing Charities: Church and State in Toronto's Catholic Archdiocese, 1850s-1950s. Montreal; Ithaca: McGill-Queen's University Press, 2003. 
Mika, Nick and Helma Mika. Mosaic of Kingston: An Illustrated History of the City. Belleville, Ontario: Mika Silk Screening Limited, 1969.

Mills, Hazel. “'La Charité est une Mère': Catholic Women and Poor Relief in France, 1690-1850." In Charity, Philanthropy, and Reform: From the 1690s to 1850, edited by Hugh Cunningham and Joanna Innes, 168-192. New York: St. Martin's Press, 1998.

Morgan, Cecilia. Creating Colonial Pasts: History, Memory, and Commemoration in Southern Ontario, 1860-1980. Toronto: University of Toronto Press, 2015. . Public Men and Virtuous Women: The Gendered Languages of

Religion and Politics in Upper Canada, 1791-1850. Toronto: University of Toronto Press, 1996.

Travelers Through Empire: Indigenous Voyages from Early Canada. Montreal; Kingston: McGill-Queen's University Press, 2017.

Morrow, Diane Batts. Persons of Colour and Religious at the Same Time: The Oblate Sisters of Providence, 1828-1860. Chapel Hill: University of North Carolina Press, 2002.

Nash-Chambers, Debra L. "In the Palm of God's Hand? The Irish Catholic Experience in Mid-Century Guelph.” CCHA, Historical Studies 51 (1984): 67-87.

Neatby, Hilda. “Queen's University: Town and Gown in 1877.” In To Preserve \& Defend: Essays on Kingston in the Nineteenth Century, edited by Gerald Tulchinsky, 331-41. Montreal: McGill-Queen's University Press, 1976.

Neff, Charlotte. "Pauper Apprenticeship in Early Nineteenth Century Ontario." Journal of Family History 21, no. 2 (April 1996): 144-71.

Nelson, Sioban. Say Little, Do Much: Nursing, Nuns, and Hospitals in the Nineteenth Century. Philadelphia: University of Pennsylvania Press, 2001.

Nicolson, Murray W. "Ecclesiastical Metropolitanism and the Evolution of the Catholic Archdiocese of Toronto.” Social History 15, no. 29 (May 1982): 129-56.

. “The Irish Experience in Ontario: Rural or Urban?" Urban History Review 14, no. 1 (June 1985): 37-46.

Nicolson, Murray W., and John S. Moir. "CHARBONNEL, ARMAND-FRANÇOISMARIE DE.” In Dictionary of Canadian Biography, Vol. 12. Toronto; Québec: University of Toronto/Université Laval, 2003-, http://www.biographi.ca/en/bio/charbonnel_armand_francois_marie_de_12E. html. 
Noël, Françoise. Family Life and Sociability in Upper and Lower Canada, 1780-1870: A View from Diaries and Family Correspondence. Montreal: McGill-Queen's University Press, 2003.

Noël, Janet. Along a River: The First French-Canadian Women. Toronto: University of Toronto Press, 2012.

. Review of The Congrégation de Notre-Dame, Superiors, and the Paradox of Power, 1693-1796, by Colleen Gray. The Canadian Historical Review 91, no. 1 (March 2010): 121-23. . "Sisters in Arms: Quebec Convents at the Crossroads of Empire." In $A$ Companion to Women's Military History, edited by Barton C. Hacker and Margaret Vining, 409-430. Brill Publishing: Leiden; Boston, 2012.

. Women in New France. Ottawa: Canadian Historical Association, Historical Booklet 59, 1998.

Noll, Mark A. A History of Christianity in the United States and Canada. Grand Rapids, Michigan: W.B. Eerdmans, 1992.

Norman, E. R. Anti-Catholicism in Victorian England. New York: Barnes \& Noble, 1968.

Norwich, John Julius. Absolute Monarchs: A History of the Papacy. New York: Random House, 2011.

O'Connell, Marvin R. "Ultramontanism and Dupanloup: The Compromise of 1865." Church History 53, no. 2 (June 1984): 200-17.

O’Donnell, C.M., Hugh F. "Vincent de Paul: His Life and Way." In Vincent de Paul and Louise de Marillac: Rules, Conferences, and Writings, edited by John E. Rybolt and Frances Ryan, 13-38. New York, N.Y.; Mahwah, N.J.: Paulist Press, 1995.

O’Brien, Anne. “Catholic Nuns in Transnational Mission, 1528-2015.” Journal of Global History 11, no. 3 (November 2016): 387-408.

. God's Willing Workers: Women and Religion in Australia. Sydney: University of New South Wales Press Ltd., 2005.

O'Connell, Anne. "The Deserving and Non-deserving Races: Colonial Intersections of Social Welfare History in Ontario.” Intersectionalities: A Global Journal of Social Work Analysis, Research, Polity, and Practice 2 (2013): 1-23.

Olsen, Louise P. “The Orange Order, and Its Influence on Canadian Government.” The Historian 9, no. 1 (Fall 1946): 83-98.

Olson, Sherry. "Silver and Hotcakes and Beer: Irish Montreal in the 1840s." Canadian 
Ethnic Studies 45, no. 1-2 (2013): 179-201.

Olson, Sherry, and Patricia Thornton. "The Challenge of the Irish Catholic Community in Nineteenth-Century Montreal." Social History 35, no. 70 (2002): 331-62.

Ontario Department of Public Records and Archives. Historic Ontario. Toronto: Dept. of Tourism and Information, 1967.

Osborne, Brian S. "The Cemeteries of the Midland District of Upper Canada: A Note on Mortality in a Frontier Society," Pioneer America 6, no. 1 (January 1974): 46-55. . The Rock and the Sword: A History of St. Andrew's Presbyterian Church, Kingston, Ontario. Kingston: H. Heine Press at Grass Creek, 2004.

Osborne, Brian S., and Donald Swainson. Kingston: Building on the Past for the Future. Kingston: Quarry Heritage Books, 2011.

Dom Guy-Marie Oury, OSB, Jeanne Mance and the Dream of Mr. De La Dauversiere. Translated by Sr. Sheila Boase, RHSJ. Kingston: Religious Hospitallers of St. Joseph, n.d.

Palmer, Bryan D. Working-Class Experience: The Rise and Reconstitution of Canadian Labour, 1800-1980. Toronto: Butterworths, 1983.

Pagliarini, Marie Anne. "The Pure American Woman and the Wicked Catholic Priest: An Analysis of Anti-Catholic Literature in Antebellum America." Religion and American Culture 9, no. 1 (Winter 1999): 97-128.

Paz, Denis G. Popular Anti-Catholicism in Mid-Victorian England. Stanford, California: Stanford University Press, 1992.

Pearson, Timothy. "In the Eyes of the Children this was a Miracle": Sanctity in Nineteenth-Century Quebec.” CCHA, Historical Studies, 70 (2004): 94-110.

Pentland, H. Clare. Labour and Capital in Canada, 1650-1860. Toronto: J. Lorimer, 1981.

Perin, Roberto. "French-Speaking Canada from 1840." In A Concise History of Christianity in Canada, edited by Terrence Murphy and Roberto Perin, 190-259. Toronto: Oxford University Press, 1996.

Perkins, Mary Ellen. Discover Your Heritage: A Guide to Provincial Plaques in Ontario. Toronto: Dundurn, 1989.

Peterson, Susan C. "A Widening Horizon Catholic Sisterhoods on the Northern Plains, 1874-1910.” Great Plains Quarterly 5 (Spring 1985): 125-32.

Philippart, David. "Making Ashes.” Journal of the Liturgical Conference 15, no. 1 (1998): 41-46. 
Philips, Paul, ed. Labour and Capital in Canada, 1650-1860. Toronto: James Lorimer \& Company, 1981.

Pilon, Dennis. "The Contested Origins of Canadian Democracy." Studies in Political Economy 98, no. 2 (2017): 105-23.

Poelzer, Greg, and Ken S. Coate. From Treaty Peoples to Treaty Nation: A Road Map for All Canadians. Vancouver; Toronto: UBC Press, 2015.

Potter-MacKinnon, Janice. While the Women Only Wept: Loyalist Refugee Women. Montreal, Que.: McGill-Queen's University Press, 1993.

Prentice, Alison. The School Promoters: Education and Social Class in Mid-Nineteenth Century Upper Canada. Don Mills, Ont.: Oxford University Press, 1999.

Putman, J. Harold. Egerton Ryerson and Education in Upper Canada. Toronto: W. Briggs, 1912.

Rabbani, G.H., and W.B. Greenough III. "Food as a Vehicle of Transmission of Cholera." Journal of Diarrhoeal Diseases Research 17, no. 1 (March 1999): 1-9.

Radforth, Ian Walter. Royal Spectacle: The 1860 Visit of the Prince of Wales to Canada and the United States. Toronto: University of Toronto Press, 2004.

Ralls, Walter. "The Papal Aggression of 1850: A Study in Victorian Anti-Catholicism." Church History 43, no. 2 (June 1974): 242-56.

Ranasinghe, Prashan. "'Vagrancy as a Penal Problem': The Logistics of Administering Punishment in Late-Nineteenth-Century Canada." Journal of Historical Sociology 10, no. 4 (December 1997): 531-51.

Rapley, Elizabeth. The Dévotes: Women and Church in Seventeenth-Century France. Kingston: McGill-Queen's University Press, 1990. . A Social History of the Cloister. Montreal, Quebec: McGill-Queen's University Press, 2001.

Reed, Charles V. Royal Tourists, Colonial Subjects and the Making of a British World, 1860-1911. Manchester: Manchester University Press, 2016.

Reese, Abbie. Dedicated to God: An Oral History of Cloistered Nuns. Oxford: Oxford University Press, 2014.

Reid, John G., and Elizabeth Mancke. "From Global Processes to Continental Strategies: 
The Emergence of British North America to 1783." In Canada and the British

Empire, edited by Philip Buckner, 22-42. Oxford; New York: Oxford University Press, 2008.

Reid, Richard M. African Canadians in Union Blue: Enlisting for the Cause in the Civil War. Vancouver: UBC Press, 2014.

., ed. The Upper Ottawa Valley to 1855. Ottawa: The Champlain Society and Carleton University Press, 1989.

Richter, Daniel K. The Ordeal of the Longhouse: The Peoples of the Iroquois League in the Era of European Colonization. Chapel Hill: University of North Carolina Press, 1992.

. Before the Revolution: America's Ancient Pasts. Cambridge, Mass.: Belknap Press of Harvard University Press, 2011.

Rider, Peter E., and Heather McNabb, eds. A Kingdom of the Mind: How the Scots Helped Make Canada. Montreal; Ithaca: McGill-Queen's University Press, 2006.

Ripmeester, Michael. "'It is scarcely to be believed...': The Mississauga Indians and the Grape Island Mission, 1826-1836." The Canadian Geographer 39, no. 2 (1995): $157-68$.

Ritchie, Elizabeth. "Cows, Sheep \& Scots: Livestock and Immigrant Strategies in Rural Upper Canada, 1814-1851," Ontario History 109, no. 1 (Spring 2017): 1-26.

Rives, Danielle. "Taking the Veil: Clothing and the Transformation of Identity." Translated by Carol E. Harrison. Journal of the Western Society for French History 33 (2005): 465-86.

Roberts, David A. "The Orange Order in Ireland: A Religious Institution?” The British Journal of Sociology 22, no. 3 (September 1971): 269-82.

Roberts, Julia. In Mixed Company: Taverns and Public Life in Upper Canada. Vancouver: UBC Press, 2009.

Rogers, Edward S., and Donald B. Smith, eds. Aboriginal Ontario: Historical Perspectives on the First Nations. Toronto: Dundurn Press, 1994.

Rogers, Rebecca. From the Salon to the Schoolroom: Educating Bourgeois Girls in Nineteenth-Century France. University Park, Pa.: Pennsylvania State University Press, 2005.

Romney, Paul. "Upper Canada (Ontario): The Administration of Justice, 1784-1850.” 
Manitoba Law Journal 23 (1995): 183-213.

Rooke, Patricia T., and R.L. Schnell. "Childhood and Charity in Nineteenth-Century British North America," Social History 15, no. 29 (May 1982): 157-79. . Discarding the Asylum: From Child Rescue to the Welfare State in English-Canada (1800-1950). Lanham, MD: University Press of America, 1983. . "The Rise and Decline of British North American Protestant Orphans' Home as Woman's Domain, 1850-1930." Atlantis 7, no. 2 (Spring 1982): 21-35.

Rosenberg, Carroll-Smith. "The Female World of Love and Ritual: Relations Between Women in Nineteenth-Century America." In Disorderly Conduct: Visions of Gender in Victorian America, 53-76. New York: A. A. Knopf, 1985.

Rousseau, Louis. "QUIBLIER, JOSEPH-VINCENT », dans Dictionnaire biographique $d u$ Canada, vol. 8. Toronto; Québec: Université Laval/University of Toronto, 2003-, http://www.biographi.ca/fr/bio/quiblier_joseph_vincent_8F.html.

Roy, James A. Kingston: The King's Town. Toronto: McClelland \& Stewart, 1952.

Sack, B. J. History of the Jews in Canada. Montréal: Harvest House, 1965.

Sager, Eric W. "The Transformation of the Canadian Domestic Servant, 1871-1931," Social Science History 31, no. 4 (Winter 2007): 509-37.

Saint-Henriette, Soeur, and Thérèse Lambert. Histoire de la Congrégation de NotreDame de Montréal. Montréal: Maison-Mère de la Congrégation de Notre-Dame de Montréal, 1941.

Sanders, S.M. "Charisms, Congregational Sponsors, and Catholic Higher Education," Journal of Catholic Higher Education 29, no. 1 (2010): 3-18.

Schneiders, Sandra M. Selling All: Commitment, Consecrated Celibacy, and Community in Catholic Religious Life. New York, N.Y.; Mahwah, N.J.: Paulist Press, 2001.

Schuck, Michael Joseph. That They Be One: The Social Teaching of the Papal Encyclicals, 1740-1989. Washington, D.C.: Georgetown University Press, 1991.

Schultz, Nancy Lusignan. Fire \& Roses: The Burning of the Charlestown Convent, 1834. Boston: Northeastern University Press, 2000.

Scott, Joan Wallach. Sex and Secularism. Princeton: Princeton University Press, 2018.

Senior, Elinor. "The Provincial Calvary in Lower Canada, 1837-50." The Canadian Historical Review 57 no. 1 (March 1976): 1-24. 
Shaw, Richard. John Dubois: Founding Father, The Life and Times of the Founder of Mount St. Mary's College, Emmitsburg; Superior of the Sisters of Charity; and Third Bishop of the Diocese of New York. Yonkers, New York: United States Catholic Historical Society, 1983.

Shoemaker, Robert B. Gender in English Society 1650-1850: The Emergence of Separate Spheres? London: Routledge, 2014.

Simpson, Patricia. Marguerite Bourgeoys and the Congregation of Notre-Dame, 1665 1700. Montreal; Ithaca: McGill-Queen's University Press, 2005. . Marguerite Bourgeoys and Montreal, 1640-1665. Montréal: McGillQueen's University Press, 1997.

Sirven, Joseph I., et al. "Seizures Among Public Figures: Lessons Learned from the Epilepsy of Pope Pius IX.” Mayo Clinic Proceedings 82, no. 12 (December 2007): 1535-40.

Slattery, Maureen. "Irish Radicalism and the Roman Catholic Church in Quebec and Ireland, 1833-1834: O'Callaghan and O'Connell Compared." CCHA, Historical Studies 63 (1997): 29-58.

Smallman-Raynor, M. R., and A.D. Cliff. War Epidemics: An Historical Geography of Infectious Diseases in Military Conflict and Civil Strife, 1850-2000. New York: Oxford University Press, 2004.

Smandych, Russell. "Colonial Welfare Laws and Practices: Coping without an English Poor Law in Upper Canada, 1792-1837.” Manitoba Law Journal 23 (1995): 21446.

Smyth, Elizabeth. "Professionalization Among the Professed: The Case of Roman Catholic Religious." In Challenging Professions: Historical and Contemporary Perspectives on Women's Professional Work, edited by Elizabeth Smyth, Sandra Acker, Paula Bourne and Alison Prentice, 234-54. Toronto, University of Toronto Press: 1999. , ed. Changing Habits: Women Religious in Canada. Ottawa: Novalis, 2007.

. "Leading Congregations: Transforming Society, Catherine McKinley, Sister of Providence of St Vincent de Paul." History of Education Researcher 80 (2007): 122-135.

. "A Tale of Two Sister-Principals: Mother Mary Edward (Catherine) 
McKinley, Sisters of Providence of St. Vincent de Paul (Kingston, ON) and Mother Mary of Providence (Catherine) Horan, Sisters of Providence of Holyoke, MA." Encounters in Theory and History of Education 14 (2013): 119-132.

. "World Within Worlds: Canadian Women Religious, International Connections, Ecclesiastical Webs and the Secular State." In Women Educators, Leaders and Activists: Educational Lives and Networks 1900-1960, edited by Tanya Fitzgerald and Elizabeth M. Smyth, 41-57. London: Palgrave MacMillan, 2014.

Smyth, William J. Toronto, the Belfast of Canada: The Orange Order and the Shaping of Municipal Culture. Toronto: University of Toronto Press, 2015.

Splane, Richard B. Social Welfare in Ontario, 1791-1893: A Study of Public Welfare Administration. Toronto: University of Toronto Press, 1965.

Stamp, Robert. The Historical Background to Separate Schools in Ontario (Toronto: Queen's Park; Ministries of Colleges and Universities, 1985.

Stanworth, Karen. Visibly Canadian: Imaging Collective Identities in the Canadas, 18201910. Montreal \& Kingston: McGill-Queen's University Press, 2014.

Stewart, Stormie. "The Elderly Poor in Rural Ontario: Inmates of the Wellington County House of Industry, 1877-1907." Journal of the Canadian Historical Association 3, no. 1 (1992): 217-233.

Strong-Boag, Veronica. Finding Families, Finding Ourselves: English Canada Encounters Adoption from the Nineteenth Century to the 1990s. Don Mills, Ont.: Oxford University Press, 2006.

Sullivan, Rebecca. Visual Habits: Nuns, Feminism, and American Postwar Popular Culture (Toronto: University of Toronto Press, 2005.

. "A Wayward from the Wilderness: Maria Monk's Awful Disclosures and the Feminization of Lower Canada in the Nineteenth Century." Essays on Canadian Writing 62 (Fall 1997): 201-22.

Swenson, Don. "Religious Differences between Married and Celibate Clergy: Does Celibacy Make a Difference?" Sociology of Religion 59, no. 1 (Spring 1998): 3743.

Sylvain, Philippe. "BOURGET, IGNACE.” In Dictionary of Canadian Biography, Vol. 11. Toronto; Québec: University of Toronto/Université Laval, 2003, http://www.biographi.ca/en/bio/bourget_ignace_11E.html.

. "Ignace Bourget." The Canadian Encyclopedia. Toronto: Historica 
Canada, 1985-, https://www.thecanadianencyclopedia.ca/en/article/ignacebourget/.

. "MONK, MARIA." In Dictionary of Canadian Biography, vol. 7.

Toronto; Québec: University of Toronto/Université Laval, 2003-, 2018, http://www.biographi.ca/en/bio/monk_maria_7E.html.

Taylor, Alan. The Divided Ground: Indians, Settlers, and the Northern Borderland of the American Revolution. New York: Vintage Books, 2007.

Thériault, Michel. The Institutes of Consecrated Life in Canada From the Beginning of New France up to the Present: Historical Notes and References. Ottawa: National Library of Canada, 1980.

Thompson, Margaret Susan. "Sisterhood and Power: Class, Culture, and Ethnicity in the American Convent." Colby Library Quarterly 25, no. 3 (September 1989): 14975.

Tickle, Phyllis. The Divine Hours, Vol. II: Prayers for Autumn and Wintertime. New York: Doubleday: 2000.

Titley, Brian E. Into Silence and Servitude: How American Girls Became Nuns, 1945 1965 (Montreal; Kingston: McGill-Queen's University Press, 2017).

Trigger, Rosalyn. "Clerical Containment of Diasporic Irish Nationalism: A Canadian Example from the Parnell Era." In Irish Nationalism in Canada, edited by David A. Wilson, 83-96. Montreal; Kingston: McGill-Queen's University Press, 2009.

. "Irish Politics on Parade: The Clergy, National Societies, and St. Patrick's Day Processions in Nineteenth-Century Montreal and Toronto." Social History 37, no. 74 (2004): 159-99.

Tobin, Jacqueline, and Hettie Jones. From Midnight to Dawn: The Last Tracks of the Underground Railroad. New York: Anchor Books, 2008.

Tosh, John. A Man's Place: Masculinity in the Middle-Class Home in Victorian England. New Haven: Yale University Press, 1999.

Truth and Reconciliation Commission. Canada's Residential Schools: The History, Part 1: Origins to 1939: The Final Report of the Truth and Reconciliation Commission of Canada, Vol. 1. Montreal \& Kingston: McGill-Queen's University Press, 2015.

They Came for the Children: Canada, Aboriginal Peoples, and Residential Schools. Winnipeg, Man.: Truth and Reconciliation Commission of Canada, 2012; Saint-Lazare, Quebec: Canadian Electronic Library, 2012.

Underhill, Frank H. "The Development of National Political Parties in Canada." 
Canadian Historical Review 16, no. 4 (December 1935): 367-87.

Valverde, Mariana. “The Mixed Social Economy as a Canadian Tradition.” Studies in Political Economy 47 (Summer 1995): 33-60.

Van Die, Marguerite. "Revisiting "Separate Spheres": Women, Religion, and the Family in Mid-Victorian Brantford, Ontario." In Households of Faith: Family, Gender and Community in Canada, 1760-1969, edited by Nancy Christie, 234-63. Montréal, Que.: McGill-Queen's University Press, 2002.

Verhoeven, Timothy. "Harmful or Benign? Transnational Medical Networks and the Celibacy of Priests." Journal of Religious History 39, no. 2 (June 2015): 244-60.

Vertovec, Steven. Transnationalism. London; New York: Routledge, 2009.

Walker, Brian. "1641, 1689, 1690 and All That: The Unionist Sense of History." The Irish Review, no. 12 (Spring-Summer 1992): 56-64.

Walsh, Michael. The Cardinals: Thirteen Centuries of the Men Behind the Papal Throne. Grand Rapids, Michigan; Cambridge, United Kingdom: William B. Eerdmans Publishing Company, 2010.

Wamsley, Kevin B., and Robert S. Kossuth. "Fighting It Out in Nineteenth-Century Upper Canada/Canada West: Masculinities and Physical Challenges in the Tavern." Journal of Sport History 27, no. 3 (Fall 2000): 405-30.

Ward, Peter W. Courtship, Love and Marriage in Nineteenth-Century English Canada. Montréal: McGill-Queen's University Press, 1990.

Wcela, Emil A. What is Catholic about a Catholic Translation of the Bible? The Catholic Biblical Quarterly, 71 no. 2 (Apr. 2009): 247-263.

Wherrett, George Jasper. The Miracle of the Empty Beds: A History of Tuberculosis in Canada. Toronto: University of Toronto Press, 1977.

Williams, Shannen Dee. "Forgotten Habits, Lost Vocations: Black Nuns, Contested Memories, and the $19^{\text {th }}$ Century Struggle to Desegregate U.S. Religious Life." Journal of African American History, 101 (Summer 2016): 231-260. 2016): 14-21.

. "The Color of Christ's Brides." American Catholic Studies, 127 (Fall

Wilson, Catharine Anne. Tenants in Time: Family Strategies, Land, and Liberalism in Upper Canada, 1799-1871. Montreal: McGill-Queen's University Press, 2009.

Wilton, Carol. Popular Politics and Political Culture: 1800-1850. Montreal: McGillQueen's University Press, 2000. 
Wittberg, Patricia. From Piety to Professionalism - and Back?: Transformations of Organized Religious Virtuosity. Lanham, MD: Lexington Books, 2006.

"Non-Ordained Workers in the Catholic Church: Power and Mobility Among American Nuns." Journal for the Scientific Study of Religion 28, 2 (June 1989): 148-161.

Wolffe, John. “Anti-Catholicism and the British Empire, 1815-1914.” In Empires of Religion, edited by Hilary M. Carey, 43-63. Basingstoke, England; New York: Palgrave Macmillan, 2008.

Yacovazzi, Cassandra L. "Are You Allowed to Read the Bible in a Convent?": Protestant Perspectives on the Catholic Approach to Scripture in Convent Narratives, 1830-1860." U.S. Catholic Historian 31, no. 3 (Summer 2013): 2346.

Yee, Shirley J. “Gender Ideology and Black Women as Community-Builders in Ontario, 1850-70." Canadian Historical Review 75, no. 1 (March 1994): 53-73. 